\title{
Final \\ Report
}

Energy Conserving Site

Design Case Study

Burke Center, Virginia

Prepared for:

U.S. Department of Energy

Assistant Secretary for Conservation and

Solar Energy

Office of Buildings and

Community Systems

Washington, D.C. 20545 


\section{DISCLAIMER}

This report was prepared as an account of work sponsored by an agency of the United States Government. Neither the United States Government nor any agency Thereof, nor any of their employees, makes any warranty, express or implied, or assumes any legal liability or responsibility for the accuracy, completeness, or usefulness of any information, apparatus, product, or process disclosed, or represents that its use would not infringe privately owned rights. Reference herein to any specific commercial product, process, or service by trade name, trademark, manufacturer, or otherwise does not necessarily constitute or imply its endorsement, recommendation, or favoring by the United States Government or any agency thereof. The views and opinions of authors expressed herein do not necessarily state or reflect those of the United States Government or any agency thereof. 


\section{DISCLAIMER}

Portions of this document may be illegible in electronic image products. Images are produced from the best available original document. 


\section{NOTICE}

This report was prepared as an account of work sponsored by the United States Goverrment. Neither the United States nor the United States Department of Energy, nor any of their employees, makes any warranty, express or implied, or assumes any legal liability or responsibility for the accuracy, completeness, or usefulness of any information, apparatus, product. or process disclosed, or represents that its use would not infringe privately owned rights. Reference herein to any specific commercial product, process, or service by trade name, mark, manufacturer, or otherwise, does not necessarily constitute or imply its endorsement, recommendation, or favoring by the Jnited States Government or any agency thereof. The views and opirions of authors expressed herein do not necessarily state or reflect those of the United States Government or any agency thereof. 


\section{Final}

\section{Report}

\section{Energy Conserving Site Design Case Study Burke Center, Virginia}

\section{December 1979}

Prepared by:

Land Design/Research, Inc.

$\checkmark$ Columbia, Md. 21044

with the assistance of:

James Wannemacher \& Associates, Inc.

Hittman Associates, inc. \&

Dewberry, Nealon and Davis

Prepared for:

U.S. Department of Energy

Assistant Secretary for Conservation and Solar Energy

Office of Buildings and Community Systems

Washington, D.C. 20545

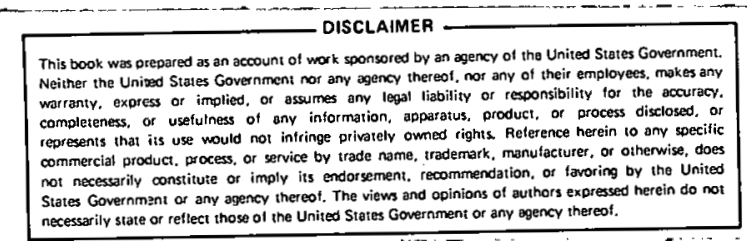


Table of Contents

Pagé

Introduction

Section 1 Study Summary

Executive Summary

Fairfax County

Burke Centre

The Developer

The Study

Fairfax County Policy

Electric Service

Marketing Considerations

\section{Section 2 The Study Parcels}

The Town Center Parcels $21 \& 23$

Parcel 22 (Garden Apts. \& Townhouses)

The Neighborhood Center

Residential Parcels 12B, 12C, and 24 A \& B

\section{Section 3 Developing The Energy Conserving Plan}

Introduction: Inventory of Base Plan

Base Plan Analysis (Site \& Building Data)

Base Plan Analysis (Site)

Energy Profile for Base Plan $\quad \cdots$

Engineering Analysis

Space Conditioning

Water Energy Use

Solid Waste

Transportation

Energy Options and Screening Methodology

Options Incorporated Into Plan

Failed Options

Energy Conserving Applications

Off-Site Transportation

On-Site Transportation

Heating \& Cooling

Water Saving Devices

Hot Water Usage

Solid Waste Removal

Site Planning Techniques

Topo \& Orientation

Clustering

Pavement Design

Utilities

Community Services

Site Specific

Building Modifications 


\section{List of Figures}

No. Title

Page

1. Regional Context Map

2. Metropolitan Area

3. Fairfax County.

4. Burke Centre Development Plan

5. Base Plan of Study Area

6. Base Plan - Town Center

7. Base Plan - Parcel 22

8. Base Plan of Study Area

9. Energy Conserving Plan of Study Area

10. Base Plan - Existing Vegetation Retained

11. A-F Climatological Data

12. Elevation Study

13. Site Analysis

14. Base Plan - Solar Impact - Winter

15. Base Plan - Solar Impact - Summer

16 Base Plan - Winter Shade

17. Base Plan - Summer Shade :

18. Base Plan - Prevailing Winter Winds 27

19. Base Plan - Summer Breezes. 27

20. Base Plan - Traffic Patterns . 28

21. Base Plan - Impervious Cover ' - 28

22. Building Data for Energy Profile 30

23. Base Plan - Annual Energy Use 32

24. Pathway System 43

25. Water to Air Heat Pump $\quad 44$

26. A-C Roadway \& Paving 46

27. Site Development - Town Center $\quad 46$

28. Cluster Plan for Town Center 47

29. A-D Parking Concepts 48

30. A-D Site Planning \& Building Orientation 49

31. A-F Site Planning for Neighborhood Center 50

32. Energy Plan - Existing Vegetation Retained 53

33. Energy Plan - Solar Impact - Summer . 54

34. Energy Plan - Solar Impact - Winter 55

35. Energy Plan - Prevailing Winter Winds 56

36. Energy Plan • Summer Breezes 57

37. Energy Plan - Summer Shade 58

38. Energy Plan - Traffic Patterns 58

39. Energy Plan - Winter Shade 58

40. Energy Plan - Impervious Cover 58

41. Base Plan • Annual Energy Use . . 59

42. Energy Plan • Annual Energy Use 59 


\section{List of Tables}

No.

Title

Page

1A. Energy Use Index

1. Base Plan Total Energy Per Commercial/Recreation Type.

2. E/C Plan Total Energy Per Commercial/Recreation Type.

3. Reductions in Fuel Use From the Use of Human

Transportation in Parcels 21/23 (Town Center). 14

4. Site Development Costs • Town Center 14

5. Base Plan • Space Conditioning Equipment Costs.

6. E/C Plan • Space Conditioning Equipment Costs. 15

7. E/C Plan - Associated Well and Piping Costs. 16

8A. Site Development Costs - Parcel 22 18

8. Site Development Costs - Neighborhood Center 19

9. Base Plan - Annual Energy Use. 32

10. Base Plan - Total Energy Use of Buildings. 33

11. Base Plan • Energy Use Per Average Residential Unit. 33

12. Base Plan • Total Energy Use Per Residential Type. 34

13. Base Plan - Total Energy Per Commercial/Recreation 34

14. Base Plan • Energy Use Per Parcel 35

15. Base Plan - Space Conditioning Equipment Costs. 35

16. Base Plan • Annual Water, Hot Water \& Waste Water
Demand and Energy Use.

17. Base Plan. Annual Solid Waste Collection and
Transportation Energy Use.

18. Average Trip Lengths. 37

19. Total Transportation Energy Use • Residential.

20. Total Transportation Energy Use • Commercial 38

21. Transportation Energy Analysis - Base Plan. 38

22. Energy Conservation Options That Survived the

23. Energy Conservation Options That Failed the Screening
Process.

24. Annual Water Usage and Waste Water Treatment
Requirements By Parcel.

25. Plan Evaluations - By Parcel 52

26. Base Plan • Energy Use 59

27. Energy Plan • Energy Use 59 
Development patterns and land planning practices in this country have proceeded for several decades on the presumption ihat gasoline and electricity would continue to be available at bargain prices. Highways, rather than transit lines, have become the connectors between residential neighborhoods and employment centers. Convenience goods and services are consigned to strips along arterials, most often at the very fringe of their market area. Mass retailing and tract housing dominate the development industry. Water and sewer systems determine the direction and pace of suburban growth. Zoning laws segregate land uses while subdivision regulations standardize most of the creativity out of neighborhood planning. Until the initial gasoline shortages of the early 1970 's, little attention was given to the amount or type of energy that would be needed to support the community structures that were evolving.

It is not surprising to learn that the average American family consumes enormous amounts of energy carrying out its daily routines. Transportation costs eat up nearly 70 percent of the family's energy budget. The typical "local" trip for work or shopping is in excess of five miles and, because the automobile is the only convenient way to get most places, the routes are so congested that gasoline efficiency is severly impaired. The decentralization of commercial and public facilities combined with large lot, low density subdivisions add additional driving time at each end of a typical trip.

Although only 30 percent of a community's energy use is associated with the operation of homes and commercial space, the amount of waste is still substantial. The siting and configuration of most structures ignore the impact of sun and winds and the long-understood techniques for cooperating with nature. Mechanical systems within structures waste much of the energy they consume. Potable water is treated as a natural resource with little regard for the electric loads needed to purify it and to treat the resultant waste leaving the home.

Building today to conserve energy tomorrow is not a simple proposition. Available knowledge and technology is sufficient, if applied, to make our communities substantially more energy efficient. The obstacles lie with the expectations and lifestyles of the consumer and the practices of the building industry and public officials that have emerged in response to the public's demands. In this report we examine the pattern of energy consumption within a

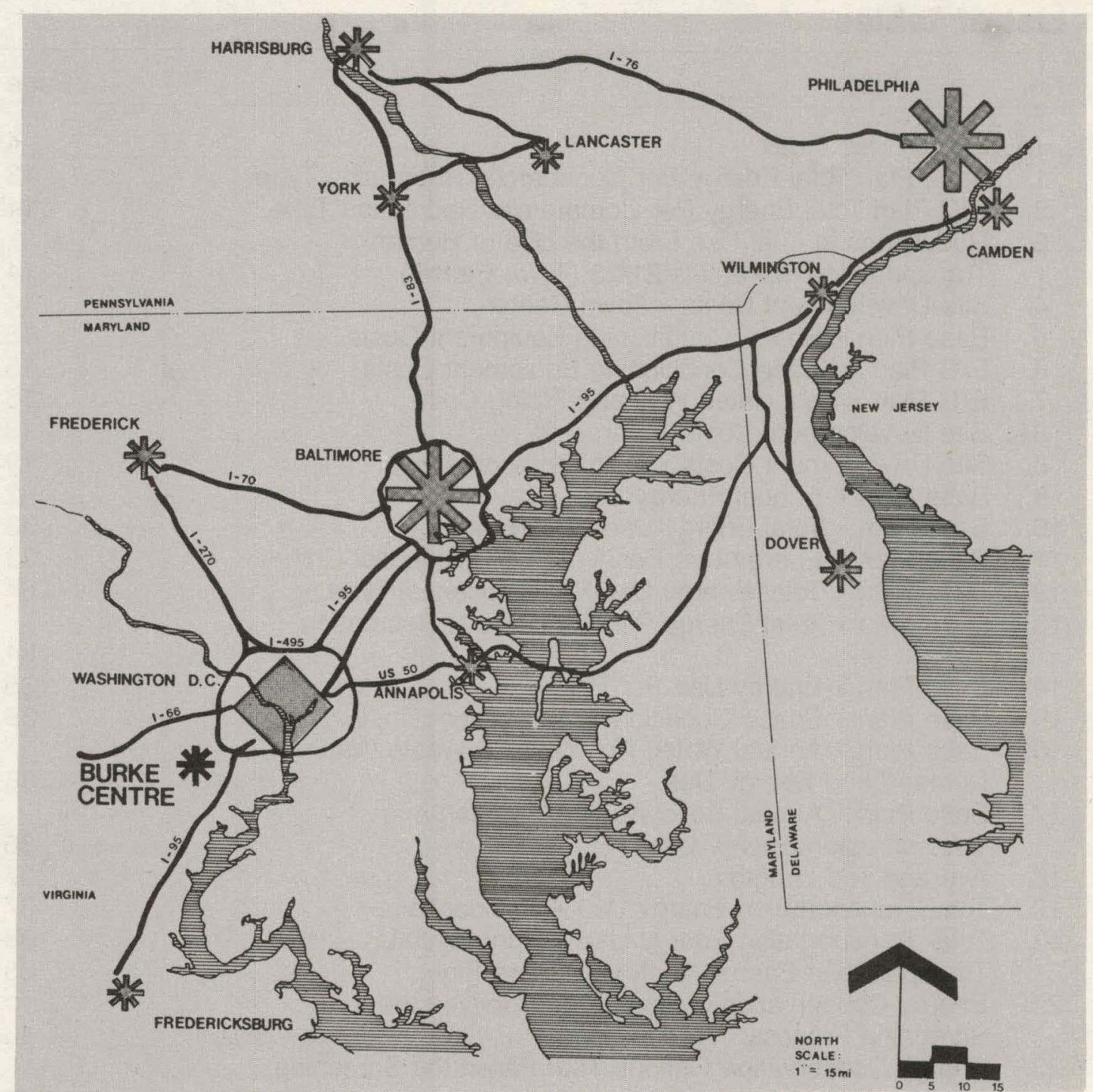

Figure 1. Regional Context Map

modern suburban community. Based on these observations we then propose a variety of actions that could be incorporated to reduce its future energy demands. We have limited our recommendations to those that are technically feasible today, are reasonably cost-effective and that should generate little or no market resistance. If implemented as proposed, land development costs could be reduced by as much as 18 percent, while yielding the same densities. The added costs for the proposed heating and cooling systems would be returned in two years. Total energy consumption by the buildings in the community would come down by at least 33 percent. There should be no negative impact on either the price of homes or on

We chose as our test case a new planned community, Burke Centre, located within Fairfax County, Virginia. This happens to be Washington, D.C.'s fastest growing suburban area and its wealthiest as well. Fairfax residents live by the car and, at least until now, could afford the cost of an hour's commute to work and the privileges of low density neighborhoods free of commercial and other non-residential uses. The developer of Burke Centre cooperated fully with our exploration of energy efficient programs. His experience and knowledge of the development process and the Fairfax market kept our efforts within the context of what can be achieved by the building industry today. 
OF THE TOTAL ENERGY CONSUMED BY THE BURKE CENTRE COMMUNITY, 57 PERCENT WILL GO TO OFF-SITE TRANSPORTATION NEEDS.

Burke Centre, like most residential suburbs, depends on its parent city, Washington, D.C., for employment and many retail, cultural and recreationa needs. The lack of adequate mass transit means that most of these trips, averaging over seven miles in length, will be made by automobile.
First, we have proposed the institution of a park-and-ride system using a section of the Town Center parking lot when it is constructed. We estimate that 2.5 percent of the total residential transportation energy use of the community could be saved by utilizing a coordinated bus service to Washington and other key employment centers. This program has been well received by both the developer and the County officials.

Second, on a longer-range basis the County and the community should pursue the expansion of local bus service connecting the Town Center with other commercial centers and with the residential neighborhoods of the area. The Town Center has a potential market area extending up to ten miles and will therefore be a major trip generator within the region. A publically subsidized local bus shuttle service, such as provided in Montgomery County, Maryland, would reduce off-site transportation energy use.

Third, on a long-range basis, the County and area residents should explore the use of the existing Southern Rail line as a commuter service to the Washington area. This prospect has received some attention in the past. If implemented, it would be the largest contributor to reducing energy consumed for off-site travel.

Fourth, the County should consider pursuing an aggressive employment program for its heavily populated sections, such as the Burke Centre area. Bedroom communities are high energy consumers regardless of available transit systems. Total suburban communities like Columbia, Maryland that integrate employment with housing have the greatest potential for energy savings in the future.

Fifth, the recommendation was made to the County that the Town Center be considered for future expansion into as broad an activity area as possible. Since the Center is intended to have a sub-regional draw, the more needs that can be served at that one location the greater the potential for energy conservation.

\section{Recommendations}

First, local zoning and subdivision controls should encourage flexible site planning by providing real incentives for retaining natural features and for properly orienting structures.

Second, development standards such as road widths and parking requirements should be seriously reviewed to insure they have not become over-designed for today's needs.

Third, the direct relationship between cost effective site planning and future energy savings, as portrayed in this study, should be broadly disseminated to the development industry and local public officials. This is one of the few areas where cost savings are associated with the reduction of energy consumption.

\section{Finding}

WATER-TO-AIR HEAT PUMPS PROVED TO BE THE MOST EFFICIENT AND COST EFFECTIVE METHOD AVAILABLE TODAY IN THE BURKE CENTER STUDY AREA FOR REDUCING HEATING AND COOLING COSTS IN BUILDINGS.

We calculated a reduction of the total heating and cooling energy consumption of 44 percent for our combined study areas at a cost that is retrievable within two years. About 90 percent of the energy reduction is attributable to the use of the water-to-air system; about 10 percent is due to passive and other building modifications.

\section{Recommendations}

First, water-to-air systems can use ground water, if available, or they can operate on self-contained storage systems. Since the former is often the cheaper of the two, developers and public agencies should investigate the availability of adequate and suitable ground water prior to development.

Second, research should be conducted into the creation of water storage systems such as in natural aquifers. The availability of ample water for heat pump operations can reduce the cost to the developer and make the system economically feasible over a broader part of the country. 


\section{Finding}

CERTAIN PUBLIC SERVICES SUCH AS THE COLLECTION OF SOLID WASTE, MAIL PICK-UP AND DELIVERY, AND OTHER ROUTINE ACTIVITIES CAN BE MADE MORE ENERGY EFFICIENT.

In our study we analyzed one of these functions, that of solid waste collection. We found that the total trips associated with this activity could be reduced by up to 40 percent with the use of more efficient packer trucks.

\section{Finding}

THE USE OF AVAILABLE WATER SAVING DEVICES IN RESIDENTIAL AND COMMERCIAL BUILDINGS CAN REDUCE A COMMUNITY'S TOTAL UTILITY ENERGY CONSUMPTION BY AS MUCH AS 20 PERCENT.

We found that the use of flow restrictors, mixing valves, low volume flush toilets and water conserving appliances can cut total water consumption by 42 percent. The treatment of potable and waste water consumes 24 percent of all community energy supplied by the utility company, or a savings in water energy use of 43 percent. The reduction in hot water energy consumption is equally significant. Hot water production consumes 22 percent of the energy delivered by the utility. The use of the devices studied reduces hot water usage by 44 percent.

\section{Summary}

The energy conserving plan shows a $20 \%$ reduction in primary energy consumption over the base plan. The Energy Use Index of the buildings for the total study area of the energy conserving plan shows a $33 \%$ reduction in BTU/square foot/year over the base plan.

\section{Recommendations}

First, public officials associated with the provision of services to low and medium density areas such as Burke Centre should consider the cost-benefit margins of utilizing equipment and systems that reduce the number of vehicular trips.

Second, the support of research and development in this field by agencies such as the Department of Energy may produce handsome results.

\section{Recommendations}

First, builders can play an important role in educating the homebuyer to the advantages of installing water saving devices in his new residence.

Second, communities should consider making certain devices mandatory in new homes while encouraging the use of those that are less cost efficient but still important conservers of water.

Third, the support of further research and development in the field of water conservation in the home promises substantial benefits in terms of energy savings.

\begin{tabular}{l} 
Table 1A. Energy Use Index* \\
\hline
\end{tabular}

*Includes HVAC equipment, appliances, lighting, hot water heating, and pumping energy uses. 


\section{Fairfax County}

The proximity of Fairfax County to Washington is the prime cause of both the growth and the stability of its economic base. The federal government, military, and private sector businesses who deal with the government have traditionally been the County's largest employers. As of the 1970 census the three predominent occupations were professional-technical, clerical, and managers-administrators, comprising $67 \%$ of the work force. Although service and light industry sectors are both increasing, the federal influence remains strong, and the stability of government related employment has proven to be the determinent of growth.

Median family income continues to be one of the highest in the nation. In 1970, family income was $\$ 15,707$ in Fairfax County, $\$ 16,710$ in Montgomery County, Maryland, and $\$ 12,933$ for the entire Washington Standard Metropolitan Statistical Area (SMSA). Estimates for October 1974 show Fairfax at $\$ 21,000$ (up 33.7\%), Montgomery at $\$ 21,400$ (up $28 \%$ ) and the SMSA at $\$ 16,900$ (up $30.7 \%$ ), indicating the continued economic growth of the region, and Fairfax County in particular.

The Washington SMSA has grown steadily since 1950 with Fairfax County growing faster than the region as a whole. During the decade of the 50's the County grew by $153 \%$. During the 60 's Fairfax grew at twice the rate of the Metropolitan area adding over 206,000 persons at an annual rate in excess of $6 \%$. Since 1970 , the County has added 144,725 to its population at an annual rate of $3.5 \%$. The 1979 estimated population is 599,000 , and current projections indicate a 1990 population of 780,000 , and a 2000 population of 949,800 .

Fairfax has grown at an extremely rapid rate, with high family income. The Pohick area was the focus of much of this growth in the late 1960's and continues today. The current Pohick area is 57,245 . It is estimated that an additional 12,000 people will live in the Pohick area by 1990. Most development in the Pohick has been in the form of single family detached homes with townhouses becoming more popular in recent years. The existing housing inventory consists of approximately 10,600 units, $75 \%$ being single family. Due to both its proximity to Washington and the extensive open space system nearby, the average sales price in the Pohick for a single family detached home in January 1974 was $\$ 60,300$; for a townhouse, $\$ 41,600$. There are approximately 2700 additional units committed (either under construction or with building permits issued)

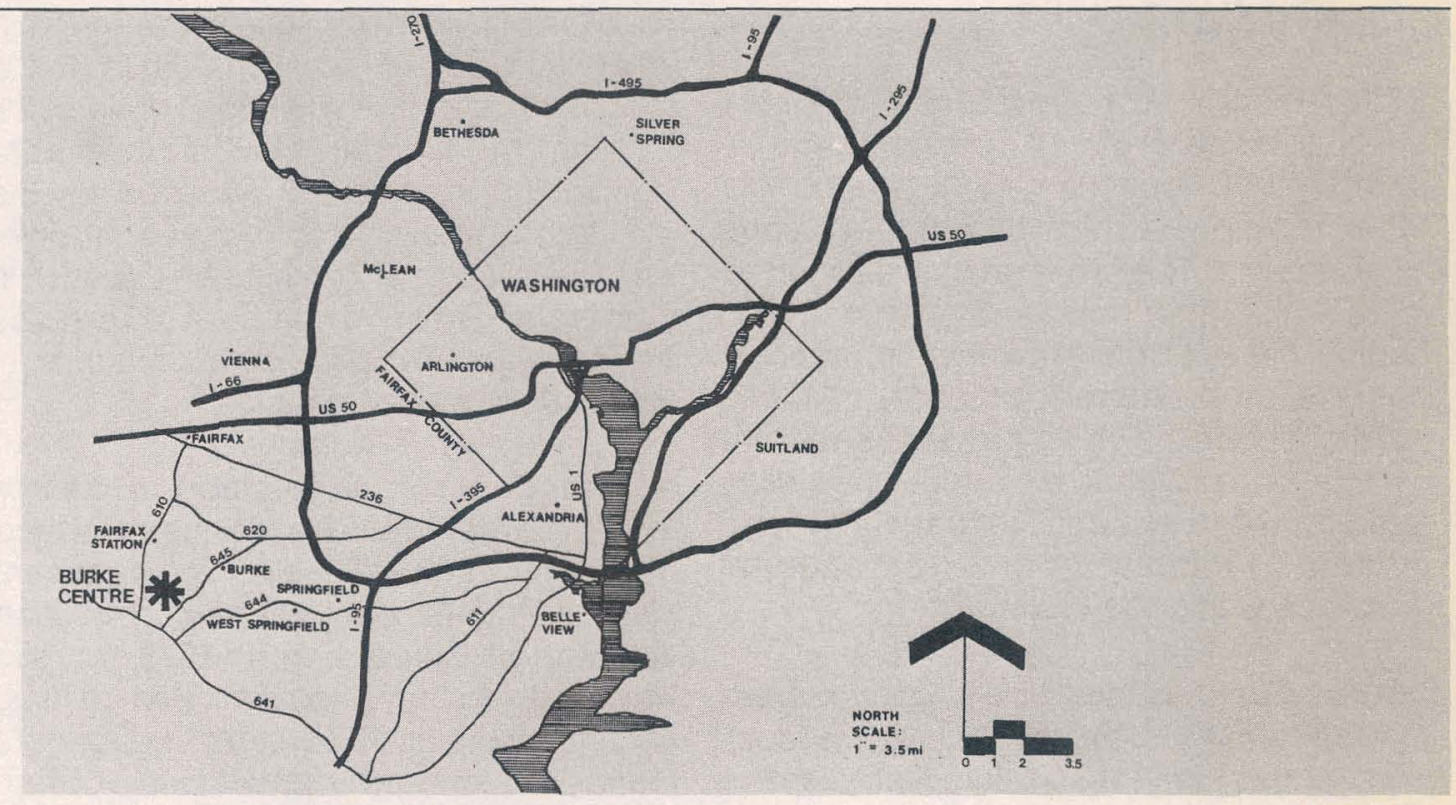

Figure 2. Metropolitan Area

within the Pohick planning area out of a A major regional recreation resource is the County-wide total of 22,200 at the same 854 acre Burke Lake Park located south of stage. The majority of these are also large lot, Burke Centre. The park offers both passingle family units.

In 1970 there were 127,000 households in the County. As of June, 1979, there were 195,600 households in the county showing an increase of over 68,000 homes or more than 8,000 units per year. (Source: Fairfax County PLUS Program and Fairfax County Statistics Department.)

Public schools are located close to Burke Centre. Two combined intermediate school/high school complexes, Robinson and Lake Braddock, are located north of the site with West Springfield High School located further to the east. These schools have been programmed to accept students from Burke Centre. Two existing elementary schools are adjacent to the site: Fairview School on Route 123 and Burke Elementary on Burke Lake Road. Two additional 15 acre elementary school sites are owned by the County. One is located along Burke Centre Parkway and will soon be constructed, following the Reston, Va. Terra-Set Model.

Burke Centre has many other public facilities nearby. Within Fairfax City are the Main Branch of the County Library, the County Government Center, and George Mason University - a major four year university offering a wide variety of undergraduate and graduate degree programs. The Annandale Campus of Northern Virginia Community College is within a ten minute drive with technical and two year degree programs. Library services are also located in the Kings Park Shopping Center on Braddock Road. sive and active recreation including boating (with rental boats available) and an 18 hole, par 3, golf course. Another park. will be located north of Guinea Road as part of a storm water/siltation control dam project. The Fairfax County Plan also calls for the development of a community park to serve Burke Centre.

Fire and rescue services are presently provided by stations in the cities of Fairfax and Burke. A number of transportation improvements, mainly consisting of widening, realigning, and constructing roadways are called for in the county. 


\section{Burke Centre}

The project is a contiguous land assembly, with a number of out-parcels scattered throughout, containing 1218 acres under the single ownership of the Burke Centre Partnership. The entire project is zoned as PRC (Planned Residential Community) under Fairfax County's zoning provisions, and is programmed for 5300 dwelling units. Under the PRC provisions the developer is entitled to a mixture of dwelling and density types and to a variety of commercial, industrial and recreational facilities within the project.

Burke Centre is located adjacent to existing communities, including Lake Braddock and Kings Park West. Burke Centre is the largest consolidated tract in the Pohick Watershed with sewer and water available for development at the present time. The Pohick Planning District is located in the Southwest part of Fairfax County.

Historically, the land was acquired by the Partnership in 1973 from several original owners. The property is located within five miles of the Capital Beltway and less than one hour's drive, during rush hour, to downtown Washington. The land assembly effort was facilitated by the Federal Aviation
Administration which had condemned a large number of small holdings for a proposed airport. When this project fell through, the federally owned lands were put on the market and acquired by the individuals who sold to the present owners, Burke Centre. The intensive growth in Fairfax, beginning in the late '60's made the concept of a planned community at Burke Centre seem feasible.

At the time of acquisition a sewer moratorium existed despite the presence of a sewer trunk at the site. The treatment plant at Potomac was under construction and with its completion in 1975 the site was open to development. Zoning was negotiated during 1975 under the County's planned community provisions. During that process many of the major community development issues were settled. The location of major roads, for instance, was established. So, too, was the basic land use plan showing the location of commercial and industrial sites and proposed high density residential zones. A limit was set on the total number of people in the project as well. All of these decisions remained subject to future adjustment as the development process unfolds, but most have held up to this date.
Development of Burke Centre began in May, 1976 and the first resident moved in during February, 1977. The increasing pressures on Fairfax primarily by the growth of the federal bureaucracy, have generated a rapid pace since opening day. As of the first of April, 1979 there are over 1000 occupied units while another 1000 units have been sold by builders and are under construction. An additional 1500 units have been sold by the Partnership to the builders and another 1700 units are in sales negotiation. The last residential unit should be occupied by 1985 , if not sooner.

The development of the commercial components of Burke Centre will be by members of the Partnership under other business structures. The Village Centre, a convenience shopping facility of 80,000 square feet, is now under construction and will be completed within six months. The Town Center, a larger complex of retail, office and recreational uses, is in the preliminary design phase, and is scheduled to begin construction in 1980. Both centers will have to compete with neighboring commercial projects which proliferate throughout this section of Fairfax County.

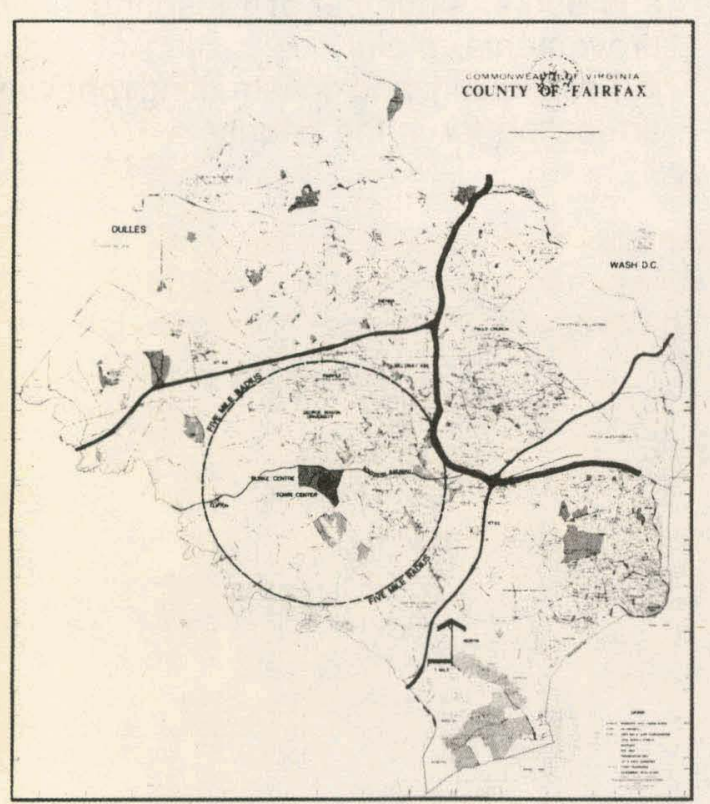

Figure 3. Fairfax County

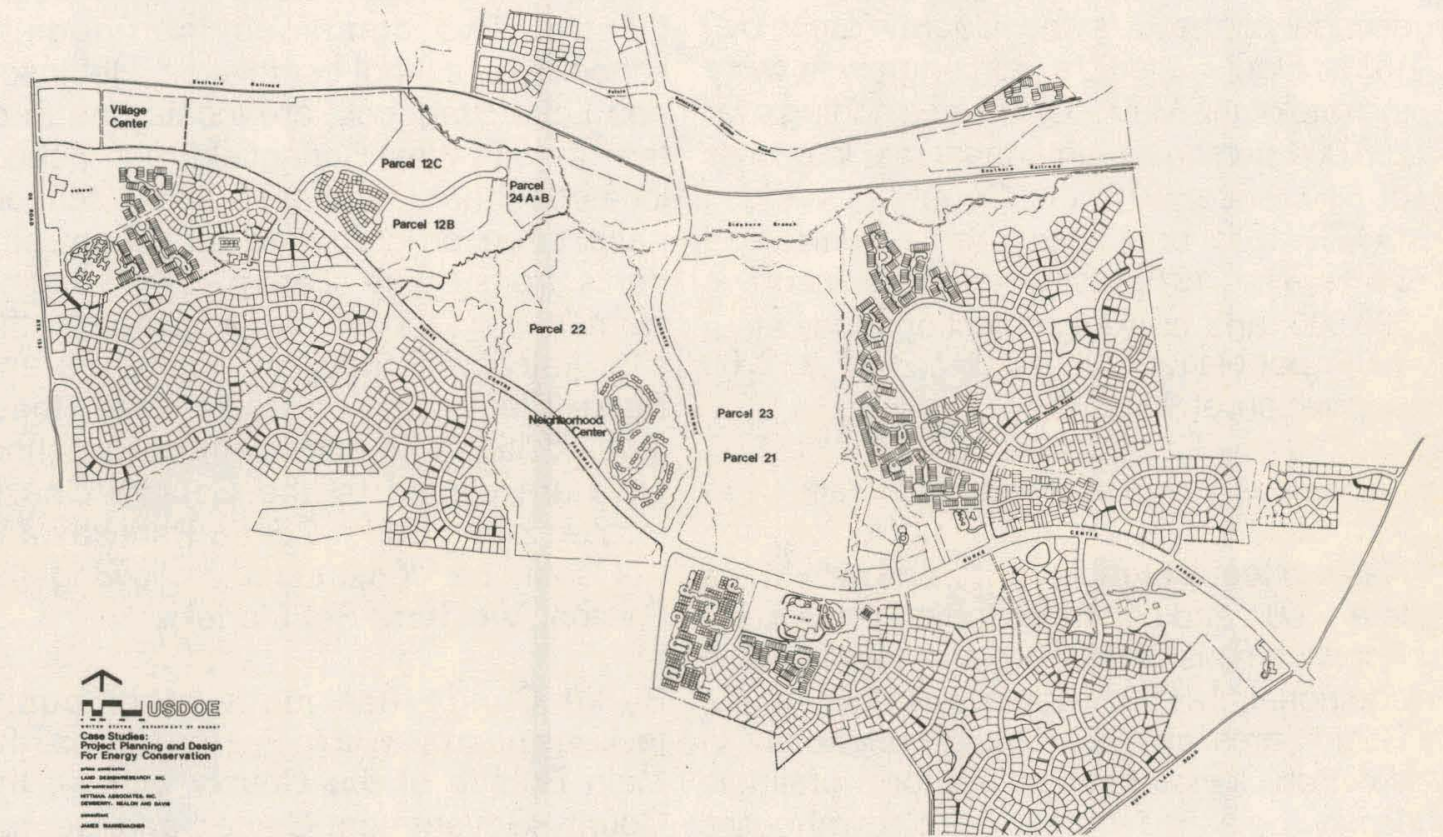

Figure 4. Burke Centre Development Plan 


\section{The Developer}

Burke Centre is the business venture of a partnership comprised of a former home builder who directs development activities, a local attorney who handles the complex relationships with the County and a Washington corporation that has extended the necessary credit to the enterprise. Known as the Burke Centre Partnership, this group is concerned primarily with land development; the creation of value by consolidating and improving raw acreage into a planned and fully serviced community.

Residential construction is done by builders who buy bulk sites from the Partnership. The sites are provided with access to the primary road system of the project and to the main utility lines. The bulk sites, or parcels, are conveyed with zoning intact and with some development restrictions. Conveyance of a parcel from the Partnership to a builder is usually done on a unitcount basis. The units sold are determined by the developer who does schematic site plans to calcuate site capacity.

The Partnership has excellent credibility within Fairfax County. The operating partners have practiced in Fairfax for years and now work there exclusively. Their reputation and knowledge of County policies were key factors in achieving the original Planned Residential Community zoning. Since achieving the overall zoning in 1975 , the developers have successfully negotiated the individual site plans for each bulk parcel and have retained complete control over the project and the development program.

Mr. Milton V. Peterson, who directs development operations for Burke Centre, has reviewed the planning exercise conducted as part of this study. He has contributed both marketing and financial commentary on the Village, Town and Neighborhood Center plans since he is directly involved in their development. The plans for the residential parcels in this study were largely developed before our work began. The energy conserving revisions have been reviewed by the individual builders who purchased them from the Partnership.

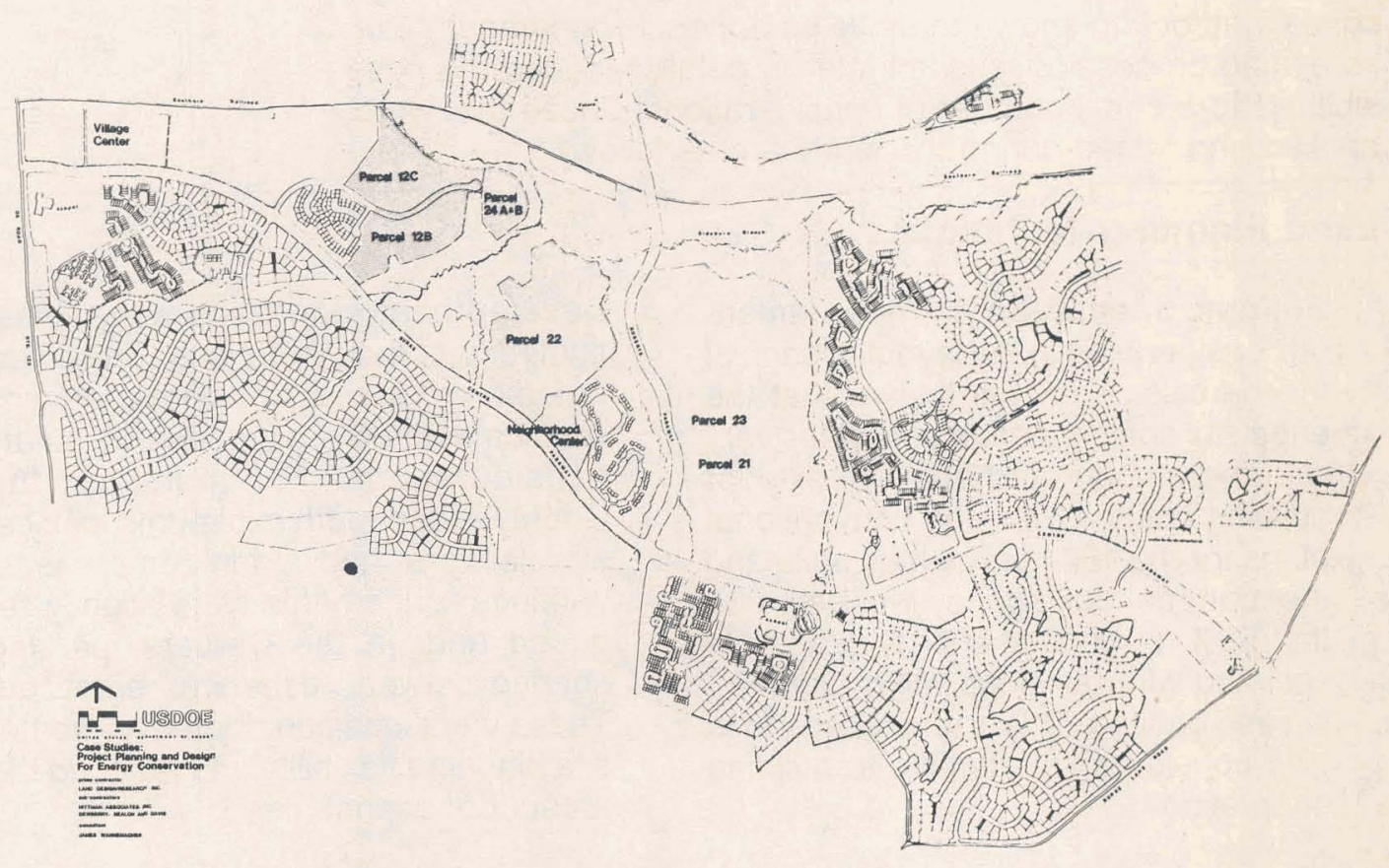

Figure 5. Study Area

\section{The Study}

Burke Centre is a large planned community containing a variety of development parcels. Many of these parcels have been completely developed and built-out. For the purposes of this study we selected parcels that are committed to a program but as yet are undeveloped. With the exception of the Town Center parcel each has been schematically planned to determine its capacity and basic development criteria. The parcels that were studied are:

Parcel 12B This is a linear site of 15.9 acres with frontage on one side along a residential street and backing onto a major open space, adjacent to a new lake. The site is programmed for 100 townhouse units.

Parcel 12C A 24.85 acre land bay roughly square in configuration with road frontage on one side and backing on a wooded stream valley. This parcel has been conveyed to U.S. Homes, a Washington homebuilder, for the construction of 116 four-plex residential units.

Parcel 24A \& B A 7.31 acre site located at the end of a long residential cul-de-sac. This parcel is targeted for 48 low-tomoderate cluster units to be built by The Oxford Development Group.

Parcel 22 A 39.3 acre site bounded by stream valleys on three sides and a parkway on the fourth. This parcel is programmed for 252 garden apartment units and 172 townhouses.

Neighborhood Center A 6.2 acre parcel designated for development as a community recreational facility. The plan calls for a swimming pool, community center, bathhouse, four tennis courts and parking area.

Town Center This 124.4 acre site is located in the middle of the project with access off both of the primary internal collector roads. The program includes retail, office and commercial recreation space together with garden and high rise apartment structures. 
During the course of our study we considered every energy conserving option known to us. (See appendix document.) Our screening process, discussed later in detail, reduced the possibilities to a small number of considerations. Those that were applied and tested during the study are as follows:

\section{Land Planning Techniques}

1. Building orientation was a fundamental consideration in the layout of each of the parcels. It is well known that the effects of solar radiation and winds vary with the amount and angle of exterior building walls. Given the conventional plans for the 1624 residential units and the commercial space, we estimate that $55 \%$ of the total energy usage associated with buildings will go to heating and cooling. This is ample reason to give considerable attention to building orientation.

2. Clustering and consolidation of building space was practiced, particularly in the Centers and elevator residential projects. Proper grouping of structures can take advantage of sun and wind screens created by one structure on another. By consolidating various uses in one building shell the amount of exterior wall area is reduced and greater efficiencies in space conditioning can be achieved.

3. Road patterns were adjusted where possible to shorten trips from access roads to parking lots. Intersections were redesigned or eliminated to reduce the number of stops. Since 17 percent of gasoline usage occurs as a result of interruptions to movement, this aspect is especially important. A side - but usually direct - benefit of shortening on-site streets is the reduction in the length of utility lines, curbs and gutters, sidewalks and, often, drainage systems.

4. Natural screening with earth berms and vegetation contributes to the control of both sun and wind effects on buildings. The rolling terrain and abundant vegetation offered many opportunities to re-site buildings to take advantage of these "free" features or in other cases we created berms by using cut operations.
5. Development standards were investigated in certain instances where variances produced important energy savings with little disruption to safety considerations. For instance, the County's road width minimums for local streets were modified in some cases, parking requirements were slightly reduced and, in the Centers, parking sharing between uses was practiced. These variations contributed to greater site planning flexibility and reduced the amount of asphalt used.

6. Marketing considerations were respected throughout the study. Most of the energy saving plans were carefully studied by the developer and builders to insure no undue liberties were taken with the tastes of the buying public. A number of site plan proposals were, in fact, discarded because of conflict with standards in the home buying or commercial leasing industry. Nevertheless, a few of the plans do contain siting features that may prove difficult to market. These are pointed out at the appropriate place in the report.

\section{Building Systems and Hardware}

1. Water-to-Air heat pumps using ground water can contribute significant savings in the heating and cooling of buildings. Preliminary evidence indicates that the Burke Centre site has adequate ground water at acceptable depths to make wells a reasonable proposition for the savings obtained. This system was employed throughout most of the study area.

2. Water saving devices were tested to attack the 29 percent of building energy use that goes to hot water and 24 percent of total site energy use for producing potable water and treating wastewater. Those devices tested included flow restrictors on water taps and shower heads, low volume flush toilets, mixing valves on showers and water conserving appliances.

\section{Community Planning and Service}

1. A park-and-ride system was tested help reduce the tremendous off-si transportation energy use by Burk Centre. Nearly 60 percent of all enerc will be consumed by the project in mo ing residents to work and major sho ping and moving non-residents on the site to use its services and facilitie

2. A path system for bikes and pede rians was included in the energy ple where reasonably close connectio existed between residential areas ar activity centers. The consolidation buildings in the Town Center made th an especially effective solution to $e$ cessive on-site auto trips.

3. A more efficient solid waste colle tion system was tested. Although $\mathrm{c}$ lection trips consume less than o percent of the project's total ener consumption, major reductions can realized by the use of modern compa tor vehicles.

While this may appear to be a modest li most of the major energy consumption fe tures of a community such as Bur Centre are positively affected by one more of the techniques. More importan every method used in our study can employed today by community develope and builders in most sections of the cou try. They are generally compatible w most local regulations and policies, w utility company operations and are are becoming - acceptable to the Ame can homeowner. 


\section{airfax County Policy}

airfax County is a large, populated, realthy and rapidly growing suburb of Vashington, D.C. The County Governlent, in an effort to keep up with growth ressures, has enacted a variety of olicies designed to manage and direct evelopment, encourage a diversified land se pattern, provide adequate public serices, establish reasonable development tandards and maintain the fiscal integrity $f$ the community. Fairfax policies have ad much to do with the Burke Centre plan nd program and are responsible for many $f$ the development practices in effect on ie Project. The County officials responsile for administrating public policy in Burke ientre were involved in our study from the utset and contributed invaluable assis ance to the formulation of our energy rogram.

County General Plan. The County's Plan encourages the concept of planned development projects, clustering commercial uses and increased reliance on mass transit. As a growth management policy the Plan promotes "..... the use of planned Development Centers as focal points for future growth. As an alternative to sprawl this concept was designed to ..... decrease reliance on the private auto by reducing the length of work trips and making mass transit facilities more easily accessible, ....."

The Plan further promotes orderly development patterns as a means to reduce the cost of public services and to allow for coordinating services with new growth. It recognizes the increasing demand for commercial services in the area around Burke Centre and calls for new commercial centers rather than continued strip development. Another feature of the Plan is its promotion of major employment centers, particularly for office uses, intermingled with residential areas to reduce travel times for the trip to work.

Although the General Plan is only a guide to development in the County, it does clearly define the local commitment to use growth patterns to reduce future energy consumption. In general, the Plan is a supportive document of the policies advocated in this study.
II. Zoning Ordinance. Burke Centre is being developed under the "Planned Residential Community" provisions of the County Zoning Ordinance. These require a minimum of 750 contiguous acres and require an approved comprehensive plan before construction begins. The PRC provides for a balanced community by allowing a variety of housing types, employment areas and commercial services. It encourages a balanced transportation system including mass transit and separate paths for bikes and pedestrians. The PRC also encourages intermixing uses and taking advantage of the natural environment in site planning. In the early years of development under the PRC provisions, the Burke Centre Partnership obtained approval for reduced road widths in residential areas and for variances to side yard requirements. It has proven to be a very flexible development process.

III. Public Facilities Program. Many of the public facilities required to serve the Burke Centre area have already been committeed to a specific location. Although we urged the consideration of the Town Center as a potential commercial-community complex, the County is not in a position to designate many new facilities at this time.

One possibility is a new library which presently is considered for a site south of Burke Centre. It is the County's policy to site libraries near commercial centers, as in Reston, and further study will be given to the Town Center as a library location. The County does have a General Services Department that leases space for public facilities. The possibility of placing various County services such as a library, community center, elderly center, etc., in leased space in the Town Center should be considered.
IV. Economic Development. The County has lagged in building an employment base comparable to its residential growth. Recently the Fairfax Economic Development Authority has expanded its program to attract new business and industry. The Director of the Authority was approached during our study to determine his views on marketing the Town Center area for office and other compatible business uses. We stressed the desirability of combining business and commercial space in a compact center immediately adjacent to a variety of housing types. The direction expressed a positive attitude towards promoting the Town Center even though road access to Burke Centre is still in need of upgrading. We feel the County's promotion of multi-use centers is a major step in reducing overal transportation needs and the cooperation of agencies such as the Economic Development Authority is essential to carry out that policy.

V. Parking. In our energy plan for the Town Center we showed a reduction in total parking below the minimum required by the County. Our rationale was based on the sharing of parking by the individual uses that have differing peak demand times. By reducing the total parking for the Center, the remaining land will accommodate a park-and-ride lot. Although the County regulations do not acknowledge sharing as a valid argument for reducing aggregate parking requirements, the officials reviewing our plan indicated a willingness to consider seriously our proposal.

VI. Energy Policy. A commission was appointed by the County in 1978 to study measures related to energy conservation that could be implemented by local government. The commission completed its work and submitted a lengthly list of actions for consideration. Many of the site and community planning recommendations made in our study were mentioned in the commission's report. We have encouraged positive action by the County on the recommendations. 


\section{Electric Service}

Burke Centre is provided with electric service by the Virginia Electric Power Company (VEPCO). At the time of our study VEPCO had installed the main service trunks throughout the Project and was serving the community with power. Gas service is not available to new users in this section of Virginia and none is provided at this time to Burke Centre.

Discussions were held at the outset of our study with VEPCO officials concerning energy conservation programs and VEPCO policies. They expressed a desire to work with us as needed during the study process and to provide available data for our research. They also discussed their willingness to undertake more direct participation such as metering model energy homes.

Because we declined to pursue such issues as on-site energy generation, the need to involve VEPCO directly in our program was diminished. None of the recommendations made in this report require specific action or approvals by the utility company.

\section{Marketing Considerations}

Fairfax County has become the principal housing market in the Washington metropolitan area. Its strong appeal to the middle echelon federal employee has given Fairfax one of the highest per capita income figures in the region.

Burke Centre's developers are well acquainted with the marketing conditions in the County. They have carefully directed the project to appeal to the educated professional with a family income of $\$ 25,000$ to $\$ 40,000$. Although the builders in Burke Centre offer a fairly wide choice of housing styles and types, the price range is strongly focused in the $\$ 60,000$ to $\$ 80,000$ range. Some effort has been made to broaden the market base by promoting several townhouse and garden projects at a more modest cost.

Burke Centre has established itself as a successful housing venture in the competitive Washington market by featuring reputable local and national homebuilders operating in the context of a planned community environment. While the latter has been heavily promoted it has been cautiously handled by the developer. The extraordinary front end costs for community facilities that burdened Reston have been avoided in Burke Centre. Nevertheless, the Project does offer a variety of outdoor recreation facilities, a major open space and path system. The land plan is clearly sensitive to community structure and natural features such as stream valleys.

The area immediately around the Project has been extensively zoned for commercial use. Much of it has already been developed into strip convenience centers, free standing retail and eating establishments and office space for personal and professional service businesses. A number of major shopping malls are in operation within a 20 minute drive of the Project, and, of course, downtown Washington is less than an hour's drive away. In some respects Fairfax has been over developed with commercial uses in anticipation of continued population growth through the 1980's. The developers of Burke Centre have been careful with the planning of their Village and Town Center commercial space, knowing that these facilities must be highly competitive to survive.
We will make repeated references throughout this Report to various marketing considerations that caused us to abandon or modify our recommendations. It is certainly no secret that a strong attachment to today's energy intensive lifestyles presents major obstacles to reducing energy consumption throughout the country. Since our purpose is to test those factors affecting consumption that could be employed now, we were very concerned with market acceptability. Any recommendation requiring a substantial departure from current standards was discarded at the outset. Perhaps several case examples will further clarify our approach to market issues.

We limited our experimentation with residential buildings to giving them the best possible site orientation with maximum slope and vegetation protection. We did not consider major changes to housing styles, building materials and basic design features. As a result, the builders expressed almost no concern regarding the marketability of our ideas.

When considering community services such as trash collection we discarded the notion of central pick-up points requiring residents to haul their refuse a certain distance. We did explore the use of better compactor trucks to reduce the number of trips each truck must make.

In our review of available technology, we ruled out any serious study of on-site power generators partially because of the potential adverse impact on the Project's environment. We did, however, pursue the notion of using water-to-air heat pumps since the tapping of ground water was not considered as a negative marketing activity.

We believe our concern with marketing issues is one of the real strengths of the study. Each recommendation that was tested had either been proven to have market acceptability or was thoroughly reviewed by the developer before we proceeded. 


\section{Town Center}

Site Conditions The town center site of approximately 124 acres is located in the geographical middle of the Burke Centre development. It is bounded on the south by the major collector for the community, Burke Centre Parkway; and on the west by the proposed Roberts Parkway.

Its physical characteristics are typical of all of the parcels chosen for this study. The land slopes generally from south to north, with a vertical drop of $140^{\prime}$ from the highpoint along Burke Centre Parkway to the Sideburn Branch on the north.

Minor drainage courses and small streams further subdivide the parcel flowing to the northeast and northwest from a centrally located ridgeline.

Several opportunity sites are evident for ponding.

A very small portion of the site is level with the majority of the slopes in the $5-15 \%$ range. Approximately $7 \%$ of the slopes are over $20 \%$.

\section{Land Use Program:}

The site is to be developed for a variety of commercial uses and a mixture of high and medium density rental housing units. Although a specific marketing program has not been set, the developers intentions are to construct $100,500 \mathrm{sq}$. ft. of retail space, 200,000 sq. $\mathrm{ft}$. of general lease office space and a number of recreational uses to be operated on a commercial basis. The retail leasing plan is still undetermined but the general approach is to get an anchor tenant of 40,000 to $50,000 \mathrm{sq}$. $\mathrm{ft}$. and fill the remainder of the space with small shops and eating establishments. The recreation program is also in the early preliminary programming phase with consideration being given to a cinema, a dinner theatre, a bowling facility, a raquetball/health club and perhaps, a roller rink. The office program will be developed in stages as market demand is generated. There will likely be two-to-four separate office structures at completion of development. The residential program envisions 336 units in two or three elevator structures and 600 units in garden-type buildings. Parking requirements are 2189 spaces for the commercial uses and 1446 spaces for the residential units.

\section{Business Plan:}

The operating partners of Burke Centre Partnership intend to acquire the land for the commercial uses under a separate business arrangement and develop most or all of the program for their own account. They have retained a marketing/design consultant to begin schematic planning for this portion of the Town Center. No firm disposition plan exists for the residential section of the site. Market conditions do not support elevator housing at this time so development in the residential sites will likely be somewhat delayed.

\section{Base Development Plan:}

At the time we commenced our study no site planning had been done on any portion of the Town Center. We therefore produced a plan employing typical siting standards for suburban commercial centers. The retail space was arranged in an L-shaped strip configuration with the cinema located at one end and the major tenant at the other. The required 1,043 parking spaces were put into a large, single lot facing the shops with access off a service drive from the Parkway. Additional parking for the cinema was sited behind the facility to avoid conflict with retail patrons.

The office space was distributed in three buildings each with its own parking lot. The buildings were grouped to provide the opportunity for a common exterior plaza or other amenity. The dinner theatre site was placed on the Parkway for visibility purposes and to share some of the office parking. Each of the major recreation facilities were sited in a separate building but in the same general area, with the remaining apartments located in a conventional manner.

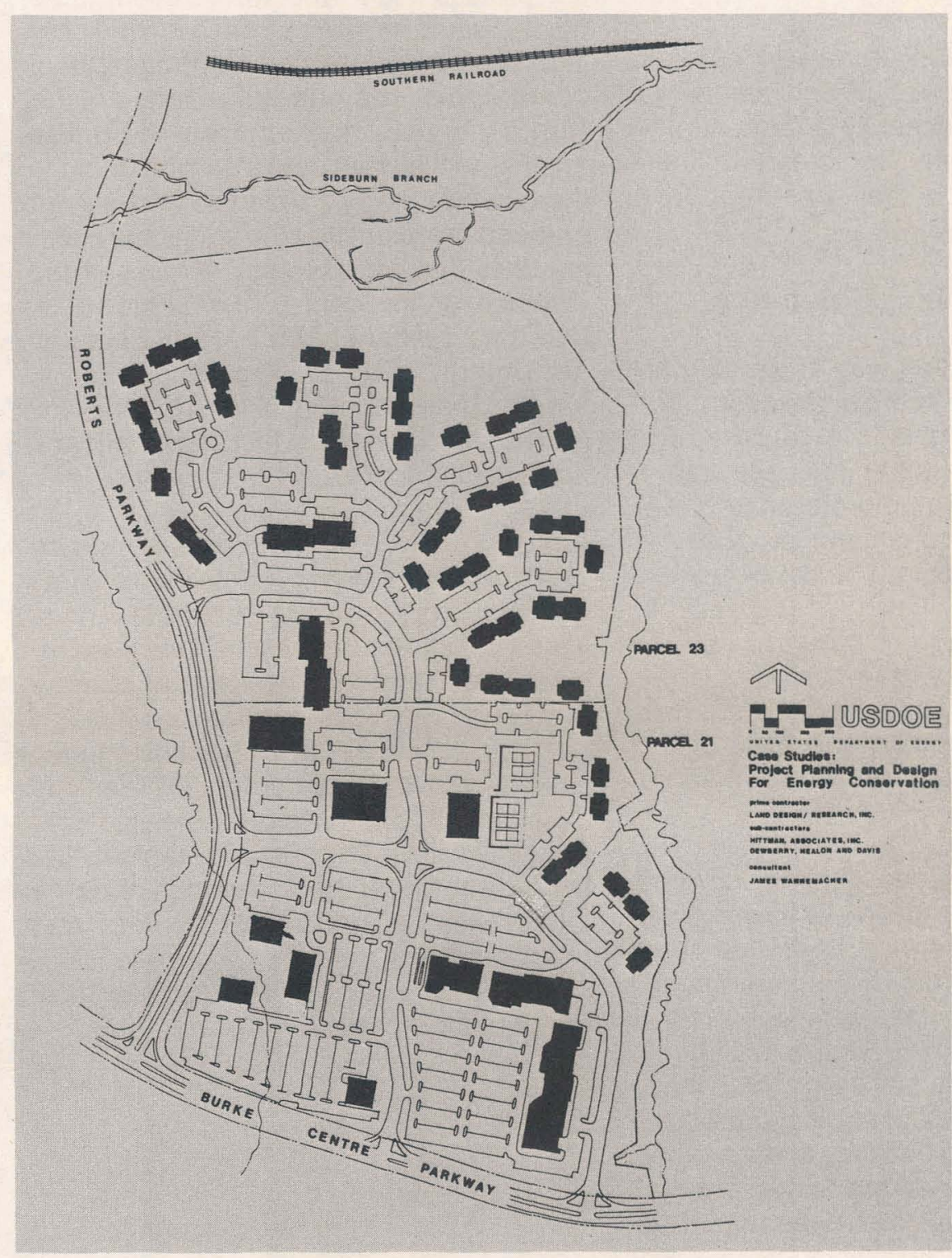

Figure 6. Base Plan • Town Center 


\section{Energy Considerations:}

The base plan presented few opportunities for walking from one activity to another. For instance, the offices are remote enough from the retail center that walking to lunch is reasonable only on nice days. No more than 10 percent of the residential units are within walking distance of the retail and office space.

The configuration and siting of the buildings create substantial exposure to summer heat gain and only modest opportunities for solar gain in winter. The creation of a large number of single-use, individual buildings produces excessive exterior wall space which increases heating and cooling costs.

The separation of uses requires that each building have its full share of parking spaces, despite the fact that periods of peak use vary considerably between them. The large areas of service roads and lots forces the full utilization of the 125 acres. As a result, substantial earthwork is required to level out the terrain and subsequently most of the existing vegetation must be removed.

The internal road system provides direct access to each building and works well with the site. Of necessity, a large number of stops and yields are created. These conditions add to the consumption of gasoline.

\section{Energy Conserving Solutions:}

Building consolidation was explored, particularly for the commercial space. Coincidental to our attempts to reconfigure the office, retail and recreation uses into a compact cluster of buildings, the developer's design consultant produced a similar schematic plan. The developer expressed a strong opinion in favor of the marketing advantages inherent in this approach. He believes the resulting larger buildings and massing effect will improve the center's visual impact on the public and produce greater comfort and convenience for the consumer.

Our approach to consolidation included putting the office space in two larger structures and siting them on the same court serving the retail space. The bowling, racquetball, and roller rink were consolidated into one large building with a multi-level format and similarly placed on the central court. As a result, all commercial space is within easy walking distance of each other. This allowed the parking to be massed around the commercial uses on three sides, giving more flexibility to its use. Initially, no spaces were removed since
County regulations do not recognize parking sharing at this time. County planning officials did indicate a willingness to consider the possibility of allowing sharing in circumstances such as this in the future. However a percentage of the required spaces were designated for a park and ride lot.

During the early phase of our study an attempt was made to site the commercial complex in a central location in the 125 acre Town Center. A site on the eastern stream valley and midway between Burke Centre Parkway and the northern boundary was selected for testing. This location offered a natural "bowl" to place the buildings within, thus reducing excavation work and providing natural screening from winds. It also allowed for the placement of the high density housing around the complex, giving a larger number of the units a walk-to relationship.

This suggestion was considered unworkable by the developer. The retail and office space was too far from the main road to make it marketable. He believed that not only the prospective merchants, but also the professionals who would occupy the offices would shy away from a low visibility location. The extensive development of competitive commercial space in the Burke Centre market area mitigated against, in the developer's opinion, moving the complex away from the Parkway. He further pointed out that the additional housing units that were brought within walking distance of the center represented less than one percent of its potential market. The energy savings of placing a large, sub-regional commercial center near several hundred units is, in fact, too small to be a site location criteria.

An opportunity to promote a park-and-ride service was presented when the buildings were clustered and consolidated. Just over 100,000 square feet of land was removed from parking coverage by a variety of paving reduction techniques, including compact car spaces and shortening those spaces on the perimeter of the lots utilizing curb overhangs. The service road system was also reduced substantially (22 percent) through the consolidation of the parking areas. The $211,000 \mathrm{sq}$. ft. of land removed from paving coverage was replanned as a 277 space lot for local commuters.
These spaces were sited at the far end of the main parking lot from the commercial buildings and would be available for overflow, evening and weekend shopping needs. Since public bus service is already planned for the Burke Centre Parkway, the provision of a park-and-ride lot immediately adjacent to it should work well in future regional transit programs. Nearly all of the Town Center structures, commercial and residential, were oriented for southern exposure. As a result, the amount of wall surface exposed to winter sun was increased by twenty-four percent. Conversely, the wall exposure to summer heat gain came down by fifty percent. The resulting increase of wall area facing winter winds was minimized by the retention of an additional 9 acreas of natural vegetation in strategic locations north and west of many of the buildings. Further, the savings realized in various site development costs (discussed later in this section) allowed us to expand the budget for shade and evergreen trees by $\$ 84,000$, or 46 percent.

By arranging the parking on three sides of the commercial center, a fourth edge was available for siting some of the residential units. We chose to site both of the high rise structures in this area giving these 336 units a comfortable walking distance to the center. The developer was in favor of this scheme because he felt both the commercial leasing and apartment leasing programs would benefit. This type of convenience is especially important to the high rise apartment market which generally includes singles and couples seeking urban conveniences.

The road network was redesigned to reduce the number of interference points in traffic flows.

A path system for bicycles and pedestrians was provided to connect most of the Town Center garden units to the commercial center. Where appropriate, the paths were aligned to connect to the community system.

All of the commercial buildings, totaling 400,000 sq. ft. have been sunk a half level below grade to reduce the surface wall exposure.

Finally, each of the buildings in the Town Center has been provided with a waterto-air heat pump system. Initial inquiries have indicated the presence of adequate ground water to support the combined systems. There are no County or other regulatory restrictions that would prohibit the use of ground water for this purpose. 


\section{Energy Savings Potential:}

Table 1 shows the total energy consumption for the commercial space in the Town Center assuming the Base Plan is used. Table 2 indicates the usage for the same space provided the energy conserving features are employed. The difference in annual energy consumption is about $7,000 x$ $10^{6}$ BTU or a savings of 27 percent. The savings in costs for energy are over $\$ 50,000$ annually from using the energy conserving plan. Hot water savings account for $\$ 26,100$ of this reduction. The remainder comes from the reduction of heating and cooling costs through the use of the water-to-air heat pumps, the proper orientation of buildings, the sinking of the lower levels and the reduction of total wall surface.
There are several areas of transportation savings associated with the commercial center energy plan. First, the reduction of friction points (stops and lights) in the service road system results in a daily savings of $\mathbf{4 3}$ gallons of gasoline or 25 percent of the gas consumed at stops and lights in the base plan. Second, the path system connecting the Center to the adjacent housing areas should shift some trips from the car to walking or biking. Table 3 gives the savings realized for various percentages of walking/biking trips. We presume that if up to 20 percent of the trips were shifted to walking that the savings would amount to 5 gallons of gasoline per day or 1500 gallons per year. Third, by compacting the Center it can be assumed that certain trips to it will have at least two destinations. Further, no trips will be involved in moving from one use in the Center to another since all buildings are closely related to each other. These features should produce a savings in gasoline usage on-site and off-site of 26 percent or about 40 gallons per day. Taking all of the transportation savings into account, the total annual savings of gasoline for the same level of usage will be an estimated 26,400 gallons. The cost savings realized will of course vary with the cost of a gallon of gasoline. It is probably safe to assume that a minimum of $\$ 23,000$ in savings is involved from 1979 forward.

Table 1. Base Plan Total Energy Per Commercial/Recreational Type $\times 10^{6} \mathrm{BTU} / \mathrm{Yr}^{1}$

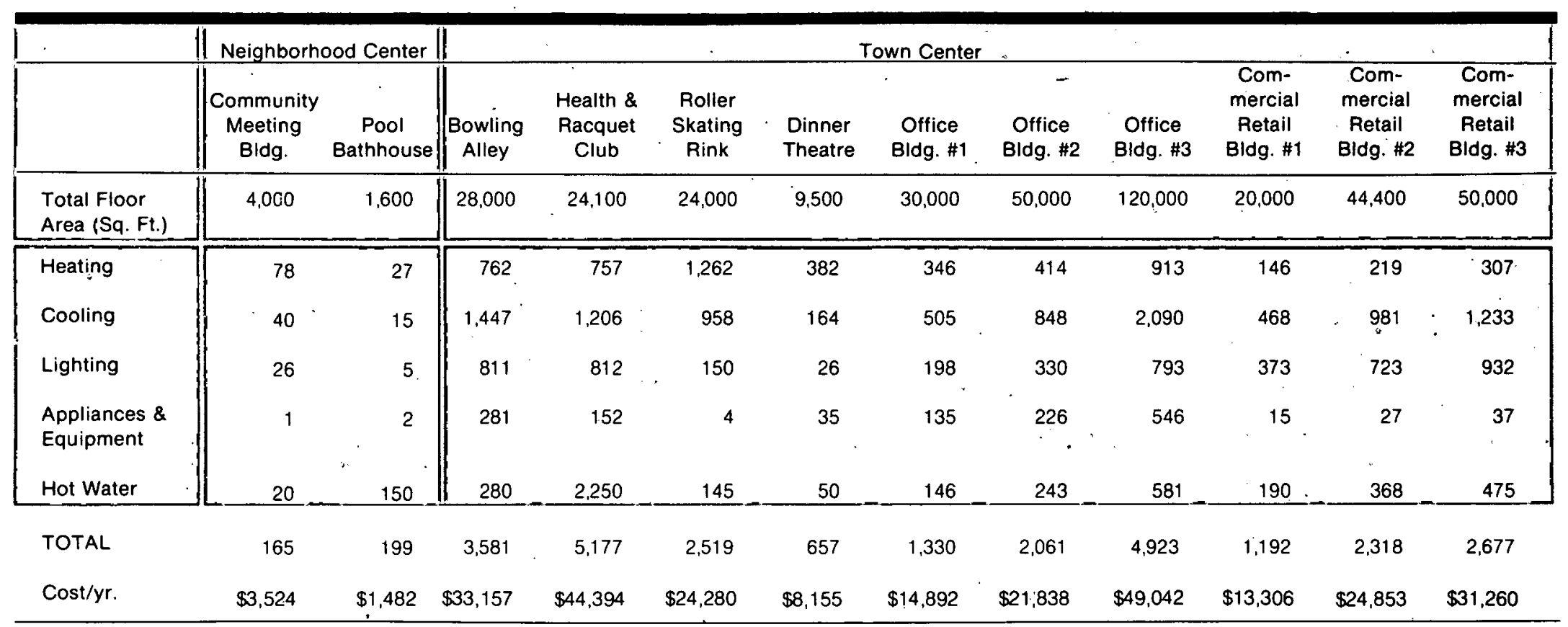

' All have air-to-air heat pumps except Office \#1, 2, 3 which have electric resistance heat

Heat Pump C.O.P.: Heating 1.8 Cooling 1.7

Distribution Efficiency: 0.95

Electric Resistance: $\quad 0.95$ 
Table 2. E/C Plan Total Energy Per Commercial/ Recreational Type $\times 10^{6} \mathrm{BTU} / \mathrm{Yr}$

\begin{tabular}{|c|c|c|c|c|c|c|c|c|c|}
\hline . & $\begin{array}{l}\text { Neighborhood } \\
\text { Center }\end{array}$ & \multicolumn{8}{|c|}{ Town Center } \\
\hline & $\begin{array}{l}\text { Community } \\
\text { Meeting \& Pool } \\
\text { Bathhouse } \\
\text { Bldg }\end{array}$ & Retail & $\begin{array}{l}\text { Retail/ } \\
\text { Office }\end{array}$ & Retail & $\begin{array}{l}\text { Retail/ } \\
\text { Office }\end{array}$ & $\begin{array}{l}\text { Movie } \\
\text { Theatre }\end{array}$ & $\begin{array}{l}\text { Office/ } \\
\text { Retail/ } \\
\text { Dinner } \\
\text { Theatre }\end{array}$ & Recreational & Mall \\
\hline $\begin{array}{l}\text { Total Flr. Area } \\
\text { (Sq. Ft.) } \times 10^{3}\end{array}$ & 5,600 & 45,300 & 103,500 & 20,200 & 75,900 & $.9,500$ & 69,500 & 76,100 & 53,200 \\
\hline Heating & 12 & 21 & 320 & 23 & 250 & 275 & 432 & 532 & 521 \\
\hline Cooling & 34 & .826 & 1,103 & 321 & 767 & 114 & 790 & 1,255 & 1,804 \\
\hline Lighting & 31 & 803 & 816 & 358 & 678 & 75 & 645 & 1,773 & 1,586 \\
\hline $\begin{array}{l}\text { Appliances \& } \\
\text { Equipment }\end{array}$ & 3 & 31 & 14 & 283 & 39 & 230 & 437 & 19 & \\
\hline Hot Water & 40 & 150 & 377 & 67 & 272 & 32 & 222 & 675 & 0 \\
\hline Well Pumps & 1 & 1 & 6 & 1 & 1 & 1 & 2 & 1 & 2 \\
\hline TOTAL & $i 21$ & 1,832 & 3,046 & 784 & 2,251 & 536 & 2,321 & 4,673 & 3,932 \\
\hline Energy Cost & $\$ 3,292$ & $\$ 20,075$ & $\$ 35,067$ & $\$ 9,887$ & $\$ 25,097$ & $\$ 7,083$ & $\$ 27,764$ & $\$ 44,728$ & $\$ 40,788$ \\
\hline
\end{tabular}

\footnotetext{
' All have water-to-air heat pumps

Heat pump C.O.P.: Heating 4.0$$
\text { Cooling } 3.0
$$

Distribution efficiency: ${ }^{\circ} 0.95$
}

\begin{tabular}{|c|c|c|}
\hline $\begin{array}{l}\text { Percent of } \\
\text { Internal } \\
\text { Trips. } \\
\text { Shifted } \\
\end{array}$ & $\begin{array}{l}\text { Total Fuel } \\
\text { Savings } \\
\text { (Gal/Day) }\end{array}$ & $\begin{array}{c}\text { Tòtal Energy } \\
\text { Savings } \\
\text { (Btu/yr.) }\end{array}$ \\
\hline $10 \%$ & 2.4 & $111 \times 10^{5}$ \\
\hline $20 \%$ & 4.9 & $222 \times 10^{6}$ \\
\hline$\therefore 30 \%$ & 7.3 & $333 \times 10^{6}$ \\
\hline $40 \%$ & 9.7 & $444 \times 10^{6}$ \\
\hline $50 \%$ & 12.2 & $556 \times 10^{6}$ \\
\hline $60 \%$ & 14.6 & $667 \times 10^{6}$ \\
\hline $70 \%$ & 17.1 & $778 \times 10^{6}$ \\
\hline $80 \%$ & 10.5 & $889 \times 10^{6}$ \\
\hline $90 \%$ & 21.9 & $1,001 \times 10^{6}$ \\
\hline $100 \%$ & 24.4 & $1,112 \times 10^{6}$ \\
\hline
\end{tabular}

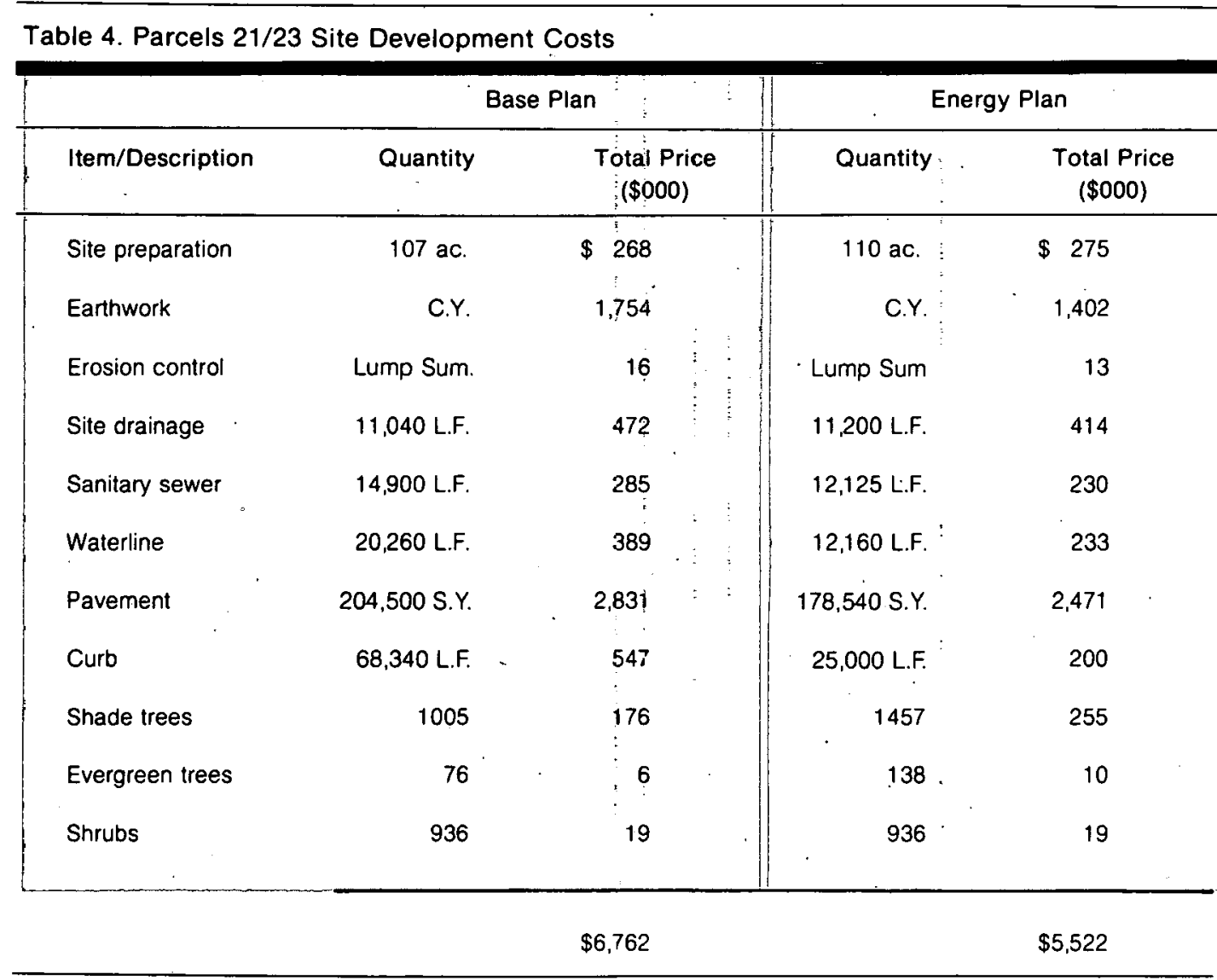

$\begin{array}{lr}\text { Energy Plan Savings }(\$ 000) & \$ 1,240 \\ \text { Greatest Savings: } & (\$ 000) \\ \text { Earthwork } & \$ 352 \\ \text { Water } & 156 \\ \text { Pavement } & 361 \\ \text { Curb } & 347\end{array}$




\section{Cost of Energy Conservation:}

Table 4 summarizes the development costs for land improvements for both the base plan and the energy plan. The Appendix Document provides detailed cost take-offs for the two plans. The bottom line for site development costs is an overall reduction of $\$ 1.2$ million, or just under 20 percent when the energy plan is used. As for many of the other parcels in Burke Centre, the largest part of these reductions stem from reduced earth moving and lesser amounts of paving and utility construction. In the Town Center these were made possible by clustering the commercial complex to the extent that the elevator apartment units could be included within the original land bay that held only the commercial space. This added flexibility to the garden apartment site plans, and provided for greater retention of natural features. It should be noted that reduced site development estimate for the energy plan includes the addition of $\$ 85,000$ for new tree plantings to help screen the buildings.

Tables 5, 6 and 7 depict the costs for the space conditioning equipment in the two plans. The overall added costs for the wells, pumps and piping to serve the Town Center are $\$ 122,000$ for the high rise units ( $\$ 363$ per unit); $\$ 348,000$ for the garden units ( $\$ 580$ per unit); and $\$ 124,000$ for the commercial space ( $\$ .40$ per square foot).

The residential program for the Town Center is significantly impacted by the energy measures as well. The high rise units will consume $20 \times 10^{6}$ BTU's/unit/ year less as a result of the use of the water-to-air pumps, the water conserving equipment and by virtue of the proper site orientation. That amounts to a cost savings of $\$ 220$ per year for each of 336 units. Put another way, the monthly impact per unit is a net savings of over $\$ 18$. There is a similar savings in the garden apartment units.

‘See Table 19 from appendix, E/C Plan Energy Use per average residential unit.
Table 5. Base Plan Space Conditioning Equipment Costs

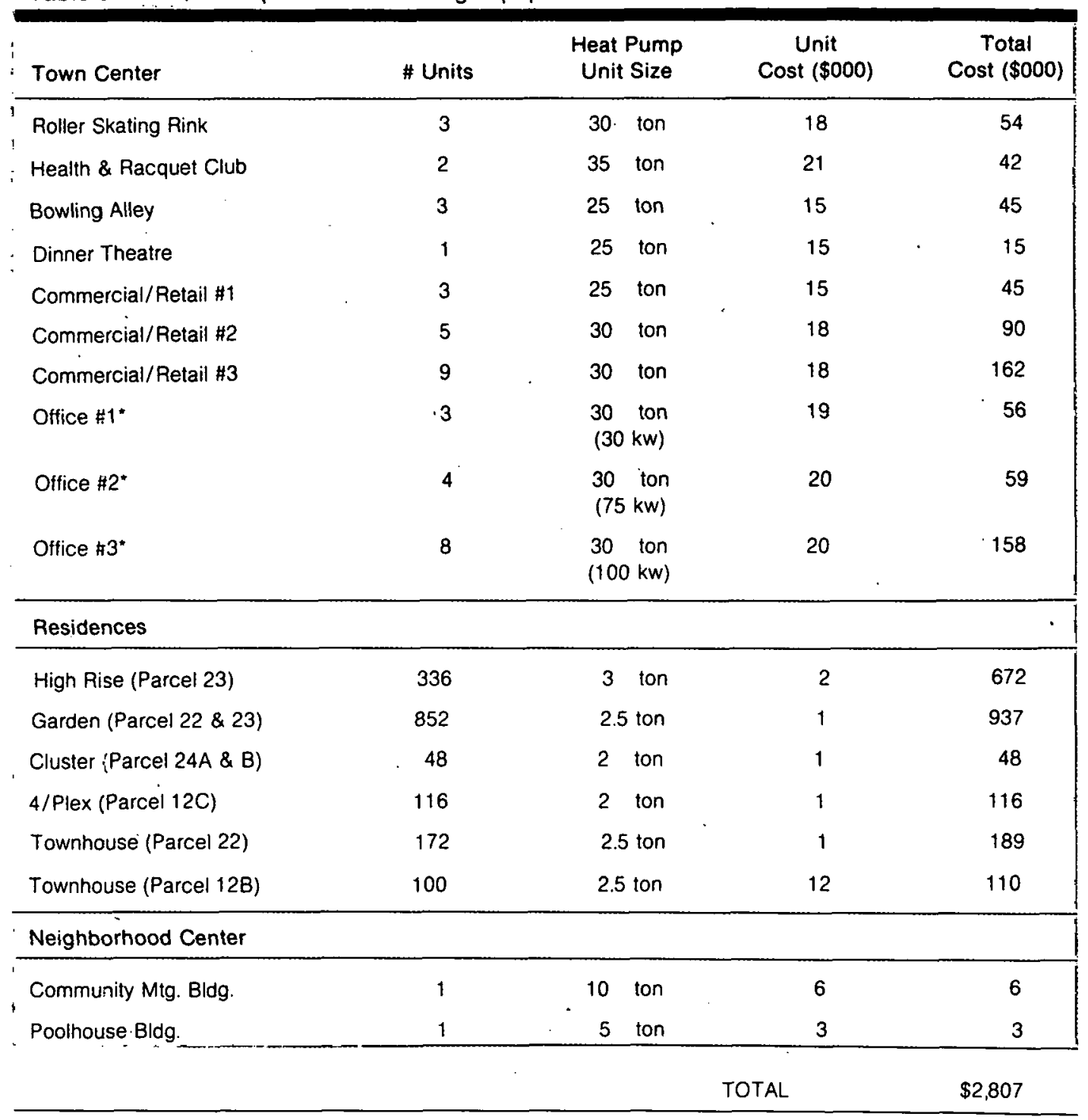

*Contain electric resistance forced air heat and unitary A/C units.

Table 6. E/C Plan Space Conditioning Equipment Costs

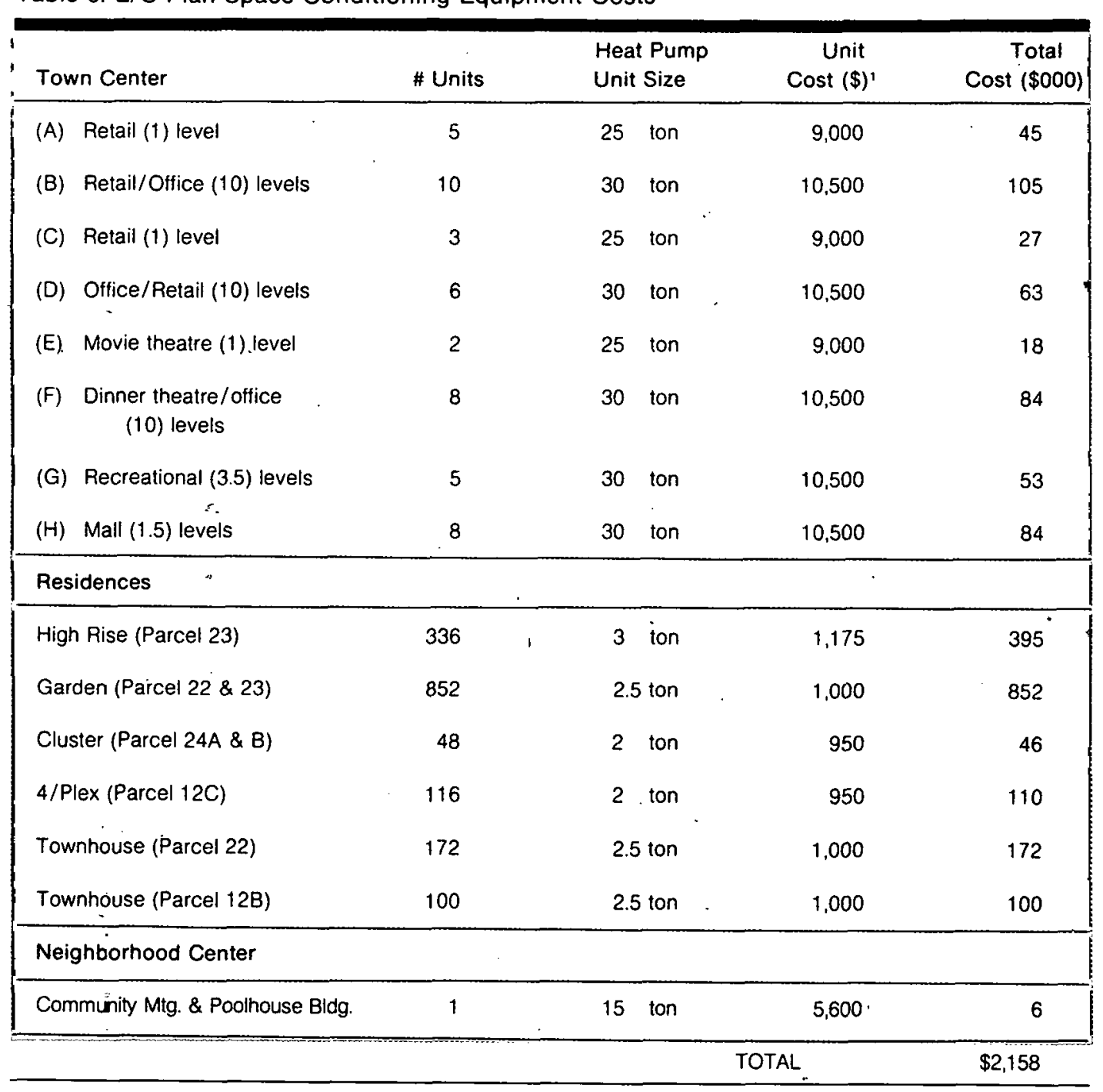

'Excludes piping, pump and well costs 
Tatle 7. E/C Plan Associated Well and Piping Costs

\begin{tabular}{|c|c|c|c|c|c|c|}
\hline . & $\begin{array}{l}\text { Total GPM } \\
\text { Required }\end{array}$ & $\begin{array}{l}\text { Total Piping } \\
\text { Lineal Feet }\end{array}$ & $\begin{array}{c}\text { Head Loss } \\
H(f t)^{\circ}\end{array}$ & $\begin{array}{l}\text { Pump } \\
\text { Energy Use } \\
\text { (kwh/yr) }\end{array}$ & $\begin{array}{l}\text { Total Well } \\
\text { Cost }\left(10^{3} \$\right)\end{array}$ & $\begin{array}{l}\text { Total Piping } \\
\text { Cost }\left(10^{3} \$\right)\end{array}$ \\
\hline \multicolumn{7}{|l|}{ Town Center } \\
\hline (A) Retail (1) level & 300 & 640 & 1.8 & 127 & 26.6 & 8.7 \\
\hline (B) Retail (10) levels. & 720 & 1,280 & 10.8 & 1,688 & 63.7 & 17.4 \\
\hline (C) Retail (1) level & 180 & 384 & 6 & 25 & 15.9 & 5.2 \\
\hline (D) Office/Retail (10) levels & 432 & 768 & 3.1 & 314 & 38.9 & 10.4 \\
\hline (E) Movie theatre (1) level & 120 & 256 & .3 & 8 & 10.6 & 3.5 \\
\hline $\begin{array}{c}\text { Dinner lheatre/Otfice } \\
\text { (10) levels }\end{array}$ & 576 & 1,024 & 4.5 & 608 & 51.3 & 13.9 \\
\hline (G) Recreational (3.5) leveis & 360 & 640 & 2.5 & 211 & 31.9 & 8.7 \\
\hline (H) Mall (1.5) levels & $576^{-}$ & 1,024 & 4.5 & 608 & 51.3 & 13.9 \\
\hline \multicolumn{7}{|l|}{ Residences } \\
\hline High Rise (Parcel 23) & 2,688 & 1,190 & 67.2 & 42,358 & 237.0 & 16.2 \\
\hline Garcen (Parcel 22) & 1,512 & 3,530 & 252. & 89,349 & 135.0 & 48.0 \\
\hline Garčen (Parcel 23) & 3,600 & 6,600 & $1,080.0$ & 911,724 & 319.0 。 & 89.8 \\
\hline Clusser (Parcel 24A \& B) & 240 & 2,020 & 28.8 & 1.621 & 21.2 & 3.3 \\
\hline 4/Plex (Parcel 12C) & 580 & 4,990 & 174. & 23,665 & 51.3 & 7.9 \\
\hline Townhouse (Parcel 22) & 1,032 & 2,410 & 96.3 & 23,305 & 92.0 & 14.0 \\
\hline Townhouse (Parcel 12B) & 600 & 5,000 & 160. & 22,512 & 53.1 & 8.2 \\
\hline Neighborhood Center & & & & & & - \\
\hline $\begin{array}{c}\text { Community Mtg. \& Pool } \\
\text { Bathhouse Bldg. }\end{array}$ & 36 & 800 & 1.4 & 12 & 3.5 & .5 \\
\hline & & & & TOTAL & $\$ 1,202,000$ & $\$ 269,600$ \\
\hline
\end{tabular}

\footnotetext{
Based on cooling requirement $10^{\circ} \mathrm{F}$ T across condenser

2 hiead loss from well heads to water connection hookups.

${ }^{3}$ Assumes $80 \%$ efficiency of pump and water operating al an average of 1000 hrs. per year

- Assumes at least $200 \mathrm{GPM} /$ well, 400' well at $\$ 10,000,200$ GPM submersible pump at $\$ 7700$

5 Eased on $\$ 13.60$ per LF
}

\section{Suramary of Town Center:}

The energy conserving plan that is shown and was tested for the Town Center is, for several reasons, superior to the base plan shown.

1. The marketability of both the commercial space and the high rise units has been enhanced in the developer's opinion, by the clustering approach, and by the siting of the high rise units near the commercial space.

2. The development of a park and ride lot at the commercial center should save 45,000 gallons of gasoline annually for the local commuters.

3. The combined savings in site development costs exceed $\$ 1.2$ million dollars. As we've pointed out elsewhere, these savings are as much the result of good site planning as of energy-related issues. Nevertheless, the two are interrelated.

\section{Parcel 22}

\section{Site Conditions}

This site exhibits many of the same qualities as the town center. It's 39.3 acres is bounded on the south by the Burke Center Parkway and on the north by the Sideburn Branch Stream valley. It's western boundary is the shore of the new lake.

The totally wooded site slopes from south to north with a vertical drop of nearly 100'. Large areas of the site are in a slope condition of between 10 and $20 \%$. The parcel is bi-sected by a major drainage course running southeast to northwest that divides the site into nearly equal halves.

\section{Land Use Program}

Parcel 22 had not been conveyed to a builder when this study was conducted. The Partnership had prepared a schematic plan for the site, however, before we began our study. The program called for a combination of garden and townhouse units. The yield reflected in the developer's schematic site plan was 252 garden units and 172 townhouses. The parking ratio's used $(1.68 /$ du for gardens and $2.10 /$ du for towns) resulted in 800 parking spaces overall.

\section{Business Plan}

The developer intends to convey Parcel 22 to a builder. The presumed sale basis will be the yield, or number of units, that can be constructed given zoning and site constraints.

4. The added cost to utilize the water-toair heat pump system is approximately $\$ 725,000$. The annual savings in energy costs for heating and cooling are approximately $\$ 298,000$, a return of 41 percent per year. We estimate that 90 percent of the heating and cooling savings relate to the heat pump system.

5. The overall reduction of gas consumption related to the use of the Town Center is estimated at 41,000 gallons per year.

\section{Base Development Plan and Energy Considerations}

The developer's base plan attempted to maximize the number of units on the site. The building pads were pushed as close to the perimeter of the site as possible and little or no consideration was given to the amount of tree cover that was sacrificed or the amount of earthwork required to handle the road and building arrangement. The resulting fill requirement was nearly $7000 \mathrm{cu}$. yds. per acre of which $3700 \mathrm{cu}$. yds. would have to be borrowed.

The building pads were arranged in relationship to the road alignments which produced a low percentage of north-south orientation. In addition, less than one acre of the existing tree cover was preserved, removing most of the natural shade and screening potential of the parcel. 


\section{Energy Conserving Solutions}

A fundamental problem with the Base Plan, in our opinion, was the excessive fill requirements needed to produce the high yield. This was especially a problem in the townhouse section where topography was being severely altered. Before attempting to adjust the Base Plan to deal with energy issues we tested the site plan and found that by reducing the number of townhouse units slightly we could save considerable earthwork costs. We therefore decided to settle for a reduced yield in the energy plan believing that overall development economics would support this approach. This is discussed more fully later on.

The energy conserving plan substantially changed the orientation of the buildings. All but one of the garden buildings was given a north-south exposure while 75 percent of the townhouses could be similarly treated. Overall paving was reduced by slight reductions in parking ratios, some road shortening and a reduced width for road paving. As many buildings as possible were sited for solar advantage and a full acre of existing vegetation was retained in strategic locations to protect the units from winter winds and summer sun.

As with the other study parcels, we tested the energy saving potential of using water-to-air heat pumps and a variety of water saving devices.

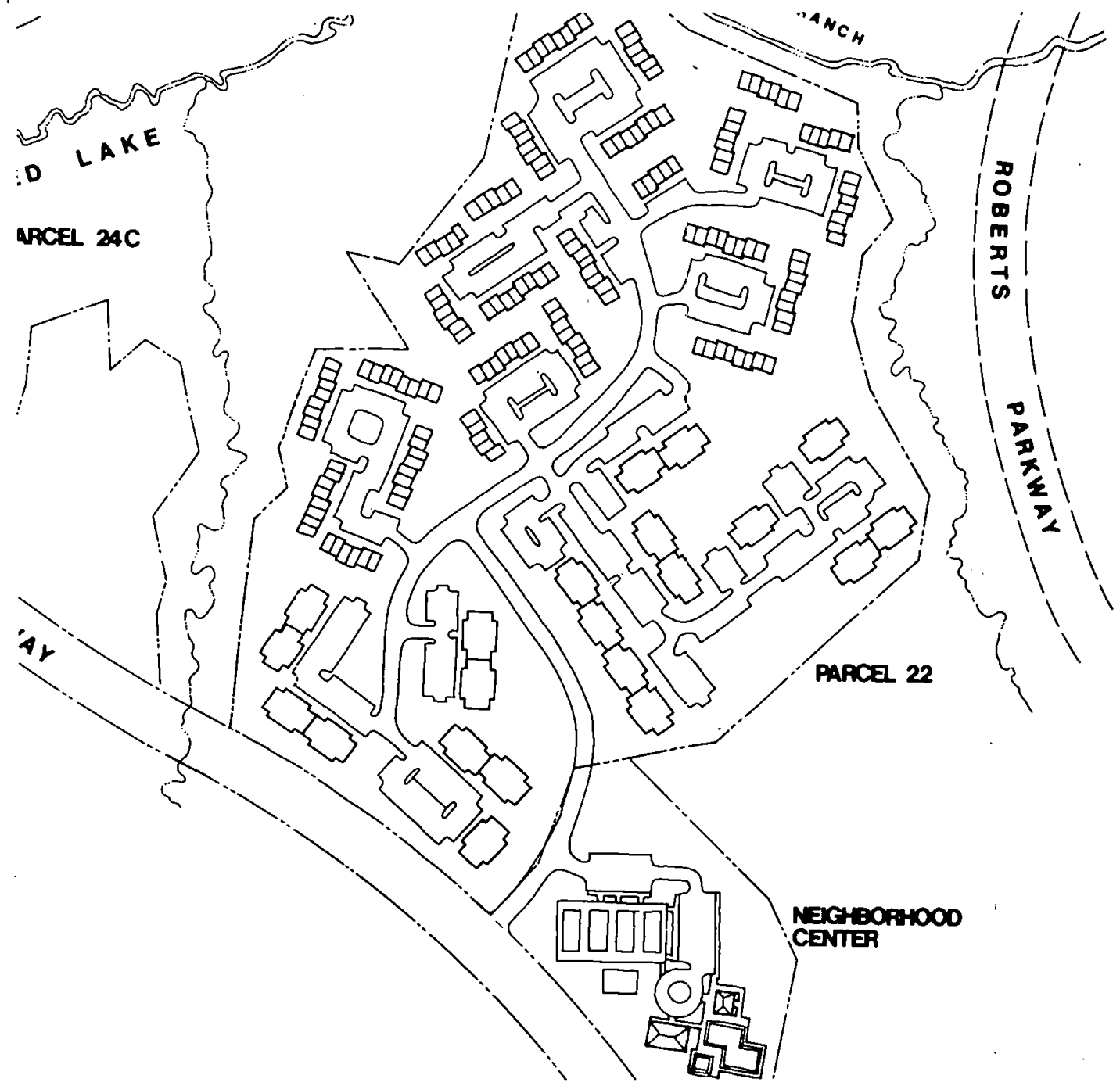

\section{Energy Savings Potential}

The reduction in gasoline usage that can be projected for the energy plan is almost entirely related to the fewer stops required. Just the removal of three of the original eleven stopping situations causes a 25 percent reduction in fuel consumption at intersections. On a site of this size and with the density involved this savings could amount to as much as 6,500 gallons of gasoline per year.

The water usage of Parcel 22 can be cut as much as 40 percent with the use of the various inexpensive devices discussed elsewhere. That's up to $15,000,000 \mathrm{gal}-$ lons of potable water per year, or 40,000 gallons daily. Hot water use in a site the size of Parcel 22 can consume as much as $10 \times 10^{9} \mathrm{BTU} / \mathrm{yr}$. The cost of providing this service will approximate $\$ 119,000$ per year or about $\$ 280$ per unit per year if conventional plumbing fixtures are used. This could be dropped to about $\$ 176$ per unit per year with a nominal investment in special showerheads, faucets and so forth.

Heating and cooling of the Parcel 22 dwellings will cost $\$ 158,000$ anually (about $\$ 370$ per unit) without an efficient heat pump system and proper building orientation. This can be reduced to about $\$ 75,000$ a year (about $\$ 180$ per unit) with the planning techniques and equipment tested in the study.

Figure 7. Base Plan • Parcel 22

\section{The Cost of Energy Conservation}

When the conveyance of a development parcel is based on its dwelling unit capacity, which is typical in the industry, the seller will obviously presume the maximum number of lots or units allowed by zoning. Zoning densities, in turn, are usually established assuming a flat and featureless site. When developing a site such as Parcel 22 the builder/developer will instruct his engineer to achieve the full yield since he "paid" for that number of units. The result, not surprisingly, can be extensive abuse of the land's natural features. As we discovered in our study of this Parcel, maximum yield and maximum profit are not always the same.

The Base Plan with 424 units required over $250,000 \mathrm{cu}$. yds. of fill (over half from offsite) costing $\$ 900,000$, or more than $\$ 2,100$ per unit. By pushing development to the furtherest edges of the site the cost of roads, utilities and drainage added $\$ 3,400$ to the land development process. The total cost of all land improvements was estimated to be in excess of $\$ 2.5$ million. That amounts to $\$ 5,900$ per dwelling unit or $\$ 64,000$ per gross acre. The Energy Plan sited the buildings and roads to relate to the terrain and kept away from the more difficult slope conditions. The development pattern grouped the buildings closer to the central service road staying away from the perimeter of the site. In some cases, particularly in the townhouse areas, parking lots were sited to further shorten the length of service roads.

The Energy Plan could not yield the full 424 units intended for the parcel. The full garden apartment program was obtained but the townhouse yield fell short by 14 units. Although only a 3 percent reduction in yield, this would frequently be considered unacceptable in the industry. This view is challenged by the development economics however. Earthwork was reduced to only $\$ 329$ per unit (a savings of $\$ 1,770$ per unit) by cutting into existing slopes rather than using borrow to level the site. Road, utility and drainage costs were reduced to $\$ 2,900$ per unit, a savings of $\$ 500$ each. Total site development costs are estimated at just under $\$ 1.6$ million or $\$ 3,900$ per unit (\$41,000 per acre). 
What does this discussion of land development practices have to do with energy conservation? Surprisingly, quite a bit. The Energy Conserving Plan was designed not to reduce development costs, but future energy consumption by the project's residents. The savings of $\$ 966,000$ in earthwork, roads and utilities was largely incidental to the exercise. It was not accidental, however, since shortened road (and, consequently, utility lines) lengths and retention of slopes and vegetation were the goals of the energy plan. Planning to this criteria inevitably reduces improvements costs. It also tends to reduce the site's yield in some cases. There is no formula for predicting the relationship between costs and yield nor are the results likely to always be as impressive as in Parcel 22. It appears from this test case, however, that developers and builders would benefit from using energy associated criteria when directing their site planning consultants.

The other cost factors related to reducing energy costs on Parcel 22 are well within the budget of homebuilders and buyers. The water saving devices required in each dwelling are all on the market and their cost per unit over conventional fixtures is nominal. The water-to-air heat pump system will require on-site wells (a closed system using potable water may also be used) and will add an estimated $\$ 290,000$ to the overall cost of the project. That is approximately $\$ 700$ per unit. Partially off-setting this cost is a $\$ 100$ per unit savings in space equipment conditioning costs.

\section{Summary}

1. It is estimated that the 424 residential units in the Base Plan will consume $31.56 \times 10^{9} \mathrm{BTU} / \mathrm{yr}$. This includes: a) heating $=7.52 \times 10^{9}(23 \%)$; b) cooling $\left.=5.85 \times 10^{9}(18 \%) ; c\right)$ lighting $=1.83 \times$ $10^{9}(5 \%)$; d) appliances/equipment $=$ $6.26 \times 10^{9}(19 \%)$, and hot water $=$ $10.10 \times 10^{9}(35 \%)$.

2. The Energy Plan could reduce the entire consumption of energy usage by buildings to an estimated $21.06 \times 10^{9}$ $\mathrm{BTU} / \mathrm{yr}$. This 33 percent reduction is attributable to: a) a $47 \%$ cut in heating and cooling consumption due to site planning advantages and the waterto-air system; and b) a $41 \%$ savings in hot water usage related to the use of various appliances and plumbing fixtures.

3. The future residents of the parcel stand to use 6500 less gallons of gasoline each year as a result of fewer stops and interruptions in the local street system. That amounts to 15 gallons or about one tankful per dwelling unit per year.

\begin{tabular}{|lrrrr|}
\hline \multicolumn{4}{c}{ Conventional Plan } & \multicolumn{2}{c|}{ Energy Plan } \\
\hline Item/Description & Quantity & $\begin{array}{c}\text { Total Price } \\
(\$ 000)\end{array}$ & Quantity & $\begin{array}{c}\text { Total Price } \\
(\$ 000)\end{array}$ \\
\hline Site preparation & 33 ac. & $\$ 83$ & 35 ac. & $\$ 83$ \\
Earthwork & 263,000 C.Y. & 897 & 90,000 C.Y. & 135 \\
Erosion control & Lump Sum & 39 & Lump Sum & 36 \\
Site drainage & 4590 L.F. & 197 & 2960 L.F. & 131 \\
Sanitary sewer & 13,925 L.F. & 241 & 13,950 L.F. & 194 \\
Water line & 7,950 L.F. & 146 & 8350 L.F. & 139 \\
Pavement & 49,838 S.Y. & 716 & 38,988 & 574 \\
Curb/gutter & 17,500 L.F. & 140 & 18,150 L.F. & 145 \\
Shade trees & 401 & 70 & $\cdot$ & 686 \\
Evergreen trees & 50 & 4 & 59 & 120 \\
Shrubs & 424 & 8 & 424 & 5 \\
\hline
\end{tabular}

$\$ 2,540$

$\$ 1,575$

Energy Plan Savings $(\$ 000) \$ 966$

$\begin{array}{cc}\text { Greatest Savings: } & (\$ 000) \\ \text { Earthwork } & \$ 761 \\ \text { Pavement } & 141\end{array}$

4. The anticipated reduction in water consumption by the project amounts to a savings of $4.0 \times 10^{9} \mathrm{BTU} / \mathrm{yr}$. for water and waste treatment operations. The resulting savings to the public utility cost of serving the project would approximately $\$ 30,000$ per year.

5. The cost of producing a finished lot and dwelling on Parcel 22 is reduced by $\$ 2,000$ for site improvements, and increased about $\$ 600$ for the water-to-air heat pump systems, the net savings of $\$ 1,400$ per unit amounts to nearly $\$ 600,000$ for Parcel 22. 


\section{Neighborhood Center}

\section{Site Conditions}

The 6.2 acre neighborhood center lies adjacent to the southeast corner of Parcel 22 along the Burke Centre Parkway. The wooded site is dominated by a high level plateau which occupies the western third of the site. The remainder of the site slopes to the northeast towards a tributary of Sideburn Branch adjacent to Roberts Parkway. Several areas in the northern portion of the site have slopes of $20 \%$ or more with the balance of the parcel having slopes of between 5 and $10 \%$.

\section{Land Use Program}

The Center is a conventional recreation center that many developers include today in their residential projects. The program envisions a full-size community swimming pool with an $1800 \mathrm{sq}$. $\mathrm{ft}$. bathhouse, a smal Community Building of 4,000 sq. ft., 4 Tennis Courts and a parking lot for 50 cars.

\section{Business Plan}

The Burke Centre Partnership will develop the Neighborhood Center and convey the completed project to the community association for future operation. The development schedule has not yet been set.

\section{Base Development Plan and Energy Considerations}

A schematic site plan for the Center has been prepared by the developer and was used as the Base Plan for this study. This Plan contained several features that potentially involved excessive energy consumption. The pool, bathhouse and community building were fairly remote from the access road to the site. This created a long service drive to the parking lot. The community center and bathhouse were shown as two individual buildings producing extensive exterior wall area for the amount of enclosed space. In addition, the buildings were poorly oriented for prevailing solar and wind conditions.

\section{Energy Conserving Solutions}

Although the site contains some pronounced slope conditions it was possible to relocate the Center closer to the access road without incurring additional earthwork costs. The building space was combined into one structure with reduced exterior wall area and the building was located on the service road side of the pool to further shorten the distance to the parking lot. It was a simple matter to align the small structure on a north-south axis. Finally, a tree planting program was used to increase wind screening.
In addition to the site planning modifications the use of water conserving devices was employed as was the assumption that a water-to-air heat pump would be used.

\section{Energy Savings Potential}

The gasoline savings realized from shortening the service road are, of course, small in terms of overall consumption by the community. Nevertheless, even the reduction of 100 feet in the road length should produce a savings of 50 gallons or more o gasoline a year, given the anticipated use of the Center.

The use of the water-to-air heat pump and the consolidation of the building space with proper solar/wind orientation produces an estimated savings of $114 \times 10^{6} \mathrm{BTU} / \mathrm{yr}$. or $\$ 949$ in energy costs for heating and cooling operations. The use of the water conserving devices, particularly in the bathhouse, should lower the cost of hot water by as much as $\$ 1,250$ per year. The amount of water used is cut in half by the shower heads and restricting valves which, of course, has a substantial effect on water and waste treatment costs.

\section{Costs of Energy Conservation}

Table 8 summarizes the comparative cost for land improvements in the two plans. The Appendix Document shows the detailed cost take-offs for each. The shortening of the service road and reduction in the utility line runs resulted in a savings of $\$ 42,000$ in total costs, a reduction of 27 percent from the Base Plan. An add-on of about $\$ 8,500$ was then made for additional shade and evergreen trees to help control the environmental impact on the buildings. The net savings were thus reduced to $\$ 34,000$, or about 22 percent.

Additional cost savings were achieved by reducing the unit cost of the space conditioning equipment and thus the total installation price from $\$ 8,800$ to $\$ 5,600$.

In addition to the trees, the other direct cost associated with the energy conserving plan is for the well $(\$ 3,500)$ and the piping $(\$ 500)$ associated with the water heat exchange system in the building.
Table 8. Neighborhood Center Site Development Costs

\begin{tabular}{|c|c|c|c|c|}
\hline \multirow[b]{2}{*}{ Item/Description } & \multicolumn{2}{|c|}{ Base Plan } & \multicolumn{2}{|c|}{ Energy Plan } \\
\hline & Quantity & $\begin{array}{l}\text { Total Price } \\
(\$ 000)\end{array}$ & Quantity & $\begin{array}{c}\text { Total Price } \\
(\$ 000)\end{array}$ \\
\hline Site preparation & 4.8 A.C. & $\$ 12$ & 4 A.C. & $\$ 10$ \\
\hline Earthwork & 7130 C.Y. & 11 & 6100 C.Y. & 9 \\
\hline Erosion control & Lump Sum & 3 & Lump Sum & 2 \\
\hline Site drainage & 80 L.F. & 5 & 40 L.F. & 4 \\
\hline Sanitary sewer & 920 L.F. & 19 & 570 L.F. & 15 \\
\hline Waterline & 550 L.F. & 15 & 300 L.F. & 12 \\
\hline Pavement & 4815 S.Y. & 72 & 3080 S.Y. & 47 \\
\hline Curb & 1460 L.F. & 12 & 800 L.F. & 6 \\
\hline Shade trees & 42 & 7 & 85 & 15 \\
\hline \multirow[t]{2}{*}{ Evergreen trees } & - & - & 12 & 1 \\
\hline & & $\$ 154$ & & $\$ 120$ \\
\hline
\end{tabular}

Energy $P$ an Savings $(\$ 000) \quad \$ 34$

\begin{tabular}{lc}
\hline Greatest Savings: & $(\$ 000)$ \\
\hline Paverent & $\$ 25$ \\
Curb & 5 \\
Sanitary sewer & 4
\end{tabular}




\section{Summary Neighborhood Center}

Despite the small size and seasonal use of part of this complex we felt that studying the Center was of importance to our study. It is very common today for facilities of this nature to be constructed in suburban housing areas. The amount of energy savings that can be derived from the conservation measures we employed are relatively large and certainly worth the effort.
1. The initial capital costs are reduced by over $\$ 30,000$ despite the expansion of the tree planting program and the drilling of a well.

2. The transportation savings are too small to make a major statement. Yet, they are real and there is no good reason why they should be ignored.

3. The use of water conserving devices in the bathhouse should save as much as 200,000 gallons per year.
4. The costs for heating water in the neighborhood center and the bathhouse should be reduced by over 70 percent. We estimate that over $\$ 1,200$ per year could be saved on hot water services alone.

5. Heating and cooling cost estimates also came down by well over 40 percent (over $\$ 900$ per year) by using the water-to-air system and proper site orientation.

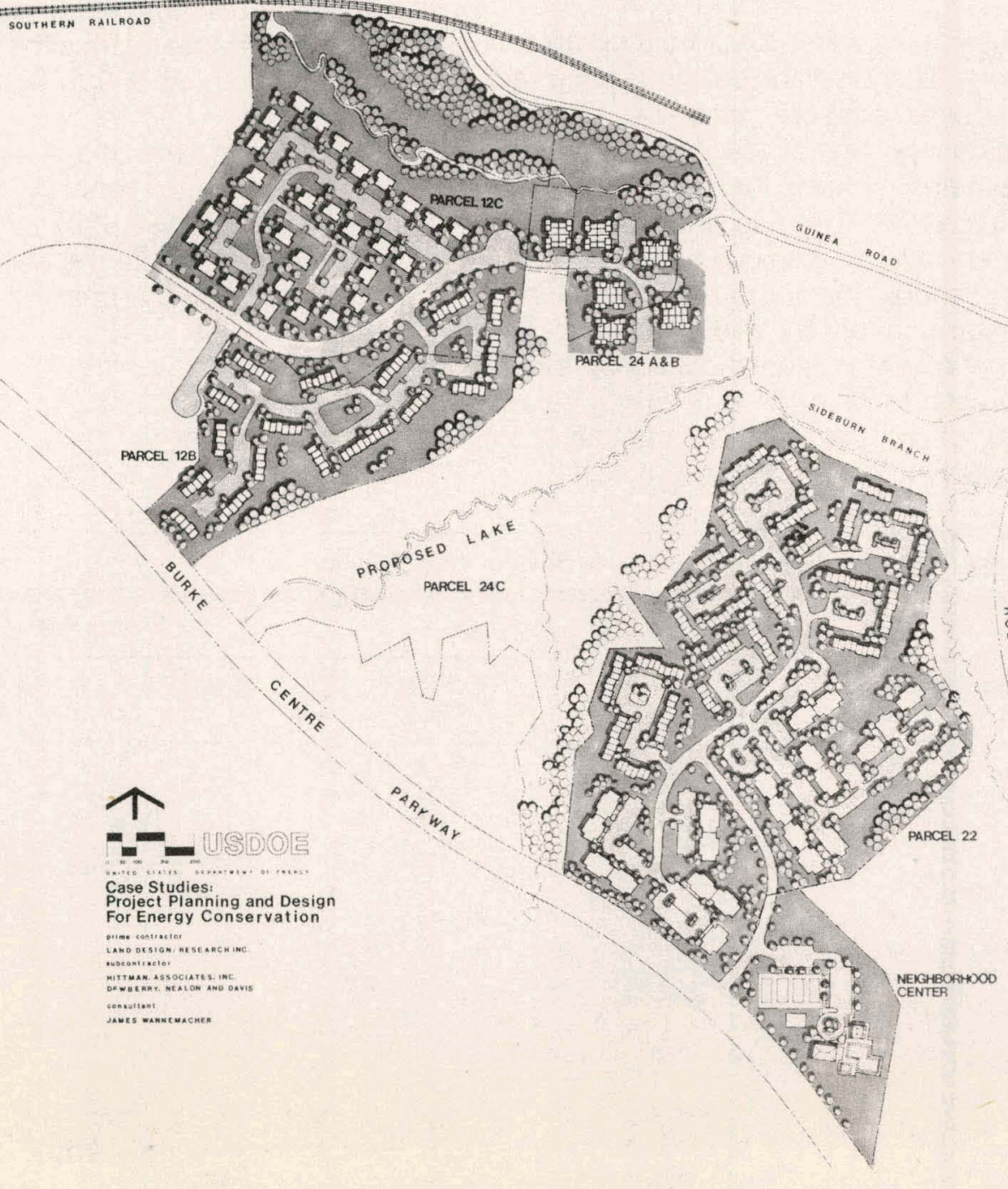

Figure 8. Base Plan of Study Area 


\section{Parcels 12 and 24}

There were several small bulk parcels designated for residential use that were available for our study purposes. These were re-planned in similar fashion to Parcel 22 and analyzed to determine the cost impact and potential energy savings. The results are included in the Appendix Document. The configuration of the building type programmed for Parcel 12C, the four-plex unit, limited the benefits from solar orientation. The four-plex units were sited so that the maximum glazing of the building occurs on the south to take advantage of the warming winter sun. The building overhangs on the east and west reduce the intensity of the summer sun on those walls. The four-plex structures were sited to reduce land development costs through shortened road and utility runs and minimized cut and fill operations.

Generally, the results obtained in these smaller sites reinforce the findings in Parcel 22 which is discussed at some length in the proceeding section. Land improvement costs were cut by 10 to 20 percent while potential savings in heating and cooling costs are about 44 percent. The inclusion of water-to-air pumps and water conserving devices within the homes should have a similar impact on a per unit basis.

See tables 19,20 or 22 from appendix for Parcels 12 and 24 


\section{Development of the Energy Conserving Plan}

\section{Inventory of the Base Plan}

Development of the energy conservation plan began with a thorough analysis of the base plan. These studies were conducted in an effort to identify and understand those elements which impart the use of energy, and to identify opportunities for improvement in the layout of the various building programs.

By understanding the land one can deal in a more sensitive way with modification of the site through grading, with retention of vegetation and natural drainage systems. Manipulation of these features can have an impact on micro-climates and significantly affect site development costs.

The climatic and topographic features were studied to determine their impact on the community layout plans and building types, and the opportunities they offered for energy conservation through modification of the base plan.

The various building types were analyzed to determine what additional energy saving opportunities were available at the individual unit level.

Together with the screened options an energy plan was systematically developed in order to take advantage of as many of these identified opportunities as possible. The physical layout of the various neighborhoods and building groups evolved through the influence of a combination of factors, i.e. costs, marketability of the final product, good site planning techniques, and regulatory restraints.

\section{Vegetation Retained}

Existing blocks of vegetation (meadows, fields, and trees) not only enhance local climate by modifying the extremes of hot and cold weather but the community plan that works with the topography to save these areas normally experiences reduced site development costs.

This exhibit identifies those areas retained in the base plan.

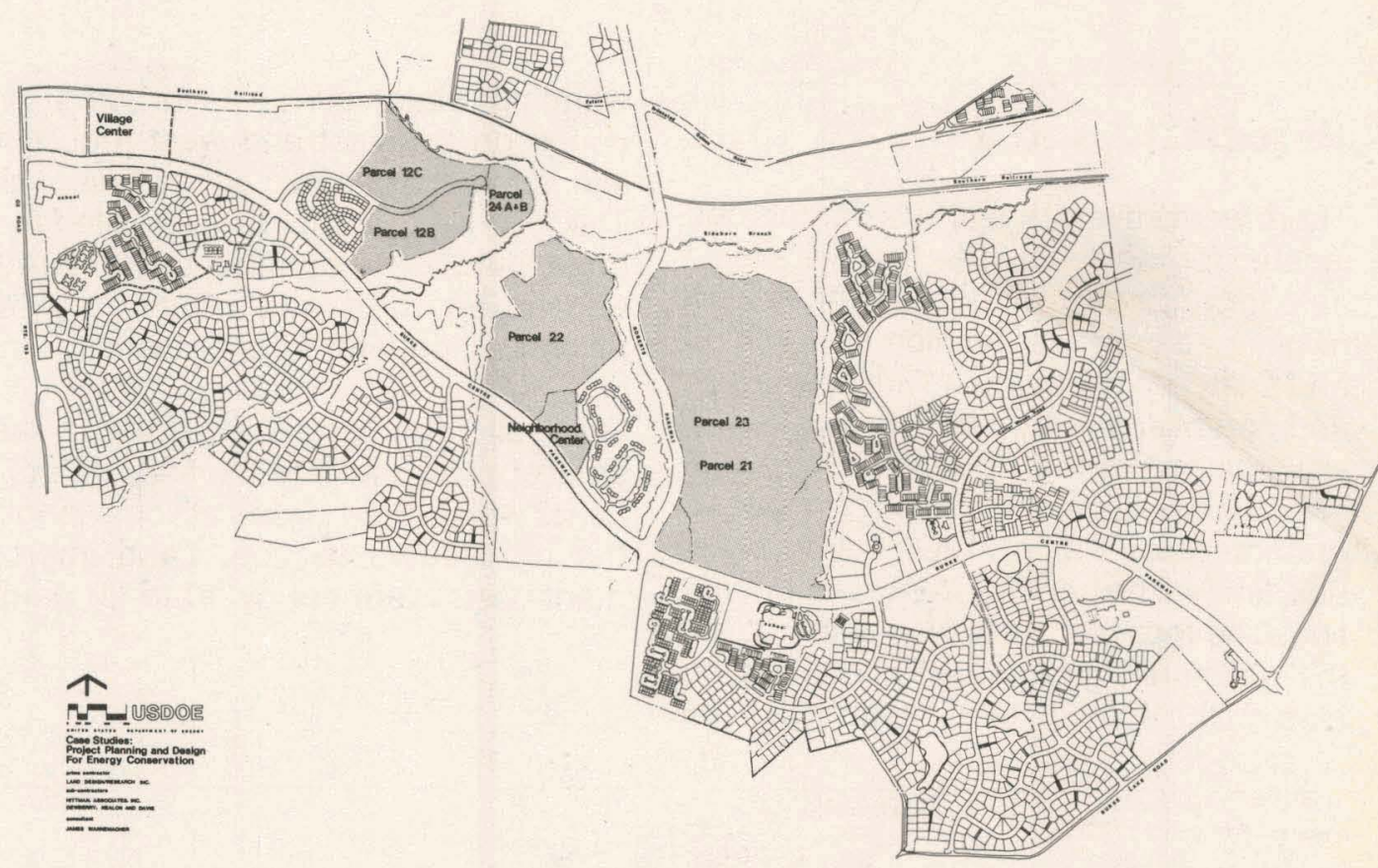

Base Plan of Study Area

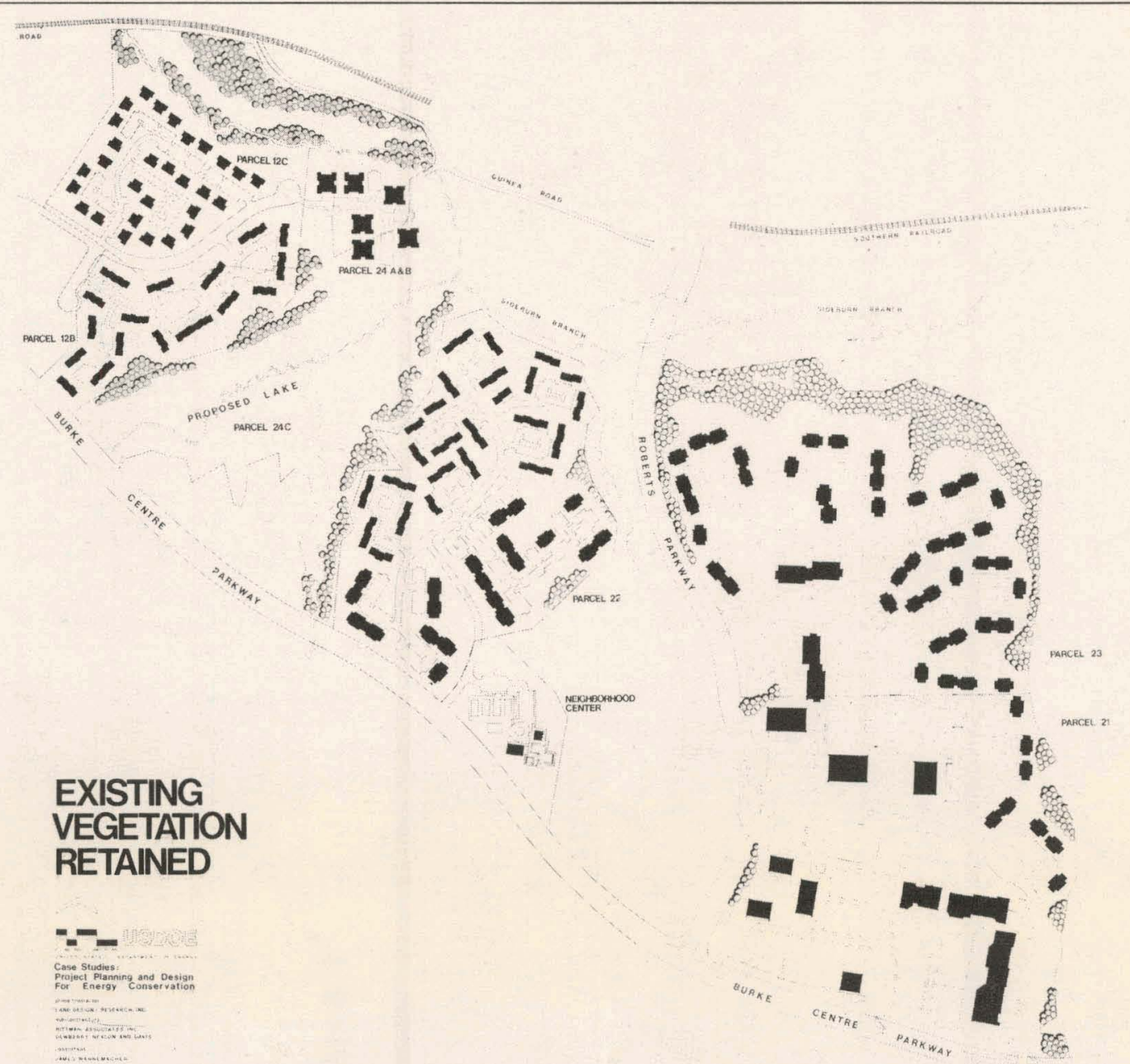

Figure 10. Base Plan - Existing Vegetation Retained 


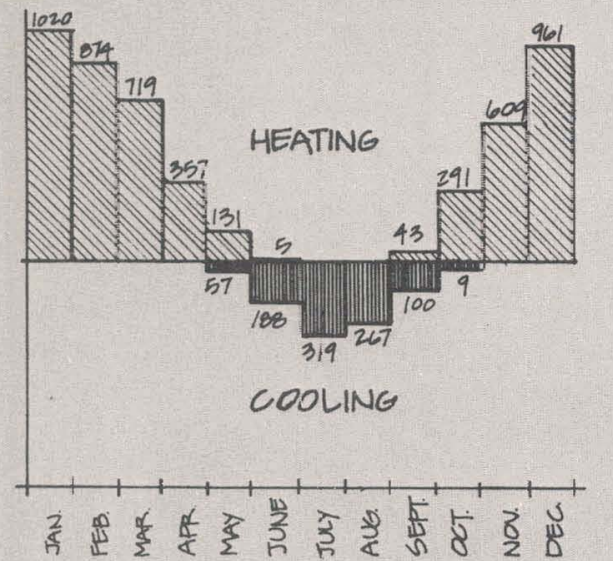

HEATING \& COOLING DEGREE DAYS 1976

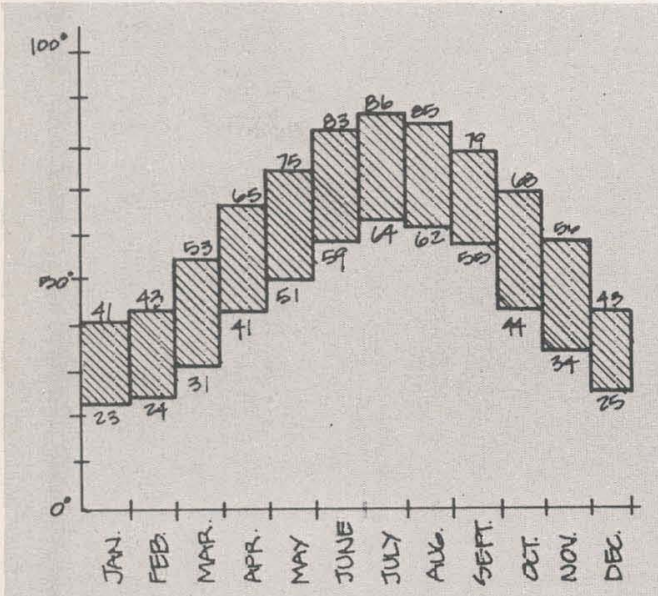

NORMAL HIGH/LOW MONTHLY TEMPERATURE 1941 - 1970

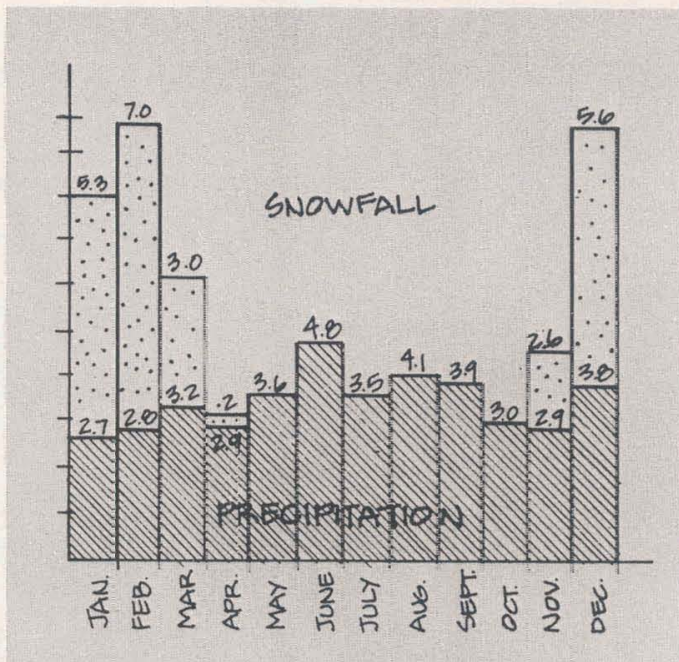

\section{AVERAGE MONTHLY PRECIPITATION $1963-1976$}

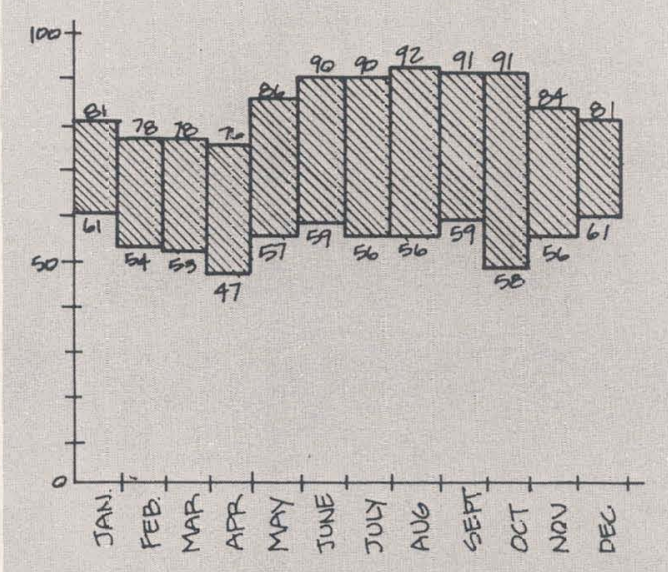

\section{AVERAGE MONTHLY RELATIVE HUMIDITY $1941-1970$}
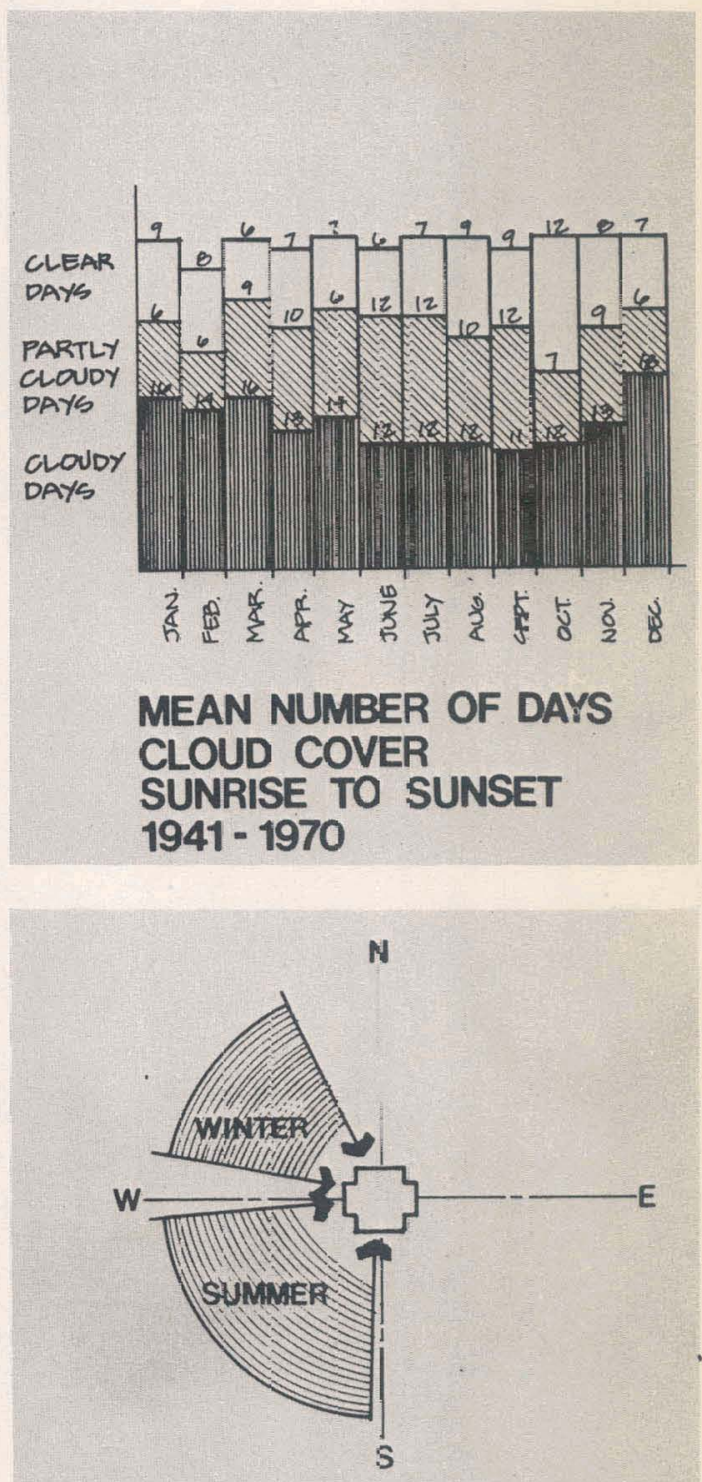

PREVAILING

WIND DIRECTION 1976

\section{Local Climatological Data}

Annual Summary With Comparative Data

\section{6}

WASHINGTON, D.C.

DULLES INTERNATIONAL AIRPORT

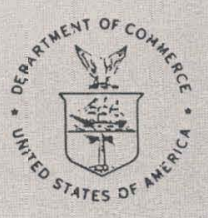

\section{Narrative Climatological Summary}

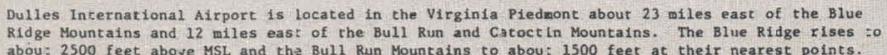

abous 2500 feet above MSL and tha Bull Run Mo
Abou:

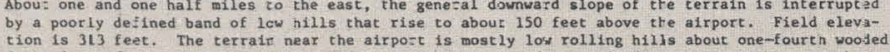

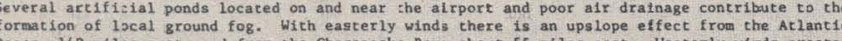
acean, $14 \mathrm{O}$ miles ast, and from the Chesapeaka Bay, about 55 miles east. Hesterly wirds create
silght foehn effect.

Location in the middie latituces, where che general atmospheric flow is from west co east, favors
continental cyje of climare with its four well defined seasoss. Fumpers are vara and at times

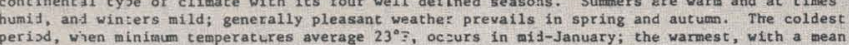
perid, wien minimum temperatures average 23
maximum of $87^{\circ} \%$, comes the last half of July.

Prectpitation is rather evenly distributed through the year. The greatest annual total of precipit
tion was 59.02 inches period was 11.88 inches, recorded during Tropical Scorm Agnes in June 1972 . The seascral snouf

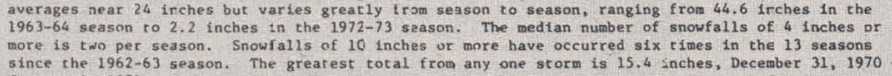

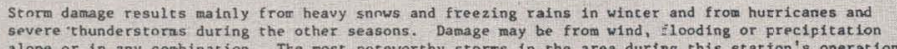

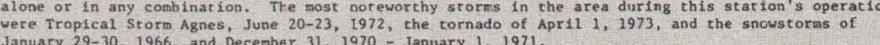

Prevailing winds are from the scuth except during the winter months when they are froo the northwe

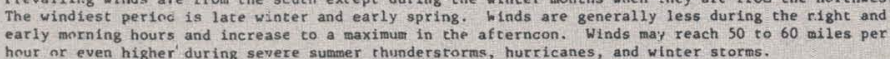

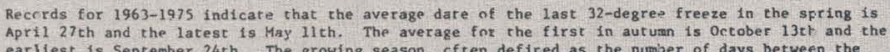
ear1iest is September $24 \mathrm{th}$. The growing season, cften defired as the numize.
last 32 -cegree freeze in spring and the first in autum, averages 169 days. 


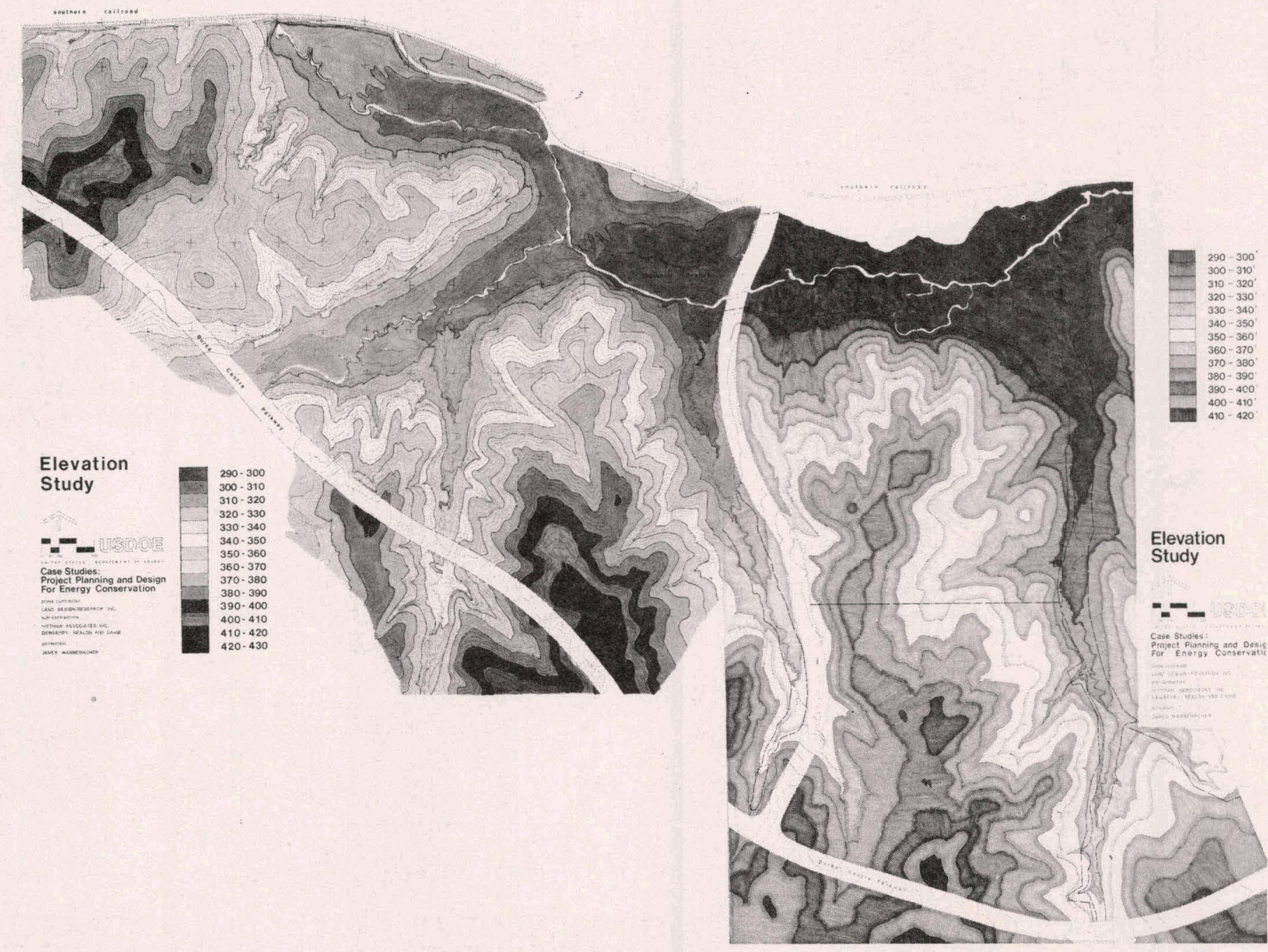

Figure 12. Elevation Study

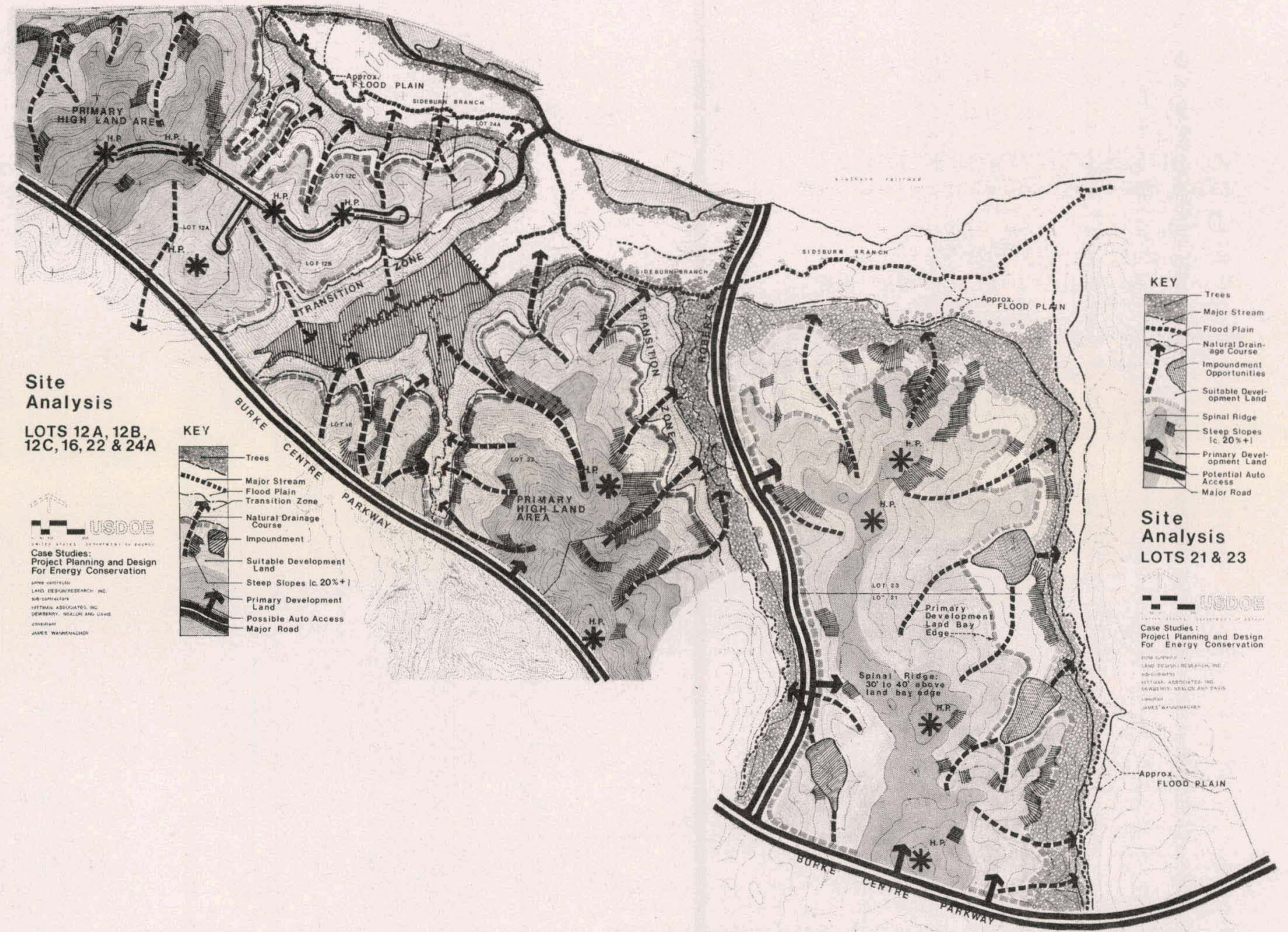




\section{Solar Impact Winter}

It is generally advantageous in this latitude $\left(38-39^{\circ} \mathrm{N}\right.$. Lat.) to orient the longest dimension of a building along the east-west axis. This will not only minimize the east/
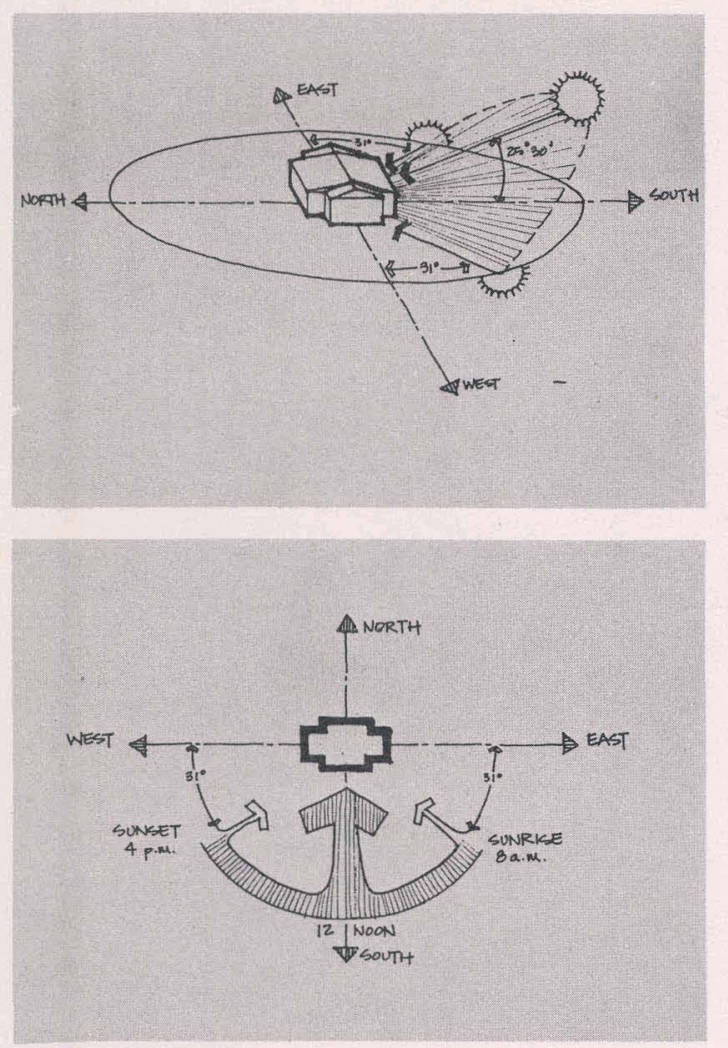

\section{Solar Impact Summer}

During the summer months the sun has its greatest impact on east and west facing, vertical surfaces. This is due in part to the low angle of the sun in the morning and late afternoon. As the sun climbs higher in the sky, during the middle of the day, the angle of incidence becomes less and less
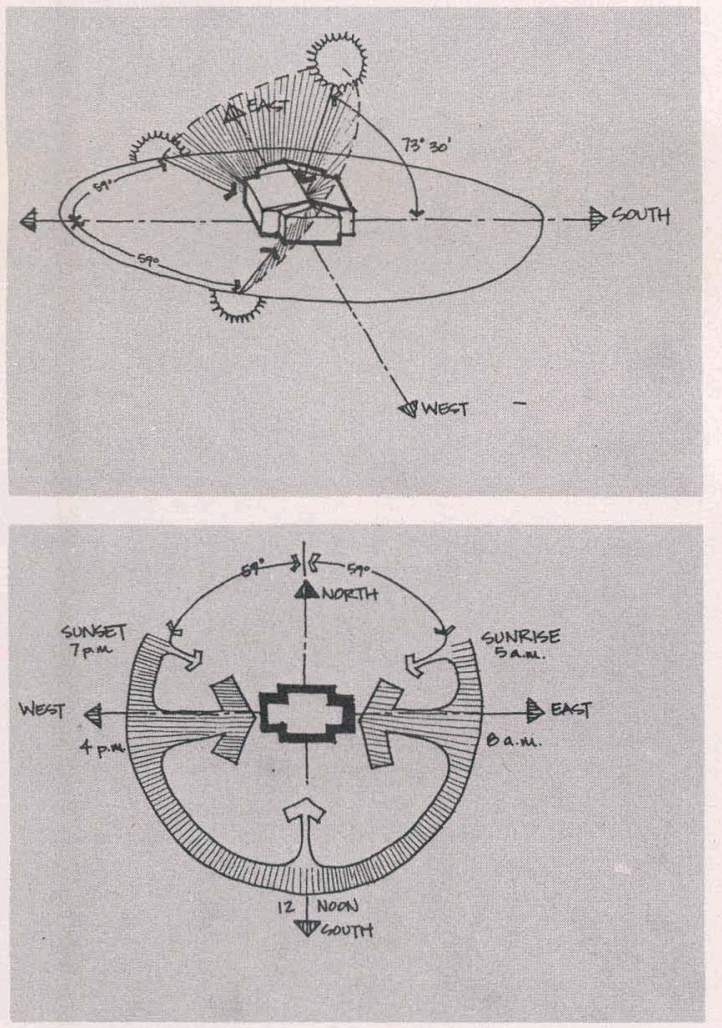

west wall surfaces, but will maximize the wall surfaces facing south.

This exhibit readily identifies those structures with the preferred orientation and helps in analyzing the feasibility of improving the orientation of others.
This configuration will provide the greatest opportunities for both passive and active solar utilization.

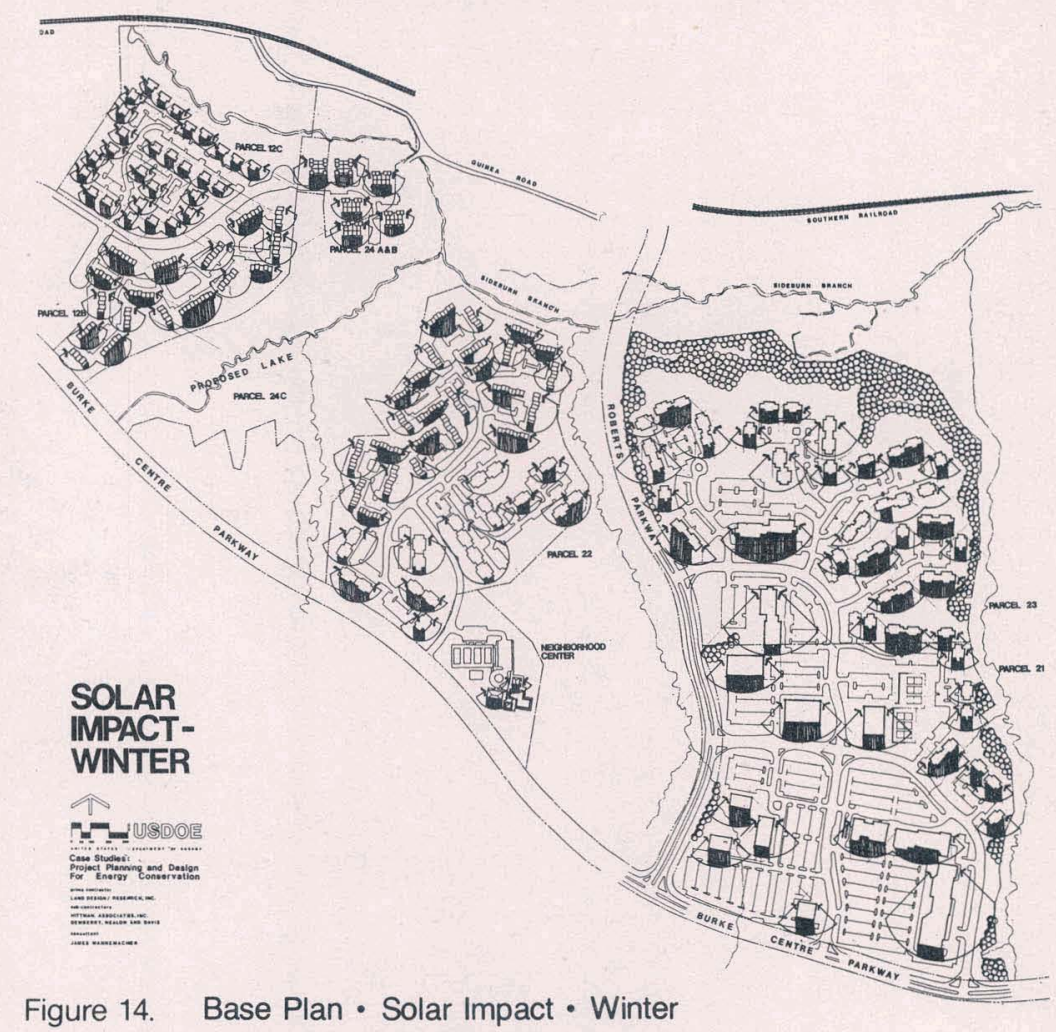

against south facing walls. The occurance of roof overhangs further reduces the solar impact on southern walls.

At this latitude the intensity of solar radiation is nearly twice as great on east and west facing walls as it is on south facing walls, during the summer months.
This exhibit allows the planner to calculate the surface areas of walls in different orientations, and manipulate the individua structures or groups of structures to re duce this negative energy impact. In addition it is helpful in identifying the most advantageous locations for shade trees as a further modifier of summer solar impact.

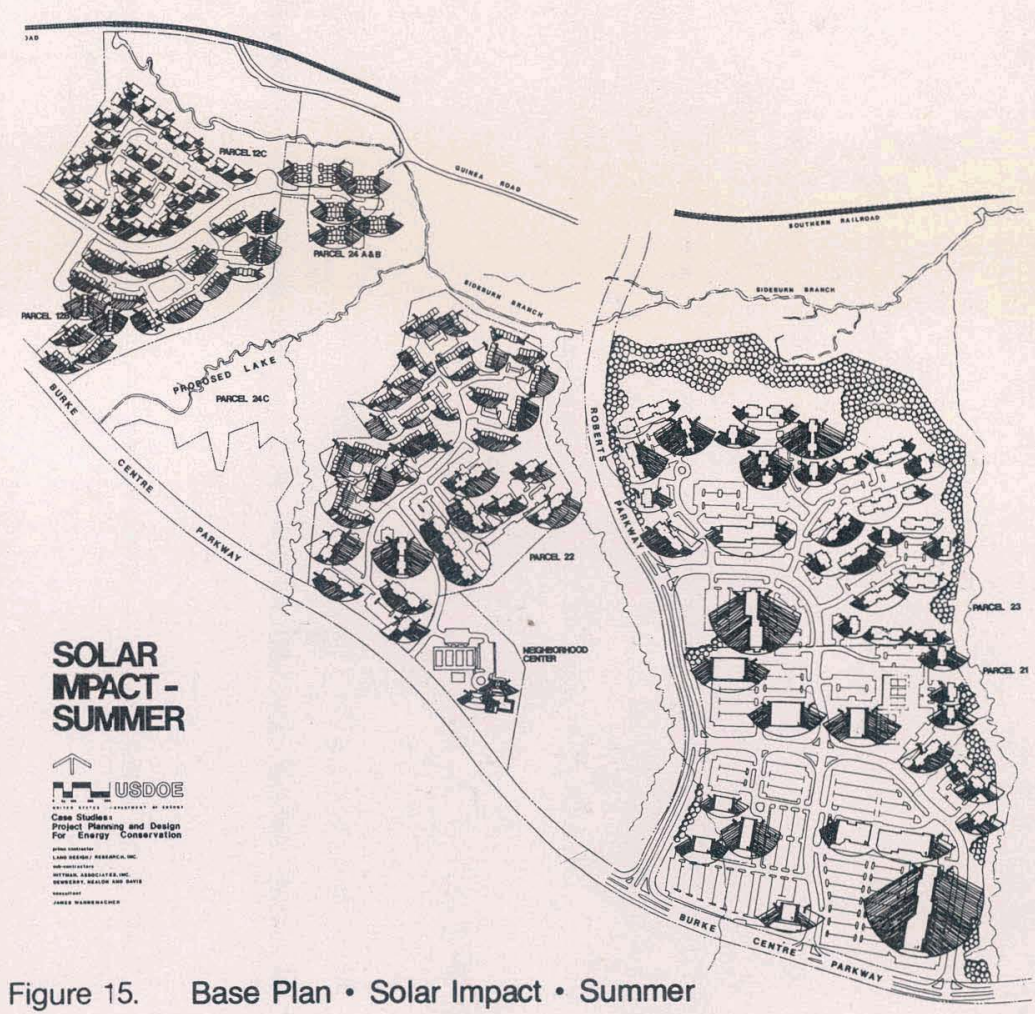

Figure 15. Base Plan - Solar Impact - Summer 


\section{Summer and Winter Shade}

These plans help in positioning structures in a positive manner related to their ability to provide shade. In the summer months, structures can be positioned to maximize the shade on heat absorbing paved surfaces, other (shorter) buildings and outdoor gathering places.
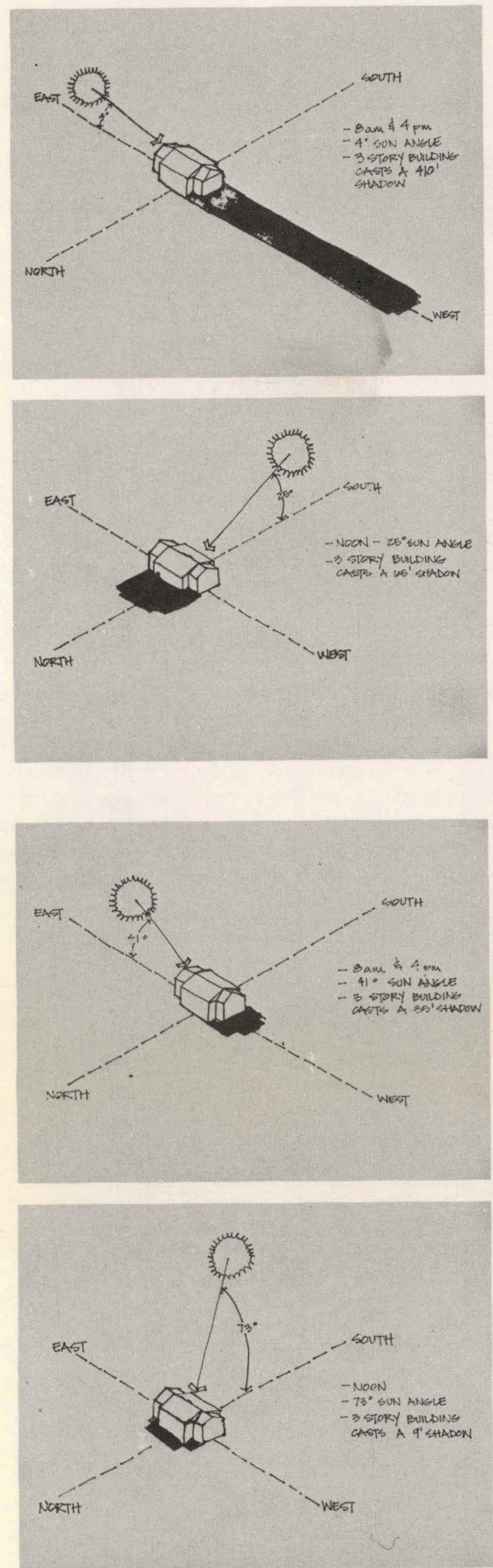

During the winter months building shadows become much more important in relation to solar accessibility for adjacent structures. A tall building could, in effect, exclude sunlight from reaching shorter structures in the north.
This exhibit enables the planner to recognize potential problem areas and adjust the plans to minimize the problems of winter shade and take full advantage of summer shade.
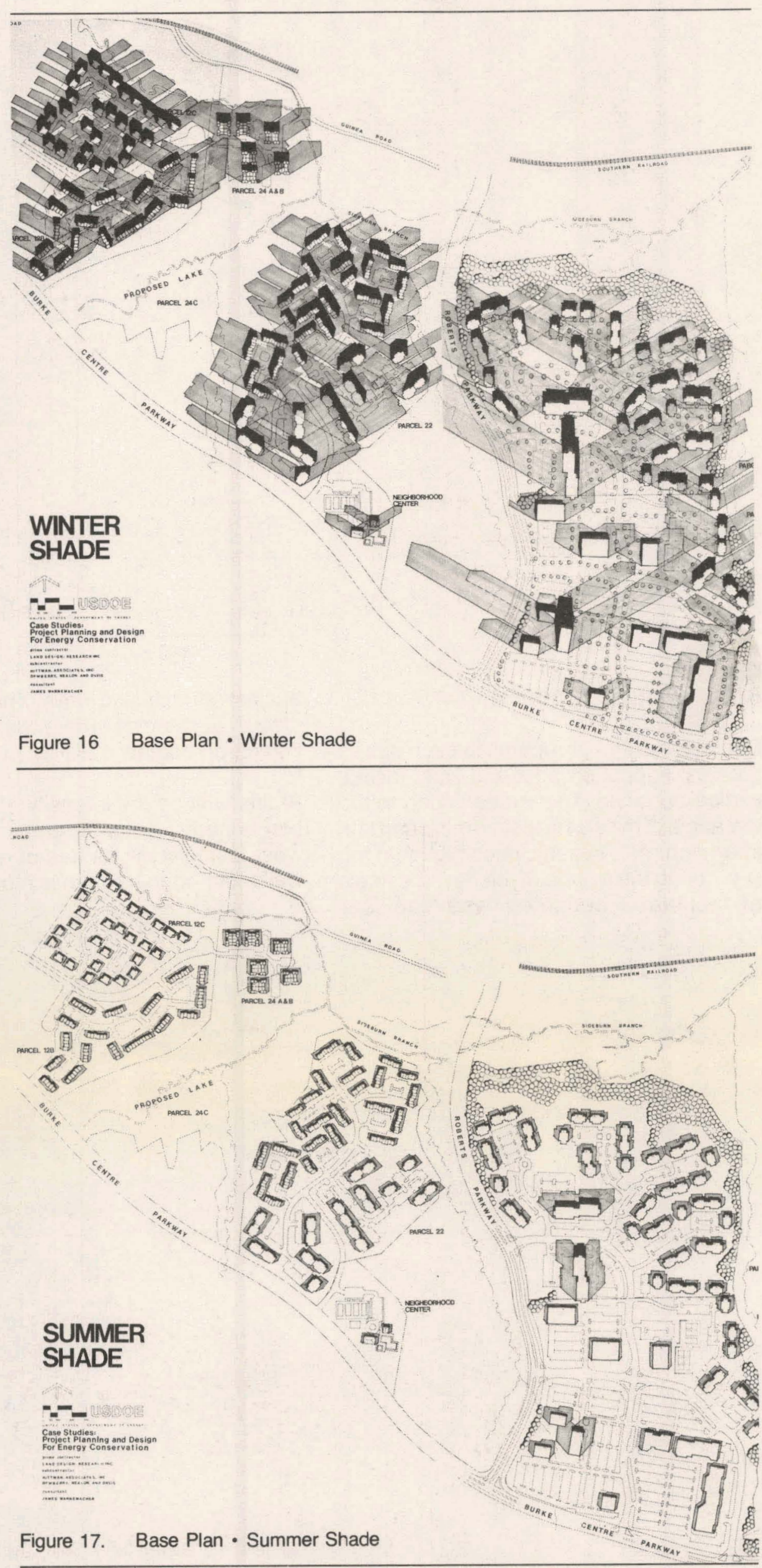


\section{Summer and Winter Wind}

In harsher climates the wind plays a significantly greater role in planning effectively for energy conservation. In this region the wind will have impact on micro-climates. Some thought to winter protection and enhancement of summer breezes, will help incrementally to decrease the energy needed for heating and cooling.
Natural and manmade earth forms, blocks of trees and buildings all can be used to create protective wind shadows in winter. Likewise, the proper arrangement of these elements can channel summer breezes and increase their velocity.
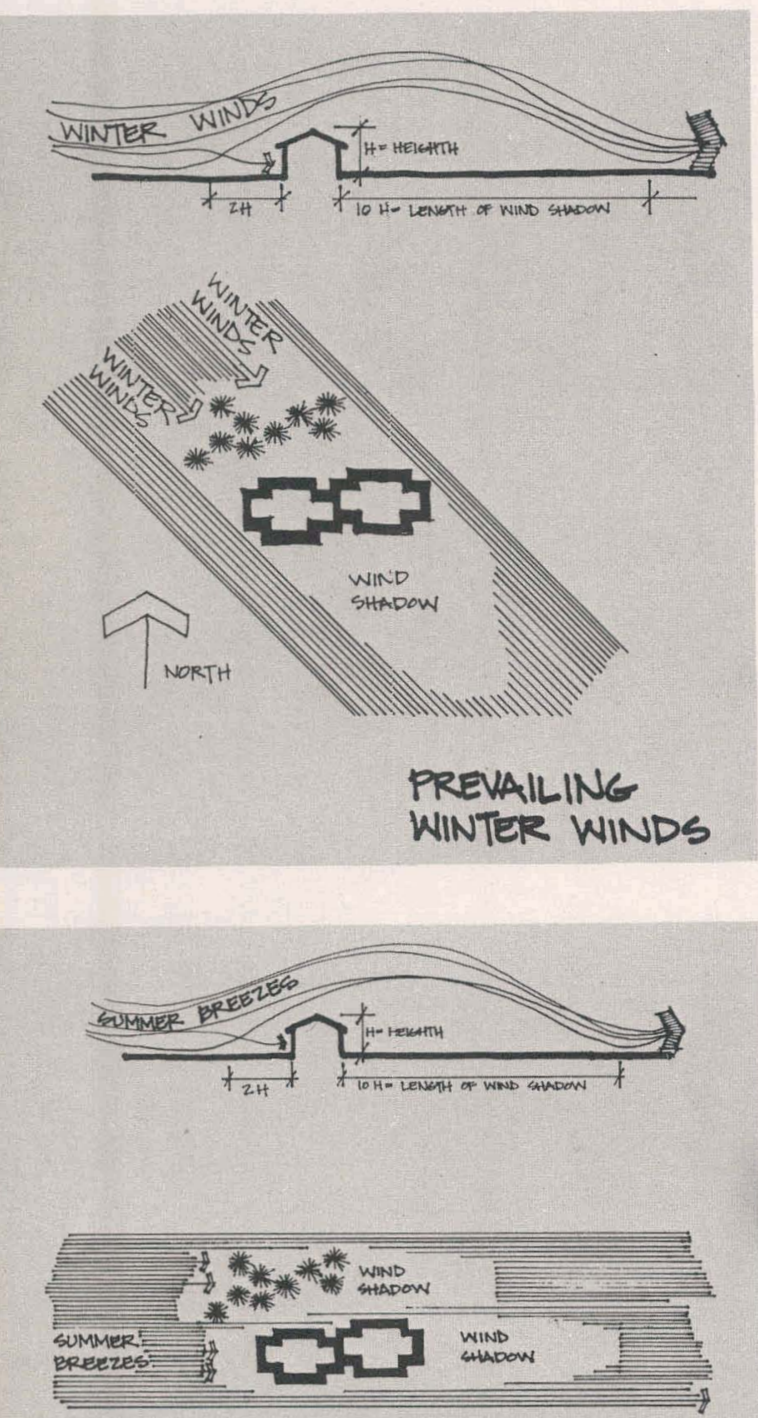

$\widehat{N}$

NORTH

SUMMER BREEZES

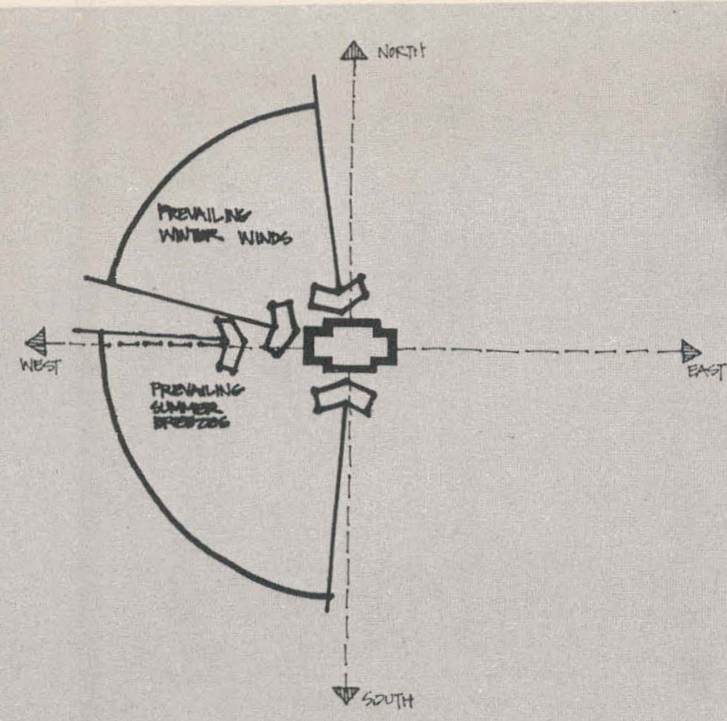

PREVAILING WIND DIRECTION

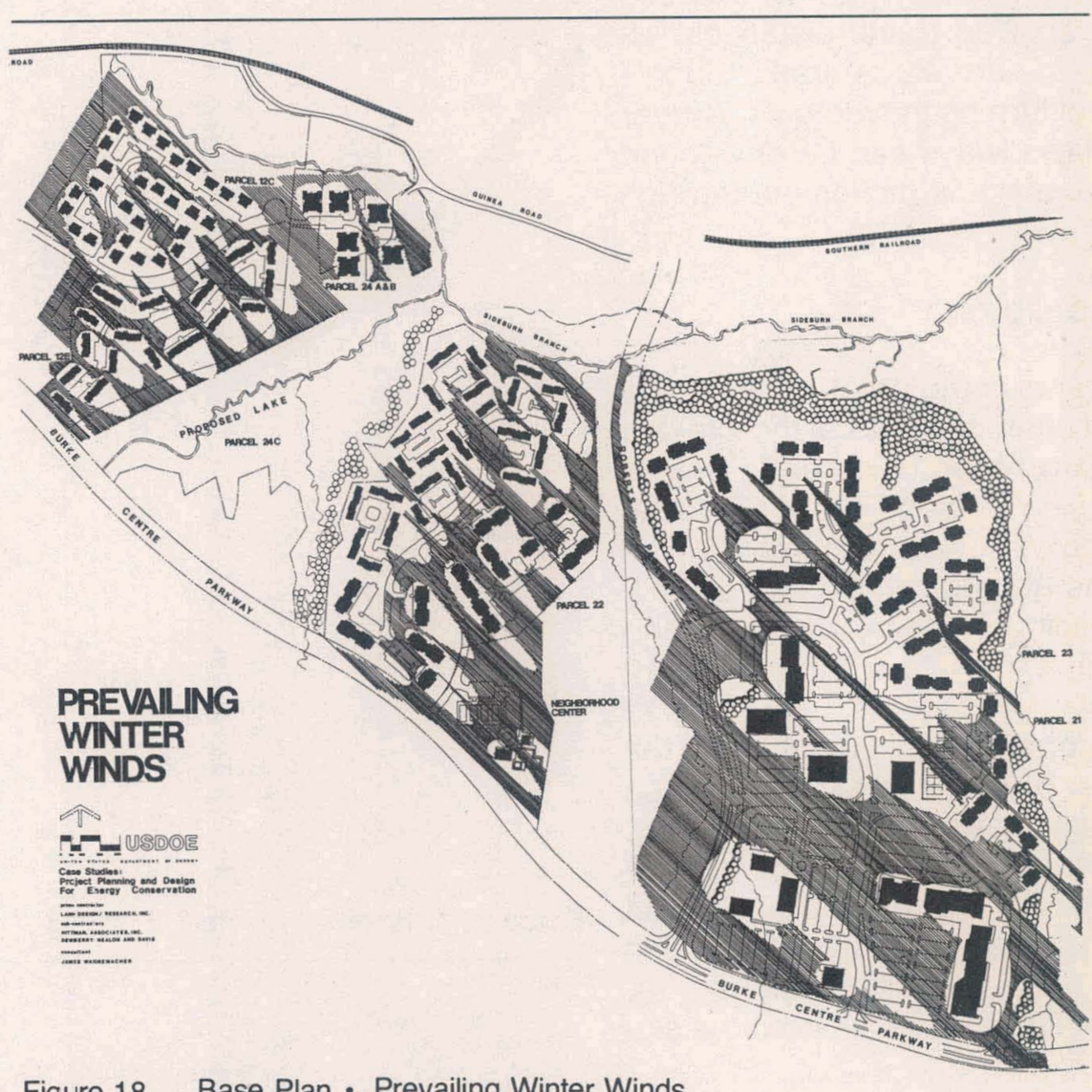

Figure 18. Base Plan - Prevailing Winter Winds

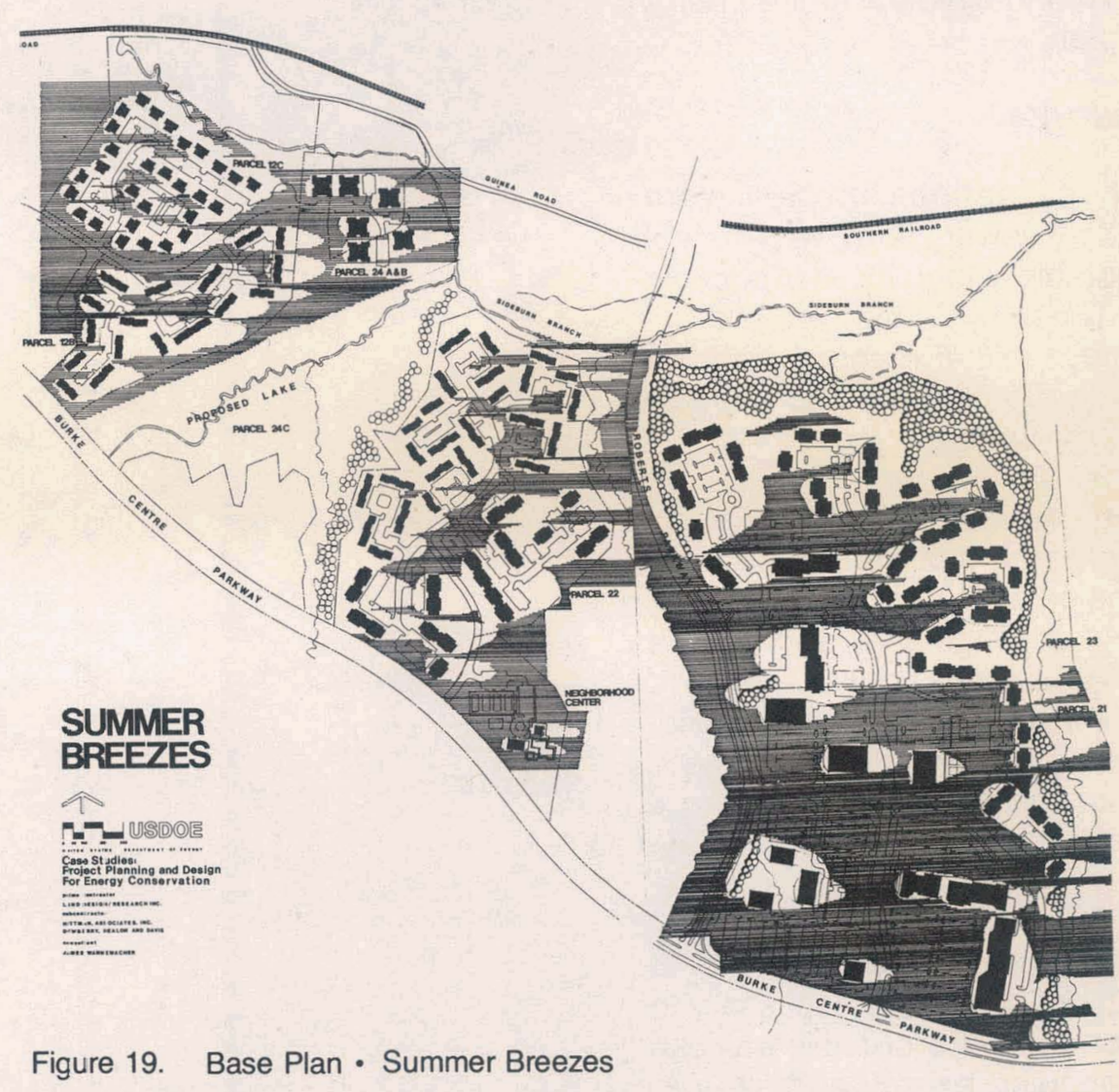




\section{Primary Traffic Pattern}

Since transportation represents the largest user of energy $(75 \% \pm)$ both within the study area and generated to and from the study area, it is important to understand how traffic moves through the community.

In this way alternate configurations can be explored to shorten travel distances, alleviate unnecessary stops, traffic signals and inefficient turning movements. A clear hierarchy of roadways can be developed to provide for efficient movement through the community.

\section{Impervious Cover}

This exhibit shows the amount of change in the run-off characteristics of the site due to construction of the community. Impervious cover includes all those surfaces which prevent the natural percolation of water into the ground, such as areas covered by buildings, roads, park-lots and pathways.

The area of impervious cover will affect the size and cost of storm water and erosion control systems needed in the community. In addition these surfaces absorb and reradiate heat which can negatively impact on micro-climates. The energy involved in the maintenance and ultimately the replacement of these surfaces is also a significant factor.

A major effort to reduce these surfaces was undertaken in developing the energy conserving plan.

\section{Utility Networks}

Layouts for the various utilities were studied; sanitary sewer, storm water, electricity and potable water. (See Appendix Document.) These systems were laid out in a fairly conventional manner, with the possible exception of electric service which is entirely underground.

Conversations with the utility company (VEPCO), indicated that trunk lines were in place for the entire Burke Centre project. According to their engineers, very little, if any, operational savings could be realized by altering the layouts of the various building programs. Although in certain cases line losses can be marginally reduced if that were the only criteria for program layout.

Modification of the plans does have impact on the quantity of utility runs necessary to service the community, and in this way can affect the embodied energy and site development costs.
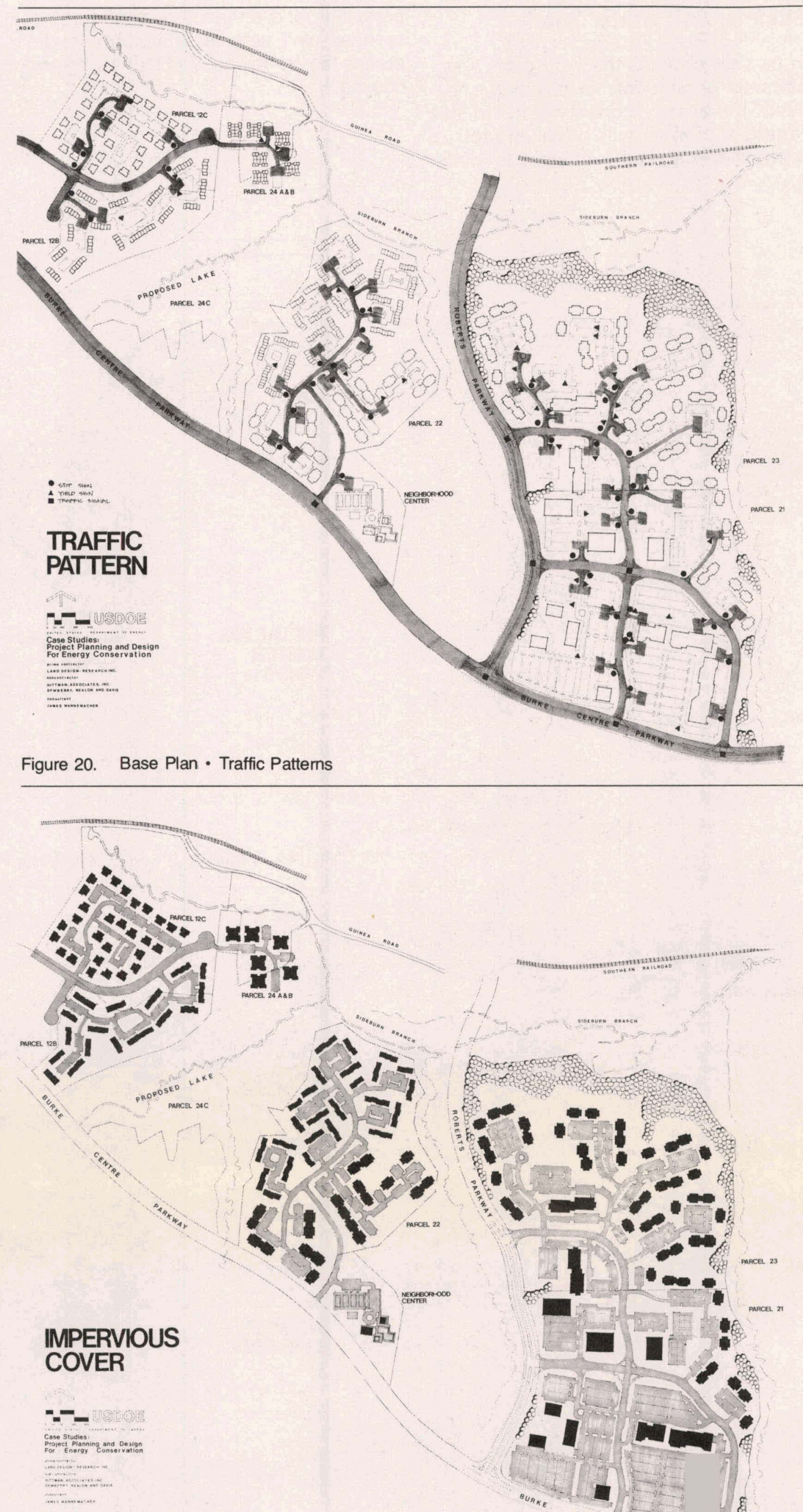

Figure 21. Base Plan - Impervious Cover 


\section{Site Data: Town Center Energy Profile}

\section{Base Plan}

The following is an example of data that was collected for each study parcel to aid the consultant team in preparing a base line energy profile. (See Appendix Document for breakdown on all Parcels.)

Acreage: 124.4 Ac.

Building Type and Number:

Office: 200,000 s.f.

Garden apartments: (12 du/building) $600 \mathrm{du}$ Hi-rise apartments: (168 du/building) $336 \mathrm{du}$

Commercial/retail: 100,500 s.f.

Commercial Recreation: 99,500

\section{Coverage:}

\begin{tabular}{|c|c|c|c|c|}
\hline & Acreage & $\begin{array}{l}\text { Square } \\
\text { Footage }\end{array}$ & $\%$ Total & $\begin{array}{l}\text { Type of } \\
\text { Material }\end{array}$ \\
\hline Buildings & 14.109 & 614,600 & $11.95 \%$ & \\
\hline Roadways & 6.083 & 265,000 & $5.15 \%$ & Asphalt \\
\hline Parking & 30.971 & $1,349,115$ & $26.22 \%$ & Asphalt \\
\hline $\begin{array}{l}\text { Sidewalk and pathways } \\
\text { (estimated) }\end{array}$ & 3.897 & 169,750 & $3.30 \%$ & Asphalt \\
\hline Undistrubed area & 11.178 & 486,925 & $9.45 \%$ & Natural cover \\
\hline Other & 51.862 & $2,259,109$ & $43.91 \%$ & Seeded grass \\
\hline
\end{tabular}

\section{Parking Spaces and Characteristics:}

Spaces $\left(9^{\prime} \times 20^{\prime}\right)$ lanes $-\left(24^{\prime}\right.$ minimum $)$

Office:

Commercial/retail:

Commercial/recreation:

Garden apartments:

Hi-rise apartments:

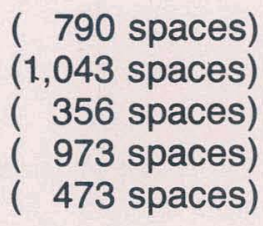

\section{Roadway Type, Length and Characteristics}

Collector streets - 4,800' length (50' width) - asphalt

Parking bay and access streets - (24' width) commercial $-11,875$ I.f.

Recreation $-3,175$ I.f. residential $-7,700$ Total $-22,750$ I.f.

\section{Electric Utilities System and Characteristics}

Buried cable - individual metering - contact VEPCO

\section{Storm Water System and Characteristics}

Range: $15^{\prime \prime}-54^{\prime \prime}$ rein. concrete pipe 11,040 I.f. of pipe

Conventional storm sewer system - curb and yard inlets

8 manholes

\section{Sanitary Waste System and Characteristics}

Conventional sanitary waste system to treatment plant

11,500 I.f. mainline; 3,400 I.f. connector

Site and Street Lighting and Characteristics (Site and Unit)

Commercial (parking lots, access streets) 1000 watt, $30^{\prime}$ pole

Collector street -1000 watt, $30^{\prime}$ pole; residential unit lighting by individual (no requirement); apartments - (parking lots only) 400 watt, $20^{\prime}$ poles,

$20^{\prime}$ poles $-225,30^{\prime}$ poles -240

\section{Water Supply System and Characteristics}

Standard potable water system using $3^{\prime \prime}, 8^{\prime \prime}, 12^{\prime \prime}$ pipes 20,260 I.f. pipe, 20 fire hydrants

\section{Postal Delivery System:}

Rural - to individual boxes at curb

Townhouses - gang box located off parking bay

Apartments - gang box one/12 d.u.; located inside building entry

\section{Telephone/TV Cable System and Characteristics:}

\section{No TV cable}

Telephone - buried cable by C\&P

$$
\text { - toll call to Maryland and Washington, D.C. }
$$

\section{Fire/Police Alarm System:}

Alarm by telephone from residential units Alarm system at commercial building 


\section{Building Data for Energy Profile \\ Garden Apartment Example}

This is an example of the data gathered on and

structures for development of the energy profile.

(See Appendix for other bulding types.)
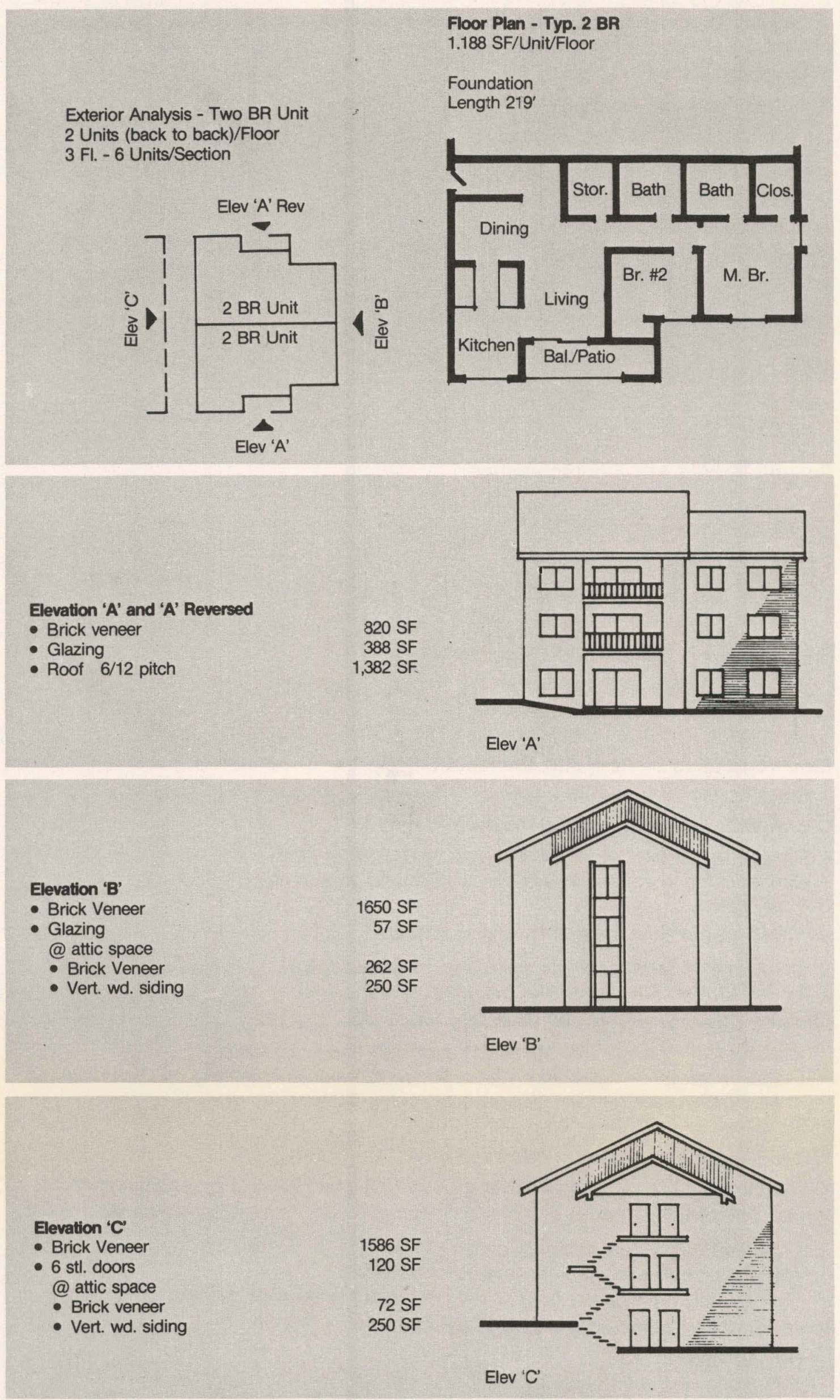

Figure 22. Building Data for Energy Profile 


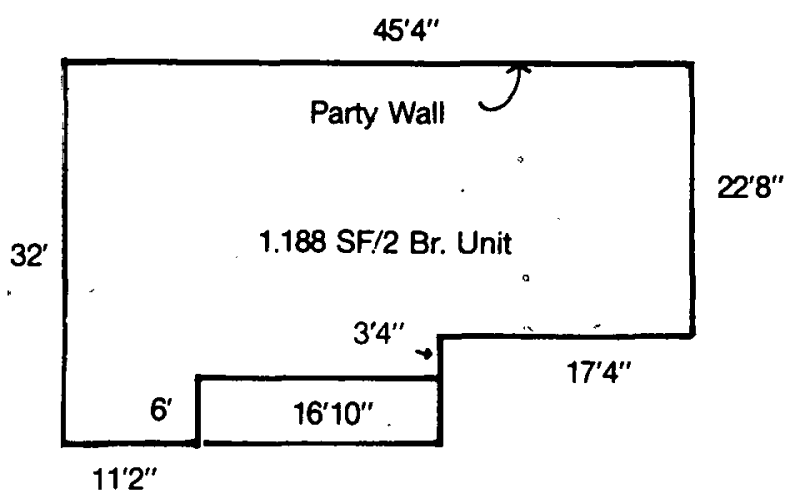

\section{- Unit Type \& Charactertstics}

Garden Apartments, 3 floors/bldg. section, 2 units/fl. (back to back). Ea. bldg. section separated by

covered connecting link \& stairs. Party wall - double $2 \times 3$ wd. studs @ 16" O.C. 1" air space (2) 31/2"

batt insul., $1 / 2$ " drywall ea. side.

\section{- Foundation}

Slab on grade - perimeter length $219^{\prime}$

Materials - $8^{\prime \prime}$ conc. block $-2.5^{\prime}$ deep - $100 \%$ below grade

4" conc. block plus 4 " brick - 8" deep - $100 \%$ above grade

\section{- Floors (2 units/fil.)}

1st Floor 2376 SF - slab on grade (4")

2nd Floor 2376 SF - 14" wd. truss @ 3/4" plywd., 31/2 batt - 5/8" drywl. ceil.

3rd Floor 2376 SF - (same as above) unheated attic above.

\section{- Exterlor Walls (ceiling ht. 8'0')}

Materials

A. Brick veneer

$4^{\prime \prime}$ face brick

$4^{\prime \prime}$ conc. block

$2 \times 4$ studs, 16" OC. @ 1" air space

$31 / 2$ " batt insulation

$1 / 2$ " sheet rock

B. Glazing

Insulated glass $w /$ alum. frames

C: Door (steel insulated)

D. Brick@ attic (4" brick/4" block)

E. Wd. siding @ attic (wd. siding on $2 \times 4$ studs)

\section{- Roof and Ceiling}

- Ceiling 2376 SF. @ 6"' R-30 insulation above

Perimeter Areas - Prototype/Bldg. Section 6 Units/2 Fls, 3 Fioors

\begin{tabular}{|c|c|c|c|c|}
\hline & & Square & & \\
\hline Material & Wall 'A' & Wall 'A' Rev. & Wall 'B' & Wall 'C' \\
\hline Brick Veneer & 820 & 820 & 1650 & 1586 \\
\hline Glazing & 388 & 388 & 57 & - \\
\hline Brick@ attic & 一 & 一 & 262 & 72 \\
\hline Wd. siding@ attic & - & 一 & 250 & 250 \\
\hline Doors & - & - & - & (6) 120 \\
\hline Roof $6 / 12$ pitch & 1382 & 1382 & - & - \\
\hline Orientation & south & north & east & west \\
\hline & & . &. & shielded \\
\hline
\end{tabular}

- Roof - Pitched truss 6/12 pitch

Materials:

Asphalt shingles

1 layer \#15 roofing felt

3/8" plywood

Trusses - pre-fab @2'0" O.C.

$6^{\prime \prime}$ batt insulation

5/8" sheetrock ceiling

Attic Space:

Unheated, natural ventilation, Ht. 0-16'

\section{- HVAC}

1 heat pump/unit, 6/bldg. section Approx. 9,504 cu. ft./unit

(electric)

\section{- Fixtures \& Appliances}

\begin{tabular}{|l|cccccccccccc|}
\hline & Sinks & Lav. & $\begin{array}{c}\text { Tub } \\
\text { Shower Heater }\end{array}$ & Ref. & $\begin{array}{c}\text { Dis- } \\
\text { posal }\end{array}$ & $\begin{array}{c}\text { Dish } \\
\text { Wash. }\end{array}$ & Range Wash. & Dryer & Fans & Smoke \\
Detec.
\end{tabular}




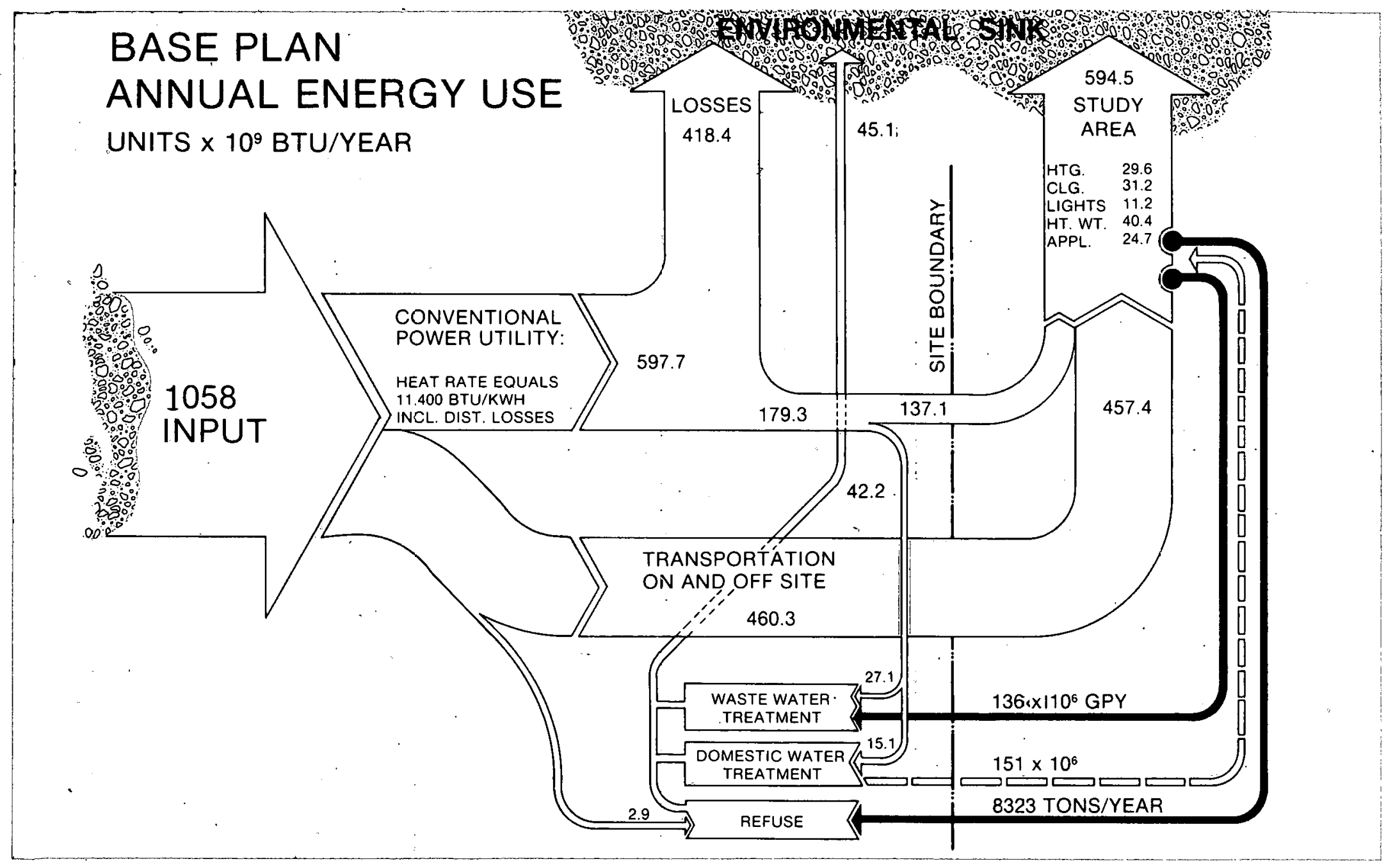

Figure 23 Base Plan - Annual Energy Use

Table 9. Base Plan Energy Use

\begin{tabular}{|c|c|c|}
\hline & Annual Site Energy Use & Total \\
\hline HVAC, Lighting, Appliances, and Hot Water & $137.1 \times 10^{9} \mathrm{Btu} / \mathrm{yr}$ & $21.0 \%$ \\
\hline Transportation: & $96.2 \times 10^{9} \mathrm{Btu} / \mathrm{yr}$ & $15.0 \%$ \\
\hline Off-site & $361.2 \times 10^{9} \mathrm{Btu} / \mathrm{yr}$ & $57.0 \%$ \\
\hline Potable Water Treatment: & $15.1 \times 10^{9} \mathrm{Btu} / \mathrm{yr}$ & $2.0 \%$ \\
\hline Wastewater Treatment: & $27.1 \times 10^{9} \mathrm{Btu} / \mathrm{yr}$. & $4.0 \%$ \\
\hline Refuse Collection and Disposal: & $2.9 \times 10^{9}$ Btu/yr. & $1.0 \%$ \\
\hline Total Base Plan Energy Use: & $639.6 \times 10^{9} \mathrm{Btu} / \mathrm{yr}$. & $100.0 \%$ \\
\hline
\end{tabular}




\section{Engineering Analysis}

The Site Data \& Energy Profiles were used to determine the energy requirements of each residential, recreational, and commercial building type on the base plan.

\section{Space Conditioning}

The energy utilized by the buildings in the Burke Centre study area is of great importance. Though not as great in magnitude as some of the other community energy components such as transportation, it is nevertheless, one of the more complex to estimate.

The Base Plan as investigated was composed of 1624 residential units. They comprise eighty-three percent of the floor space under study with the balance going to recreational and commercial uses. Table 10 illustrates the Base Plan total annual energy use of buildings. The Base Plan energy use total for the study buildings can be split as follows:

\begin{tabular}{lr} 
Heating & $22 \%$ \\
Cooling & $23 \%$ \\
Lighting & $8 \%$ \\
Appliances & $18 \%$ \\
\multicolumn{2}{c}{ \& Equipment } \\
Hot Water
\end{tabular}

Hot Water 29\%

Tables 11 through 14 show a further disaggreation of the energy requirements for the residential, recreational and commercial building types.

Table 15 shows the base plan space conditioning equipment costs.
Table 10. Base Plan Total Energy Use of Buildings in the Burke Center Study Area $\times 10^{9}$ Btu/yr

\begin{tabular}{|c|c|c|c|c|}
\hline & $\begin{array}{c}\text { Residential' } \\
\text { Energy Use } \\
\text { Totals }\end{array}$ & $\begin{array}{c}\text { Recreational2 } \\
\text { Energy Use } \\
\text { Totals }\end{array}$ & $\begin{array}{l}\text { Commercial } \\
\text { Energy Use } \\
\text { Totals }\end{array}$ & $\begin{array}{c}\text { Study Area } \\
\text { Energy Use } \\
\text { Totals }\end{array}$ \\
\hline $\begin{array}{l}\text { Total Floor Area } \\
(\text { Sq. Ft. }) \times 10^{3}\end{array}$ & 2,298 & $\begin{array}{r}81.7 \\
=\quad \\
\end{array}$ & .323 .9 & $2,703.6$ \\
\hline F Heating & 24.1 & 2.8 & 2.7 & 29.6 \\
\hline Cooling : & 21.3 & 3.6 & 6.3 & 31.2 \\
\hline Lighting & 6.2 & 1.8 & 3.2 & 11.2 \\
\hline $\begin{array}{l}\text { Appliances and } \\
\text { Equipment }\end{array}$ & 23.3 & 0.4 & 1.0 & 24.7 \\
\hline Hot Water & 31.5 & 2.8 & 2.1 & 40.4 \\
\hline TOTAL & 110.4 & 11.4 & 15.3 & 137.1 \\
\hline $\begin{array}{l}\text { Energy Cost } \\
\$ 10^{3} / \mathrm{yr} \text {. }\end{array}$ & 1,325 & 107 & 163 & 1,595 \\
\hline $\begin{array}{l}\text { Energy Use Index (EUI) } \\
\text { Btu/sq. ft./yr. }\end{array}$ & 48,042 & 139,935 & 47,237 & 50,710 \\
\hline $\begin{array}{l}\text { 'High Rise Apts. } \\
\text { Garden'Apts. } \\
\text { Cluster Units } \\
\text { Four/Plex Units } \\
\text { Townhouses }\end{array}$ & \multicolumn{2}{|c|}{$\begin{array}{l}\text { 'Bowling Alley } \\
\text { Health \& Racquet Club } \\
\text { Roller Skating Rink } \\
\text { Neighborhood \& Community } \\
\text { Meetings \& Pool Bathhouse }\end{array}$} & \multicolumn{2}{|c|}{$\begin{array}{l}{ }^{3} \text { Dinner Theatre } \\
\text { Office Bldgs. 1, } 2 \& 3 \\
\text { Commercial/Retail Bldgs. } \\
\quad 1,2, \& 3\end{array}$} \\
\hline
\end{tabular}

* Table for E/CPlan not in the report; see Table $18 \mathrm{in}$ appendix.

Table 11. Base Plan Energy Use Per Ave. Residential Unit x $10^{6} \mathrm{Btu} / \mathrm{yr}$

\begin{tabular}{|c|c|c|c|c|c|c|}
\hline & $\begin{array}{c}\text { High } \\
\text { Rise } \\
\text { Apts. } \\
\text { (Parcel 23) }\end{array}$ & $\begin{array}{c}\text { Garden } \\
\text { Apts. } \\
\text {. (Parcel } 22 \text { \& 23) }\end{array}$ & $\begin{array}{c}\text { Cluster } \\
\text { Units } \\
\text { (Parcel 24A \& B) }\end{array}$ & $\begin{array}{c}\text { Four/Plex } \\
\text { (Parcel 12C) }\end{array}$ & $\begin{array}{l}\text { Townhouse } \\
\text { (Parcel 22) }\end{array}$ & $\begin{array}{c}0 \\
\text { Townhouses } \\
\text { (Parcel 12B) }\end{array}$ \\
\hline Heating & 11.3 & 14.7 & 6.9 & 13.1 & 22.2 & 21.4 \\
\hline Cooling & 13.0 & 12.3 & 13.8 & 12.5 & 16.0 & 15.6 \\
\hline Lighting & 4.2 & $\cdot 2.9$ & 2.8 & 3.5 & 6.4 & 6.4 \\
\hline Appliances \& Equipment & 13.5 & 13.1 & 16.6 & 16.6 & 16.6 & 16.6 \\
\hline Hot Water & 19.6 & 19.7 & 25.0 & 24.1 & 29.7 & 30.0 \\
\hline TOTAL & 61.6 & 62.7 & 65.1 & 69.8 . & 90.9 & 90.0 \\
\hline Energy Cost $\$ / y r$. & 757 & 768 & 786 & 834 & 1,037 & 1,028 \\
\hline
\end{tabular}


Table 12. Base Plan Total Energy Use Per Residential Type $\times 10^{9} \mathrm{Btu} / \mathrm{yr}$.

\begin{tabular}{|c|c|c|c|c|c|c|c|}
\hline & $\begin{array}{c}\text { High } \\
\text { Rise } \\
\text { Apts. } \\
\text { (Parcel 23) }\end{array}$ & $\begin{array}{c}\text { Garden } \\
\text { Apts. } \\
\text { (Parcel 22 \& 23) }\end{array}$ & $\begin{array}{c}\text { Cluster } \\
\text { Units } \\
\text { (Parcel 24A \& B) }\end{array}$ & $\begin{array}{c}\text { Four/ } \\
\text { Plex } \\
\text { (Parcel 12C) }\end{array}$ & $\begin{array}{l}\text { Townhouse } \\
\text { (Parcel 22) }\end{array}$ & $\begin{array}{l}\text { Townhouse } \\
\text { (Parcel 12B) }\end{array}$ & $\begin{array}{c}\text { Residential } \\
\text { Totals }\end{array}$ \\
\hline No. Units & 336 & 852 & 48 & 116 & 172 & 100 & 1,624 \\
\hline $\begin{array}{l}\text { Total Flr. Area } \\
\text { (Sq. Ft.) } \times 10^{z}\end{array}$ & 524 & 918 & 50 & 168 & 403 & 235 & 2,298 \\
\hline Heating & 3.90 & 12.52 & .33 & 1.52 & 3.82 & 2.14 & 24.13 \\
\hline Cooling & 4.37 & 10.48 & .66 & 1.45 & 2.75 & 1.56 & 21.27 \\
\hline Lighting & 1.41 & 2.47 & .13 & .41 & 1.10 & .64 & 6.16 \\
\hline $\begin{array}{l}\text { Appliances \& } \\
\text { Equipment }\end{array}$ & 4.54 & 11.50 & .80 & 1.93 & 2.86 & 1.66 & 23.29 \\
\hline TOTAL & 20.82 & 53.77 & 3.12 & 8.11 & 15.63 & 9.00 & 110.45 \\
\hline $\begin{array}{l}\text { Energy Cost } \\
\$ 10^{3} / \mathrm{yr}\end{array}$ & 254.4 & 654.5 & 37.7 & 96.7 & 178.4 & 102.8 & $1,324.5$ \\
\hline
\end{tabular}

Table 13. Base Plan Total Energy Per Commercial/Recreational Type $\times 10^{6} \mathrm{Btu} / \mathrm{Yr}^{1}{ }^{1}$

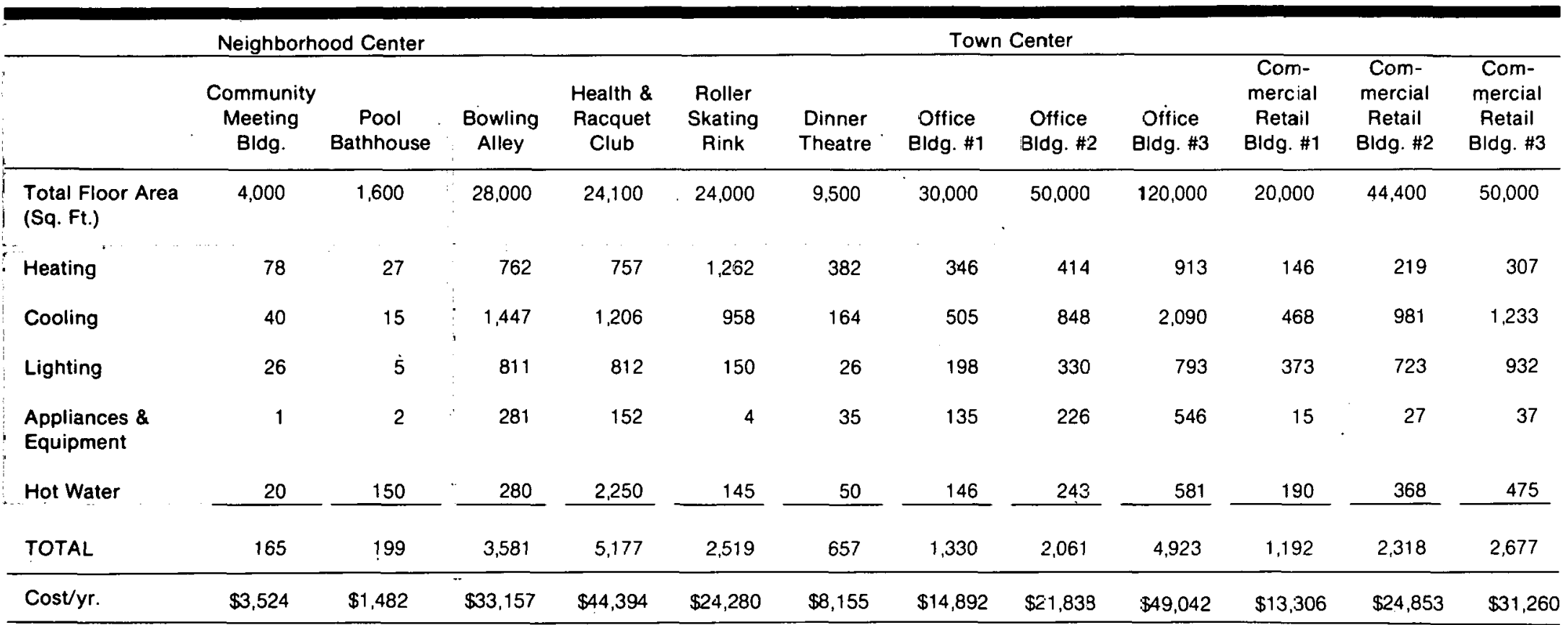

'All have air-to-air heat pumps except Office \#1, 2, 3 which have electric resistance heat

$\begin{array}{lll}\text { Heat Pump C.O.P.: } & \text { Heating } & 1.8 \\ & \text { Cooling } & 1.7 \\ & & \\ \text { Distribution Efficiency: } & 0.95 \\ \text { Electric Resistance: } & 0.95\end{array}$

Similar table for E/C plan not in report. See Table

20 in appendix. 


\section{Water Energy Use}

The base plan water energy use for Burke Centre has been developed for those energy expenditures for:

- Potable water treatment and distribution, and

- Primary, secondary, and tertiary wastewater treatment.

Currently, these water services are handled via a county wide system of water and wastewater treatment systems. Due to these off-site water handling practices, water related energy uses have been developed along these lines.

The basic method which was employed for the estimate of water energy use is as follows:

(1) The water use per residential dwelling unit (apartments, high-rise, townhouse, 4-plex) was determined based on a national average of 2.5 people/ D.U. having a per capita water use of 85 gallons per day.

(2) The water use per commercial/retail/ recreational building was based on data obtained from Reference 3.

(3) Domestic hot water requirements were predicted using coefficients from Reference 3.

(4) Based on the projected annual water consumption for each of these building types, water related energy expenditures were developed. The premises utilized for this analysis were:

(a) $100 \mathrm{Btu} /$ gallons of water - potable water treatment and distribution (Ref. 2, 3)

(b) $200 \mathrm{Btu} /$ gallons of wastewater primary, secondary, and tertiary wastewater treatment (assumed to be $90 \%$ of potable water use flow) (Ref. 2, 3)

(5) The total water use and associated energy expenditures have been presented for each parcel and building type in Table 16.

The associated water energy use for storm drainage and runoff has been considered to be zero since the sewer systems utilized will be a segregated wastewater-storm drainage system. Based on this, there will be no operational energy expenditures for storm water retention, distribution, or treatment.

\begin{tabular}{|c|c|c|c|c|c|c|}
\hline Parcel & $12 B$ & $12 \mathrm{C}$ & $\begin{array}{l}\text { Neighborhood } \\
\text { Center and } \\
\text { Town Center }\end{array}$ & 22 & 23 & $24 A \& B$ \\
\hline $\begin{array}{l}\text { Total Flr. Area } \\
(\text { Sq. Fl. }) \times 10^{3}\end{array}$ & 235 & 168 & 405.6 & 675 & 1.170 & 50.0 \\
\hline Heating & 2.14 & 1.52 & 5.61 & 7.52 & 12.72 & 0.33 \\
\hline Cooling & 1.56 & 1.45 & 9.55 & 5.85 & 11.75 & 0.66 \\
\hline Lighting & 0.64 & 0.41 & 5.18 & . 1.83 & 3.15 & 0.13 \\
\hline $\begin{array}{l}\text { Appliances \& } \\
\text { Equipment }\end{array}$ & 1.66 & 1.93 & 1.46 & 6.26 & 12.63 & 0.80 \\
\hline Hot Water & 3.00 & 2.80 & 4.90 & 10.10 & 18.40 & 1.20 \\
\hline TOTAL & 9.00 & 8.11 & 26.70 & 31.56 & 58.65 & 3.12 \\
\hline
\end{tabular}

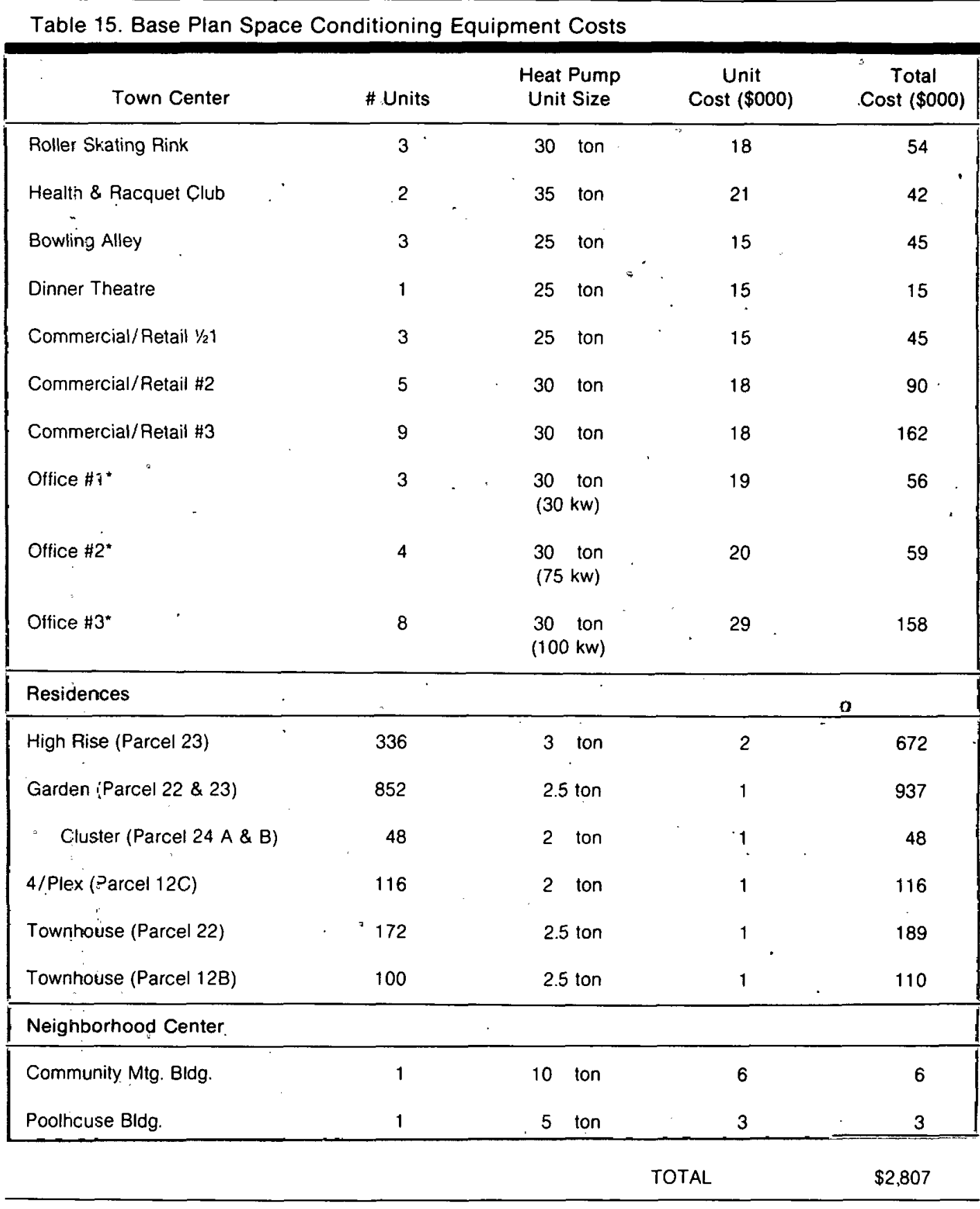

"Contain electric resistance forced air heat and unitary $A / C$ units.

See Table 22 in appendix for E/Cplan. 
Table 16. Burke Centre Base Plan Annual Water, Hot Water, and Wastewater Demand and Energy Use

\begin{tabular}{|c|c|c|c|c|c|}
\hline \multirow[b]{3}{*}{ Parcel } & \multicolumn{3}{|c|}{ Water } & \multicolumn{2}{|c|}{ Wastewater } \\
\hline & \multicolumn{3}{|c|}{ Trea:ment/Dist } & \multirow{2}{*}{$\begin{array}{c}\text { Load } \\
\left(10^{6} \mathrm{gal} / \mathrm{yr} .\right)\end{array}$} & \multirow{2}{*}{$\begin{array}{l}\text { Treatment } \\
\text { Energy Use } \\
\left(10^{9} \mathrm{Btu} / \mathrm{yr} \text {. }\right.\end{array}$} \\
\hline & $\begin{array}{c}\text { Demand } \\
\left(10^{6} \mathrm{gal} / \mathrm{yr} \text {. }\right)\end{array}$ & $\begin{array}{l}\text { Energy Use } \\
\left(10^{\circ} \text { Btu/yr. }\right)\end{array}$ & $\begin{array}{l}\text { H-W Energy } \\
\left(10^{8} \text { Btu/yr. }\right)\end{array}$ & & \\
\hline \multicolumn{6}{|l|}{ Residential } \\
\hline High Rise (Parcel 23). & 23 & 2.3 & 6.6 & 20.7 & 4.1 \\
\hline Garden (Parcel 23) & 42 & 4.2 & 11.8 & 37.8 & 7.6 \\
\hline Garden (Parcel 22) & 18 & 1.8 & 5.0 & 16.2 & 3.2 \\
\hline Cluster (Parcel 24 A \& B) & 4 & .4 & 1.2 & 3.6 & 0.7 \\
\hline 4/Plex (Parcel 12C) & 10 & 1.0 & 2.8 & 9.0 & 1.8 \\
\hline Townhouse (Parcel 22) & 18 & 1.8 & 5.1 & 16.2 & 3.2 \\
\hline Townhouse (Parcel 12B) & 11 & 1.1 & 3.0 & 9.9 & 2.0 \\
\hline Residential Total & 126 & 12.6 & 35.5 & 113.4 & 22.6 \\
\hline \multicolumn{6}{|l|}{ Recreational } \\
\hline Bowling Alley & 1.2 & 0.1 & 0.3 & 1.1 & 0.2 \\
\hline Health \& Racquet Club & 3.0 & 0.3 & 2.3 & 2.7 & 0.5 \\
\hline Roller Skating Rink & 1.4 & 0.1 & 0.1 & 1.3 & 0.3 \\
\hline Neighborhood Center & 0.4 & 0.1 & 0.1 & 0.4 & 0.1 \\
\hline Recreational Total & $6.0^{\circ}$ & 0.6 & 2.8 & 5.5 & 1.1 \\
\hline \multicolumn{6}{|l|}{ Commercial. } \\
\hline Dinner Theatre & 0.2 & 0.1 & 0.1 & 0.2 & 0.1 \\
\hline Office Buildings & 12.0 & 1.2 & 1.0 & 10.8 & 2.2 \\
\hline Commercial: Retail & 6.4 & 0.6 & 1.0 & 5.8 & 1.2 \\
\hline SITE TOTALS & 150.6 & 15.1 & 40.4 & 135.7 & 27.1 \\
\hline
\end{tabular}

\section{Solid Waste Energy Use}

The base plan solid waste energy use for Burke Centre has been developed for that energy required to collect and transport solid waste to a disposal site 10 miles from Burke Centre. In addition to the total solid waste generated from the community will be assumed to be:

- Residential - 7.2 lbs. per day per capita (Ref. 17, 38)

- Commercial - 2.0 lbs. per day per 1000 sq. ft. floor area (Ref. 17, 38)

Table 17. Annual Baseline Solid Waste Collection and Transportation Energy Use

\begin{tabular}{|c|c|c|c|c|}
\hline & $\begin{array}{l}\text { Solid Waste } \\
\text { Tons Per Year }\end{array}$ & $\begin{array}{l}\text { Load Trips } \\
\text { Per Year }\end{array}$ & $\begin{array}{c}\text { Diesel Fuel } \\
\text { Gallons Per } \\
\text { Year }\end{array}$ & $\begin{array}{c}\text { Annual Energy } \\
\text { Use ( } 10^{\circ} \mathrm{Btu} \\
\text { Per Year) }\end{array}$ \\
\hline Residential & $8,147.0$ & $3,260.0$ & 20,375 & 2.89 \\
\hline $\begin{array}{l}\text { Commercial/Otfice/ } \\
\text { Retail/Recreational }\end{array}$ & 176.4 & 41.5 & 259 & 0.04 \\
\hline Total & $8,323.4$ & $3,301.5$ & 20,634 & 2.93 \\
\hline
\end{tabular}

\section{Transportation Energy Use}

Transportation is a major energy consumer in any urban or suburban area. It is, however, difficult in analyzing a development such as Burke Centre to define the most relevant figure to use for a transportation energy use analysis. Several possible measures of transportation energy use are possible:

(1) The total energy used by all traffic generated by the Burke Centre development. This includes a substantial amount of energy that is consumed outside of the development area by vehicles traveling to or from Burke Centre.

(2) The total amount of energy consumed by transportation vehicles within the land parcels which form the energy study area. The disadvantage of this measure is that a very small amount of energy is used within these areas. There is little that can be done to change the amount of energy used within the parcels because the low traffic levels in these areas give the transportation system a very high efficiency.

(3) The total amount of energy consumed in the entire Burke Centre complex for transportation. The difficulty of this measure is that it would require detailed study of portions of Burke Centre that are not under consideration in the present Burke Centre analysis.

Assuming that the average residential use packer truck can carry $20 \mathrm{cu}$. yards of solid waste per load and that commercial use packer trucks may carry up to $34 \mathrm{cu}$. yards per load, the annual energy expenditure for solid waste collection and transportation at an estimated fuel use of 4 miles/gallon has been estimated and is presented in Table 17.

ed on these problems a multiple approach has been taken. For the base case analysis, two basic transportation measures have been used: the total energy consumed by all trips terminating or originating in the study parcels and the energy used within the entire Burke Centre area by these trips. This two-tiered approach allows the effects of any mass transportation/carpool approaches to be determinded (since these measures affect the travel to and from the study area) as well as the effect of road network or land use changes within Burke Centre (these changes affect the efficiency of travel inside Burke Centre). 


\section{Travel to and from Burke Centre}

In determining the energy used by vehicles traveling to and from Burke Centre, three factors must be determined:

(a) How many trips end or begin in the study area (trip generation rates)

(b) The distance of an average trip

(c) The fuel consumption of the vehicies making each trip.

a. Determination of Trip Generation Rates. Trip generation rates vary extensively based on the type of land use. Very intensive land uses, such as shopping centers or other types of commercial development, have much higher trip generation rates than residential land uses. Because of this, it is necessary to consider each land use type independently and sum the total trips from each area to obtain the total trip generation. Trip generation rates have been studied extensively in regional transportation studies throughout the United States. The results of these studies have been compiled in Trip Generation Intensity Factors (Ref. 7) which was used to determine trip generation rates for Burke Centre. National average trip generation rates were used for the analysis.

b. Determination of Average Trip Lengths. Trip length is one of the most difficult quantities to estimate because it is very strongly affected by the transportation and land use plan of the region and local attitudes towards driving. For greatest accuracy, data collected by the Washington Area Council of Governments (Ref. 24) have been used to estimate average trip lengths for the study area. This information is shown in Table 18. c. Determination of Average Fuel Economy. An average fuel economy of 14.6 miles per gallon (.0685 gallons per mile) has been assumed for this analysis. This figure is a Hittman Associates' estimate which is based on Department of Transportation Statistics and Environmental Protection Agency mileage data. It represents the projected average fuel economy for the 1980 calendar year.

d. Baseline Fuel Use. The analysis of fuel use for all trips originating or terminating in the study area is shown in Tables 19 and 20 . These tables indicate the trips generated in each of the parcels, the average length of each trip, the total vehicle miles traveled (VMT) and the energy use for these trips. The total energy use for all trips is $457.4 \times 10^{9}$. Btu/yr. In converting gallons of gasoline to Btu we have assumed a heat content of gasoline of 125,000 Btu/gal. (Ref. 22).

Table 18. Average Trip Lengths for the Burke Centre Area

\begin{tabular}{|lc|}
\hline Type of Trip & $\begin{array}{c}\text { Average Trip Length } \\
\text { (Miles) }\end{array}$ \\
Residential & 7.1 \\
Office & 8.9 \\
Shop and Cultural & 5.8 \\
Parks \& Recreation, & 12.4 \\
\hline
\end{tabular}

SOURCE: Washington Council of Governments, "Fuel Restrictions and Travel Implications for the National Capital Region," Information Report $\# 60,1973$.

\section{Travel Within Burke Centre}

In order to determine the travel within the Burke Centre development, it is necessary to know the distances from each point of origin to the boundary of the Burke Centre development. The method that was used to determine these distances is as follows:

(a) For each parcel, the distances from the various parking areas to the exit point from the parcel were measured off of the site plan maps. These distances were averaged to determine the average distance of a trip within each parcel. This task was relatively straightforward for the residential areas in Parcels 22, 12 and 24 since there is only one exit to the arterial roadway network. For the town center parcels, there are multiple exits to the arterial road network. In this case the distances to several of the outlets were determined and depending upon the assumed destination of each trip (see below), the most appropriate route out of the parcel was used to determine the distance.

(b) It was assumed that all of the trips originating in the Burke Centre study area leave the development at one of three locations: the intersection of Burke Centre Parkway and Route 123 ( $30 \%$ of all trips), the intersection of Roberts Parkway and Guinea Road ( $30 \%$ of all trips), or the intersection or Burke Centre Parkway and Burke Lake Road ( $40 \%$ of all trips). The distances from each parcel to these intersections were determined and added to the already determined average distances within each parcel to obtain the average distance from each parcel to the point of exit from Burke Centre.

Table 19. Total Transportation Energy Use - Residential

\begin{tabular}{|c|c|c|c|c|c|c|c|c|}
\hline & Housing Units & Parcel & $\begin{array}{l}\text { No. } \\
\text { Units }\end{array}$ & $\begin{array}{l}\text { Trips } \\
\text { Per } \\
\text { Unit' }\end{array}$ & $\begin{array}{l}\text { Miles } \\
\text { Per } \\
\text { Trip }\end{array}$ & $\begin{array}{l}\text { Total } \\
\text { VMT }\end{array}$ & $\begin{array}{l}\text { Fuel Used } \\
\text { (Gals/Day) }\end{array}$ & $\begin{array}{c}\text { Energy Use } \\
\text { (Btu/yr.) }\end{array}$ \\
\hline : & Townhouses & $12 B$ & 100 & $\Rightarrow 6.7$ & 7.1 & 4,757 & 326 & $14.87 \times 10^{9}$ \\
\hline & Fourplex & $12 \mathrm{C}$ & 116 & 6.7 & 7.1 & 5,518 & 378 & $17.25 \times 10^{9}$ \\
\hline & Multi-Family Cluster & $24 A \& B$ & 48 & 6.7 & 7.1 & 2,283 & 156 & $.7 .12 \times 10^{9}$ \\
\hline & Townhouses & 22 & 172 & 6.7 & 7.1 & 8,182 & 560 & $25.55 \times 10^{9}$ \\
\hline & Garden Apartments & 22 & 252 & 6.7 & 7.1 & 11,988 & $821^{\circ}$ & $37.46 \times 10^{9}$ \\
\hline & Garden Apartments & 23 & 600 & 6.7 & 7.1 & 28,542 & 1,955 & $89.20 \times 10^{9}$ \\
\hline & High-Rise Apartments & 23 & 336 & 6.7 & 7.1 & 15,984 & 1,095 & $49.96 \times 10^{9}$ \\
\hline & Total & & 1,624 & & & 77,254 & 5,292 & $241.45 \times 10^{9}$ \\
\hline
\end{tabular}

Total Trips $=10,874$ 
To calculate the on-site vehicle miles traveled the number of trips from each parcel was multiplied by the average distance to the Burke Centre boundary to obtain the on-site VMT from trips originating or terminating at each parcel. Both the total onsite VMT and the collector road VMT (the vehicle miles traveled within each parcel) have been calculated. Total on-site energy use has been calculated using the 14.6 mile per gallon figure mentioned previously. The results of the base plan, on-site, energy analysis are shown in Table 21. Because of the nature of the transportation network. Parcels 12 and 24 were considered a single unit as were Parcels 21 and 23. In the town center region (Parcels 21 and 23) the two adjoining parcels were also considered a single unit although the analysis was broken into commercial and residential based transportation. The analysis shows that a total of $96.16 \times 10^{9}$ Btu are used for transportation per year inside the boundaries of Burke Centre for trips originating or terminating in the seven parcels studied. This is 21 percent of the total for on and off site transportation energy use.

Table 20. Total Transportation Energy Use - Commercial

\begin{tabular}{|c|c|c|c|c|c|c|c|}
\hline Land Use Type & $\begin{array}{l}\text { Area } \\
\text { (sq. ft.) }\end{array}$ & $\begin{array}{c}\text { Trips' } \\
\text { per } 1,000 \\
\text { (sq. ft.) }\end{array}$ & $\begin{array}{l}\text { Average }^{2} \\
\text { Trip } \\
\text { Length }\end{array}$ & $\begin{array}{l}\text { Total } \\
\text { Trips }\end{array}$ & $\begin{array}{l}\text { total } \\
\text { VMT }\end{array}$ & $\begin{array}{c}\text { Fuel } \\
\text { Used } \\
\text { (gal/day) }\end{array}$ & $\begin{array}{c}\text { Energy } \\
\text { Used } \\
\text { (Btu/yr.) }\end{array}$ \\
\hline $\begin{array}{l}\text { Shopping Area (include movie } \\
\& \text { dinner theater) }\end{array}$ & 123,000 & 64.4 & 5.8 & 7,921 & 45,900 & 3,140 & $143.26 \times 10^{9}$ \\
\hline Bowling Lanes & 28,000 & 6.8 & 12.4 & 190 & 2,400 & 160 & $7.30 \times 10^{9}$ \\
\hline Racket Club & $\begin{array}{l}75,00 \\
\text { (includes tennis } \\
\text { courts) }\end{array}$ & 1.4 & 12.4 & 105 & 1,300 & 90 & $4.11 \times 10^{9}$ \\
\hline Roller Rink & 24,000 & .6 & 12.4 & $14^{\circ}$ & 200 & 14 & $.64 \times 10^{9}$ \\
\hline Offices & 200,000 & 10.9 & 8.9 & 2,180 & $19, k 402$ & 1,329 & $60.64 \times 10^{9}$ \\
\hline Total & 450,000 & $\begin{array}{l}23.1 \\
\text { (avg.) }\end{array}$ & $\begin{array}{c}6.65 \\
\text { (weighted } \\
\text { average) }\end{array}$ & 10,410 & 69,202 & 4,733 & $215.94 \times 10^{9}$ \\
\hline
\end{tabular}

'Arizona Department of Transportation, Trip Generation Intensity Factors, Published by the U.S. Department of Transportation, 1976.

2Washington Council of Governments, "Fuel Restrictions and Travel Implications for the National Capital Region,"Information Report \#60, 1973.

Table 21. Transportation Energy Analysis - Base Plan

\begin{tabular}{|c|c|c|c|c|c|c|c|c|c|c|c|c|c|c|c|}
\hline & & Distance & Distance & & & & & Collecto & On-Site & & Collecto & or Fuel Use & & On-Sit & e Fuel Use \\
\hline Parcel & $\begin{array}{c}\text { Exit } \\
\text { Point }\end{array}$ & $\begin{array}{c}\text { to } \\
\text { Artery }\end{array}$ & $\begin{array}{c}\text { on } \\
\text { Artery }\end{array}$ & Total & $\begin{array}{l}\text { No. } \\
\text { Units }\end{array}$ & $\begin{array}{l}\text { Trips/ } \\
\text { Units }\end{array}$ & $\begin{array}{l}\text { Total } \\
\text { Trips }\end{array}$ & $\begin{array}{l}\text { Miles/ } \\
\text { Trip }\end{array}$ & $\begin{array}{l}\text { Miles/ } \\
\text { Trip }\end{array}$ & $\begin{array}{l}\text { Collector } \\
\text { VMT }\end{array}$ & Gal/Day & Btu/Yr. & $\begin{array}{c}\text { On-Site } \\
\text { VMT }\end{array}$ & Gal/Day & $\mathrm{Btu} / \mathrm{Yr}$ \\
\hline : & $\begin{array}{r}8 \\
9 \\
9 \\
10\end{array}$ & $\begin{array}{l}1,060 \\
1,060 \\
1,060\end{array}$ & $\begin{array}{l}5,890 \\
5,760 \\
9,570\end{array}$ & $\begin{array}{r}6,950 \\
.6,820 \\
10,630\end{array}$ & 423 & 6.7 & 2,834 & .20 & 1.59 & 567 & 38.8 & $1.77 \times 10^{9}$ & 4,506 & 308.7 & $14.08 \times 10^{9}$ \\
\hline $12 / 24$ & $\begin{array}{r}8 \\
9 \\
10\end{array}$ & $\begin{array}{l}1,940 \\
1,940 \\
1,940^{\circ}\end{array}$ & $\begin{array}{r}2,850 \\
8,800 \\
12,610\end{array}$ & $\begin{array}{r}4,790 \\
10,740 \\
14,550\end{array}$ & 264 & 6.7 & 1,769 & .37 & 1.98 & 655 & 44.9 & $2.05 \times 10^{9}$ & 3.503 & 240.0 & $10.95 \times 10^{9}$ \\
\hline $\begin{array}{l}21 / 23 \\
\text { Residential }\end{array}$ & $\begin{array}{r}8 \\
9 \\
10\end{array}$ & $\begin{array}{l}1,120 \\
1,110 \\
2,140\end{array}$ & $\begin{array}{l}9,540 \\
2,110 \\
5,480\end{array}$ & $\begin{array}{r}10,660 \\
3,220 \\
7,620\end{array}$ & 936 & 6.7 & 6,271 & .29 & 1.37 & 1,819 & 124.6 & $5.68 \times 10^{9}$ & 8,591 & 588.5 & $26.85 \times 10^{9}$ \\
\hline $\begin{array}{l}21 / 23 \\
\text { Commercial }\end{array}$ & $\begin{array}{r}8 \\
9 \\
10\end{array}$ & $\begin{array}{r}940 \\
1,310 \\
1,400\end{array}$ & $\begin{array}{r}9,120 \\
2,720 \\
600\end{array}$ & $\begin{array}{r}10,060 \\
4,030 \\
7,400\end{array}$ & & & 10,410 & .23 & 1.36 & 2,394 & 164.0 & $7.48 \times 10^{9}$ & 14,168 & 970.5 & $44.28 \times 10^{9}$ \\
\hline Total & & & & & & & 21,284 & & & 5,435 & 372.3 & $16.99 \times 10^{9}$ & 30,768 & $2,107.6$ & $96.16 \times 10^{9}$ \\
\hline
\end{tabular}

"Key to exit points: $8=$ Burke Centre Parkway and Rt. 123

$9=$ Roberts Parkway and Guinea Road

$10=$ Burke Centre Parkway and Burke Lake Road 


\section{Energy Options \& Screening Methodology}

\section{Development of a Detailed Energy Conserving Options List}

Based on the detailed analysis of the study area, a generic options listing was developed and categorized by systems, site, and operations. Approximately 300 option combinations were defined and developed for five distinct levels of potential application:

A. Community Level - The entire Burke Centre Site consists of 1,500 acres and proposed 5,000 or so dwelling units as well as the planned community, recreational, commercial and industrial uses. Emphasis here was placed not only on options within the community, but also the effect such options might have on larger regional options or alternatives.

B. Neighborhood Level - The Study Area - The proposed study area of approximately 210 acres including 1624 dwelling units, a 400,000 square feet town center, and appropriate recreational and community uses.

C. Sub-Neighborhood Level - Parcels or portions of parcels which were isolated for study purposes either by the nature of their land form or other physiographic features, by zoning implications, by ownership, or by a particular residential unit type. The town center site would also be in this category.

D. Building Grouping Level - A grouping of commercial or residential unit types such as a highrise, garden apartment complex or quadraplex (4-plex).

E. Unit Level - This level dealt with options as they relate to a specific and individual residential or building type such as a single apartment unit, or a specified commercial use.

The detailed energy conserving options list for the five distinct levels of potential application can be found in the Appendix Document. The levels of potential applicability were determined by group consensus representing the points-of-view of the builder-developer, energy engineer, architect and land use planner.

\section{Application of the Qualitative Screening Methodology}

In this step the study team applied a screening process to establish a base list having an optimistic chance of success. In order to simplify the handling of the large list of energy conservation options, a rough pass/fail screening was conducted. An interdisciplinary group consisting of the study team's staff members was assembled to provide the perspective of the builder-developer, architect, engineer, planner, buyer/tenant, utility, regulatory/ code inspector, and financier. This group reviewed each option and its potential applicability on essentially a pass/fail basis. This decreased the list to more manageable proportions.

\section{(1) Energy Conservation Potential}

(2) Technological State-of-the Art

(3) Economic Feasibility

(4) Institutional Marketing and Other Considerations

Detailed descriptions of these criteria can be found in the Appendix Document.

The list of options in Table 22 represents those which survived the screening process at one level or another. They are presented in the various categories of community development in which they were incorporated into the energy conserving plan. The list of options in Table 23 represents those which failed the screening process.

Due to the limits of this study and the testing methodologies available not every option was tested. Many of the site options incorporated into the plan are recognized climate modifiers and were included as a matter of course. Many of the specific building modifications, operations and systems options suggested in this list were not tested as part of this study. Our testing focused primarily on community wide and neighborhood wide conservation and the use of water source heat pumps, transportation, community layout (orientation), water, sewer and solid waste disposal as a result of screening the original options list. 
The options which are described are divided into three categories as follows:

Options included in the E/C plan that were tested for specific conservation value.

$\frown$ Options included in the E/C plan with inherent or recognized energy conserving values, that were not tested as part of this study.

(R)

Options recommended for consideration by developer/builder, resident, tenant, or local government which relate to certain operations, services, systems or building techniques which could not be quantified as part of this case study; or, the options were already included in the baseplan.
Table 22

Energy Conservation Options Surviving the Screening Process

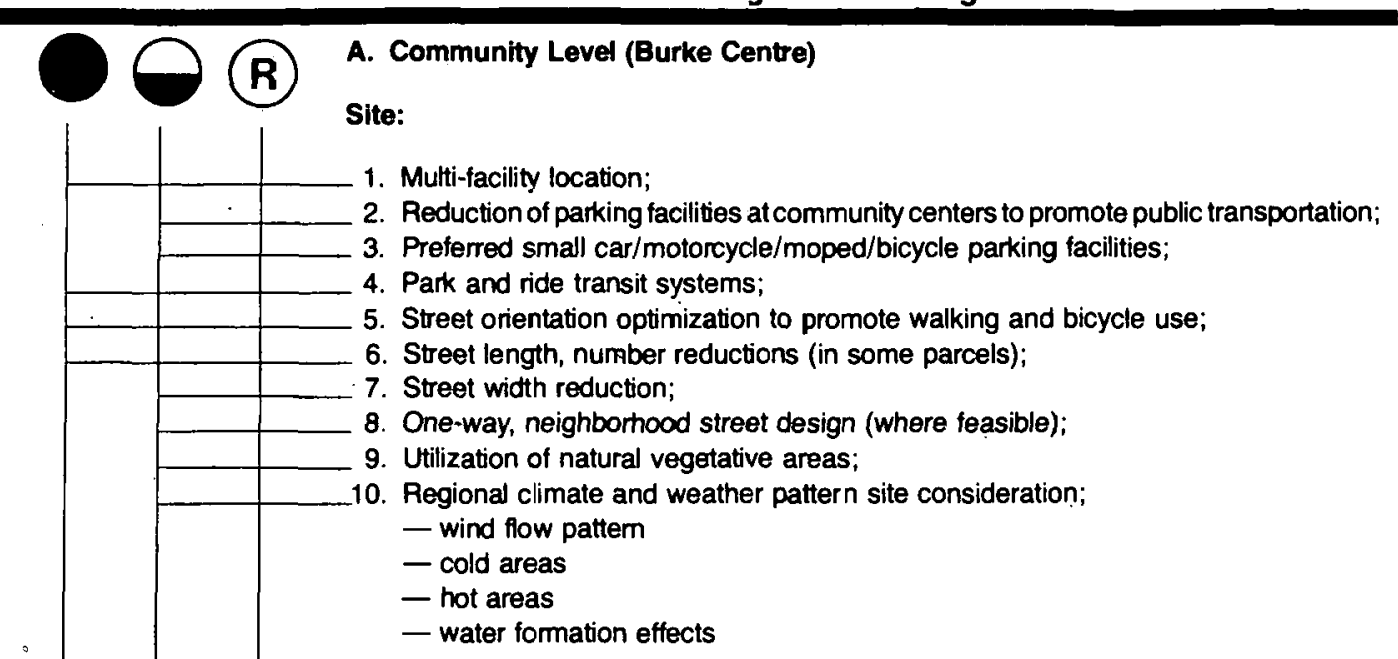

Systems \& Operations

11. Mail senvice optimization

- pneumatic mail service

- electric vehicle mail transportation

- neighborhood box pickup

- elimination of special delivery operations

- institution of private competitive mail service operations 12. Telephone shopping

13. Encouragement of bicycle/moped/walking transit

14. Promote jitney (part-time taxi) facilities. Provide or encourage transit or para-transit service within and outside of community.

15. High efficiency street, biilding and highway lighting systems;

16. Standardized receptacle refuse collection systems.

\section{B. Neighborhood Level (Study Area)}

Site:

17. Building arrangement and orientation optimization on site;

- solar orientation maximized

- avoidance of valley and pocket areas

- utilization of subterranean or quasi-sublerranean structures - clustering

18. Envelope zoning (sunshine easement);

19. Windbreak/wind intensifier natural site utilization. Summer/winter climate optimization. Landscape element utilization - landforms, berming, vegetation, water bodies; 20. Natural drainage pattern utilization for storm water runoff drainage and retention; 21. Street size reduction to minimize vehicular speed.

\section{Systems \& Operations}

22. Neighborhood mail service optimization (refer to community level);

23. Neighborhood recreational facility locations. Given in base plan

24. Institute vanpool, carpool transit systems.

\section{Sub-Neighborhood Level (Individual Parcel)} Site:

25. Building clustering (town center tested);

26. Utilization of berming for structures (town center and neighborhood center parking lots);

27. Minimize site disturbance:

28. Building height and shape changes to optimize wind streamlining:

29. Building rowhouse arrangement;

30. Location of structures close to leeward side of water bodies (where possible);

31. Envelope zoning (sunshine easement, wind easement);

32. Vegetative arrangement to optimize heating, cooling, wind break, wind intensifie effects;

33. Use of minimum maintenance vegetative materials:

34. Low reflectivity material uttilization on parking lots, walkways, and surrounding building areas. 


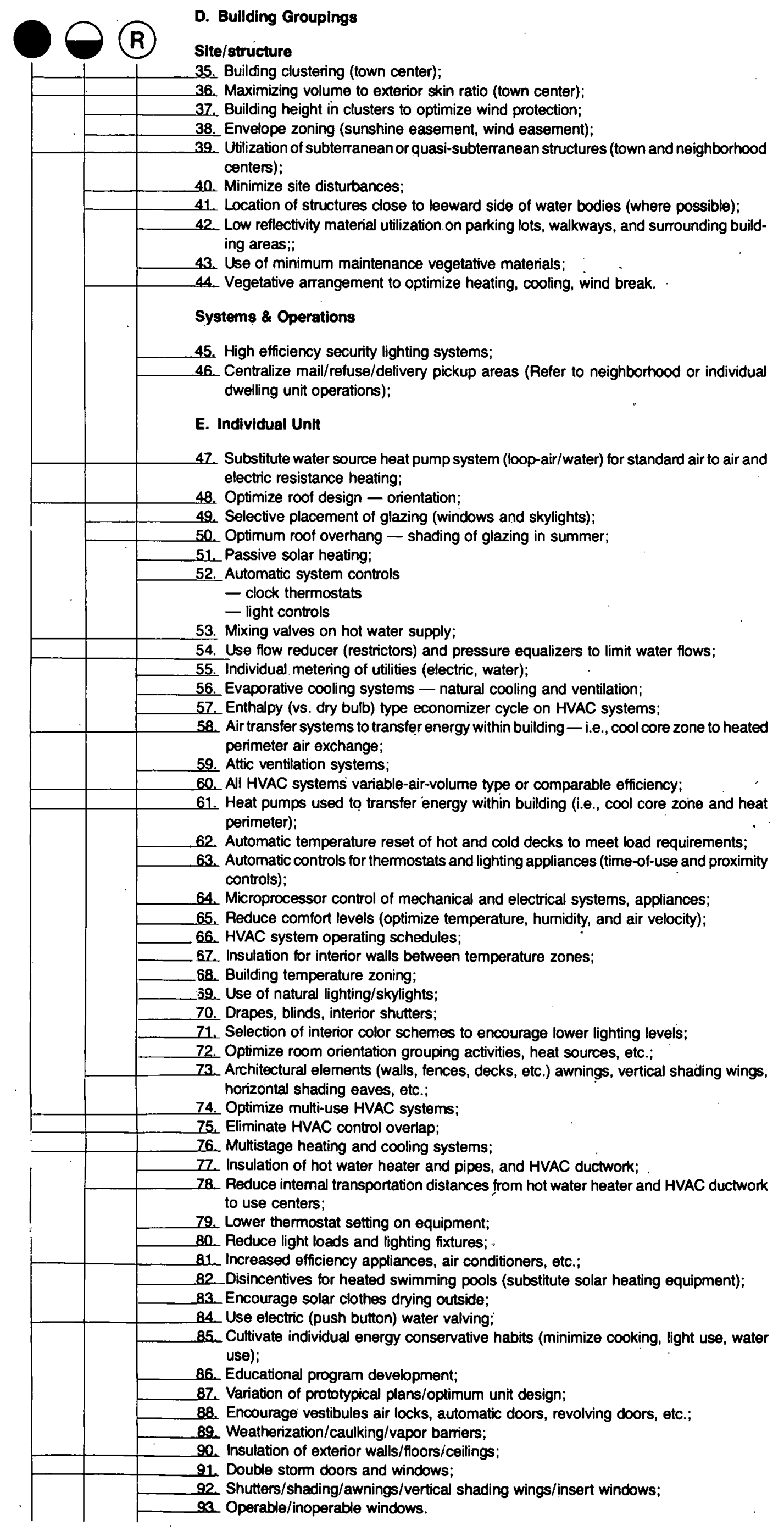




PASSED
B
FAILED

"Options 1-12 exhibited high initial cost; some provided only limited-energy savings; health code restrictions would have to be overcome for the waste and water options. Fairfax County already furnishes some refuse recovery."

1. Dual water supply systems

2. Collection and utilization of storm water - storm water retention ponds

3. Sludge utilization and energy recovery systems

4. Land application of wastewater

5. Sludge/organic waste reduction composting facilities

6. Refuse recovery systems

7. Fire protection water supply system separated trom potable water supply - utilization of chemical additives to improve flow and fire fighting characteristics of water.

8. "White" water reuse fornonpotable uses (e.g., toilet flushing, lawn sprinkling, etc.)

9. Pneumatic refuse collection systems

10. Utilize on-site alternate energy sources (solar, wind, water)

11. Instantaneous water heaters

12. ACES Annual Cycle Energy System

\begin{tabular}{cc}
\hline PASSED & FAILED \\
ABD & $\mathrm{C}$
\end{tabular}

"Options 13-15. The study area is located almost entirely on a gentle sloping north slope. The topography and water supply does not make pumped storage an attractive option for this site."

13. Pumped water storage/low-voltage power generation

14. Reductions in community development on northerly slopes

15. Location of open areas and light use areas on north slopes

PASSED
ABCD

"Options 16-25. Site use, climate, and community characteristics do not lend themselves readily to these options; high initial costs, zoning restrictions and marketing also have an impact on their acceptability."

16. Improved community delivery and conveyance operations (combined goods transit, full load trips)

17. Institution of community rail shipment services

18. Elimination of intra-, inter- community shipment of goods via large single vehicles (semi-trucks)

19. Traffic conveyance system optimization; micro-processor traffic light control systems, time-of day traffic control systems

20. Pipeline shipment of goods

21. Police, fire protection, medical integrated alert systems

22. Electric, gas, telephone systems optimization

23. Individual dwelling unit garbage/trash grinder system with treatment at sewage treatment facilities

24. Industrial park complexes - cogeneration, combined water treatment systems, zero-discharge technology, resource co-utilization, water-steam-power coutilization.

23. Utilization of subterranean structures

\begin{tabular}{cc}
\hline PASSED & FAILED \\
$A B$ & CD
\end{tabular}

"Options 26-30. High initial cost (payback greater than 10 years) and zoning restrictions eliminated these options."

26. Refuse energy generation facilities

- incineration, pyrolysis $w /$ heat recovery

27. Pipe plow installation of sewer, water, telephone, electric systems

28. Heat recovery systems on exhaust air and flues

29. District heating/cooling systems

- conventional technology ICES

- advanced cycle ICES

- Solar-assisted ICES

- coal-using ICES

- grid-connected ICES

- modular integrated utility system (MIUS)

- total energy system

30. Community monorail service system

$\begin{array}{cc}\text { PASSED } & \text { FAILED } \\ \text { B } & \text { ACD }\end{array}$

"Option 31. County uses competitive collection and disposal already."

31. Private competitive (nonmunicipal) collection and disposal of refuse

PASSED FAILED

B

"Option 32. County wide interceptors are already in place, energy savings would be minimal, high initial cost."

32. Private competitive wastewater treatment facilities.

\begin{tabular}{cc}
\hline PASSED & FAILED \\
$B C$ & $A D$
\end{tabular}

"Option 33. County and state maintain some roads, community association takes care of remaining streets."

33. Private competitive streel/highway maintenance and cleaning services.

\begin{tabular}{c}
\hline PASSED \\
BC
\end{tabular}

"Option 34. No specific commuter transfer points that would represent a large portion of study area population. County controlled, health code restrictions."

34. Commuter transfer station refuse collection system.

\begin{tabular}{cc}
\hline PASSED & FAILED \\
ABC & $D$
\end{tabular}

"Options 35 and 36. Definite marketing and institutional problems related to safe, convenient vehicle access to all areas. Exterior lighting used in many cases in residential areas instead of street lights."

35. Discourage decorative and outside lighting

36. Restricted public auto access.

\begin{tabular}{cc}
\hline PASSED & FAILED \\
ABC & $D$
\end{tabular}

"Options 37-40. Not particularly applicable to this site, difficult to assess."

37. Appliance pilot light restrictions

38. Use automatic closing valves to minimize water use

39. Automatic load shedding to reduce electrical demand

40. Photovoltaic control of lights where appropriate 


\section{Energy Conserving Applications}

The following is a description of those options that were tested and/or recommended that are included in the energy plan for Burke Centre.

\section{Off-Site Transportation}

Burke Centre is primarily a housing development serving the federal employment installations in Washington, D.C. Although the Project will contain both a convenience retail center and a larger sub-regional commercial complex, the wealth of major retail outlets and strip centers in the area insure that its residents will shop as well as work outside the project.

It is not surprising to learn, therefore, that $57 \%$ of all the energy use associated with our test parcels will be for making trips to-and-from Burke Centre. For each vehicle mile traveled within the Project there will be nearly four traveled outside its boundaries. The residents of the Test Parcels (1624 dwellings) will consume an average of over 4000 gallons of gasoline daily making trips to work, shopping and other destinations. The commercial centers will cause just under 4000 gallons to be consumed each day by patrons living outside of the project.
There are several opportunities for the community, the developer and the County to reduce the amount of travel associated with Burke Centre. Each will require a strong commitment and take several years to resolve.

1. A park-and-ride service for Burke Centre's commuters should be feasible at this time. A proposal was made through this study to provide parking at the Town Center lot for a park-and-ride system. If put into operation we have estimated a potential savings in gasoline usage equal to 2 percent of all energy consumption by the Burke Centre community.

2. Burke Centre and the communities around it could benefit from a local bus service between the residential sectors and the retail centers. The economics of a shuttle service may not.work until greater population densities are achieved in the area. The County has been encouraged to consider promoting an expanded transit system in the future.

3. A rail line connects Burke Centre to the Washington area and could provide commuter service for the community. This would require the cooperation of the Railroad, the County, Washington's METRO service, the Federal government and take a major capital investment. This service, if provided, would also depend on the feasibility of attracting a much larger market area to justify costs. The potential gasoline savings of having commuter rail service from Burke Centre to Washington merit further investigation.

\section{On-Site Transportation}

Burke Centre may be considered dense by suburban standards but, despite its inclusion of 4-plex, townhomes and apartment units, it is of too low a density to support its own public transit at this time. Also, the residents of the project are largely professional middle class, accustomed to the private automobile and, typically, owning several of them. Consequently, no attempt was made to study possible savings related to a local (on-site) public transit service.

A very detailed study was made to discover the quantity and type of energy used for moving around within Burke Centre. (See Tables 18 through 21). Notable from the findings is the fact that the study parcels, including the Town Center, will generate 31,000 vehicle miles of travel daily within Burke Centre. Given the average car on the road today, this will require over 2100 gallons of gasoline. The largest single trip generator will be the Town Centre, accounting for nearly half the mileage. The resultant BTU requirement equals 15 percent of all energy use by the project, just 6 percent less than that consumed within all of the building space studied.

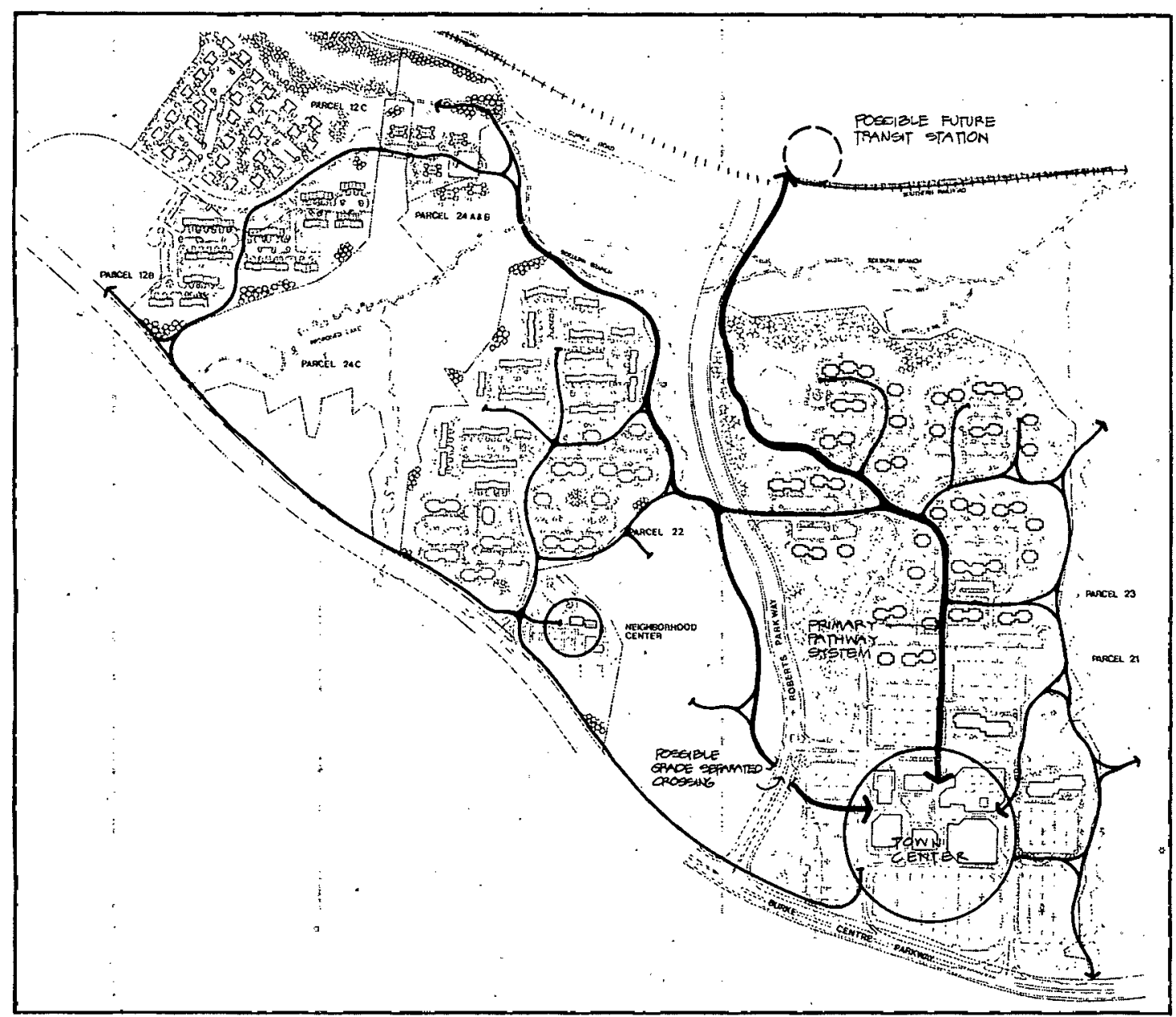


The use of gasoline on-site can be affected by several planning considerations. The most obvious, the primary collector system and land use plan, were already decided well before our study commenced. No attempt was made to evaluate their energy efficiency qualities. We did attempt to adjust the road patterns within the study parcels. In one respect we had no positive impact whatsoever. The total linear feet of on-parcel road remained virtually the same after our land planning revisions as in the Base Plan. The other factor, the number of stops, light and other type intersections were reduced. According to our calculations, 18 percent of all on-site gas usage would occur while autos were stopped in traffic. The equivalent gallonage is 381 per day. By reducing the number of intersections from 52 to 40 , this consumption figure was lowered to 324 gallons. The savings of 57 gallons amounts to 2.7 percent of all on-site fuel usage.

Our other attempts to deal with reducing vehicle miles included the use of a path system to encourage walking and bicycle use. We limited the paths to connecting the housing next to the Town Center to the commercial complex. Expecting any significant substitution of human energy for the car for trips of greater length seemed remote at this time. We estimate that a 100 percent use of the path system by the residents of these 936 units would reduce total on-site gas consumption by 1.2 percent. $A$ more realistic estimate would be perhaps a fifth of that amount.

The creation of a compact commercial complex in the Town Center produced a daily gas-use reduction of 13.5 gallons. This resulted from placing offices, retail and recreational facilities within walking distance of each other.

Overall, we were able to reduce on-site gasoline usage by about 3 percent from the Base Plan.

\section{Heating and Cooling}

The Study Parcels contain 2,700,000 sq. $\mathrm{ft}$. of space requiring climate control. The 1624 residential units make up 85 percent $(2,298,000 \mathrm{sq}$. $\mathrm{ft}$.) of the total while the 300,500 feet of commercial space and 90,500 feet of recreation uses contain the rest. We estimated that the heating and cooling of this space would involve about $60 \times 10^{9} \mathrm{BTU} / \mathrm{yr}$. This would cost the consumer around $\$ 400,000$ a year at today's VEPCO rates. Heating and cooling represented 45 percent of the Base energy usage in the buildings and about 10 percent of the total energy use by the project. During our study we explored both planning and technological approaches to reducing these numbers.
In each Study Parcel we attempted where possible to maximize north-south exposures to take advantage of local wind and solar angles. In most instances we sought south slopes as building sites, used natural slopes as wind screens and dug into the ground for foundations rather than to use fill to level out land forms. Because the site was predominately wooded, we attempted to retain bands or clusters of mature trees to provide shade or protection from winds. Since, we were able to save on basic land improvement costs, we augmented the tree planting programs to supplement existing vegetation. As a result of these planning factors we could estimate a potential drop in HVAC costs of about 2 to 5 percent depending on the specific site and building type. These estimates do not reflect all of the potential positive impacts from controlled sun and wind conditions since many have never been fully field tested. Further, one of the advantages of proper building orientation, that is, the active use of solar gain in buildings, was not quantified at all in this study.

After considering the alternative equipment available to control building temperature we selected the water-to-air heat pump system for testing. From a cost perspective, the use of ground water recycled back into the aquafer after use is the most efficient. We investigated the availability of sub-surface water at Burke Centre and found a potentially adequate resource. There are no regulations existing that prohibit its use for this purpose. We therefore incorporated the use of this natural resource to increase operating efficiency of our heat pump option.

\section{Water Saving Devices}

The provision of potable water and the treatment of wastewater has become a primary determinent of where new development will and will not go. The overall cost of providing public water and sewerage treatment has risen dramatically during the 1970's with increased environmental regulations and residential consumption. While federal funding programs emphasized support of trunk line extensions and plant construction during the 1960's, they now concentrate on upgrading the quality of treatment. The resulting increase in the value of each gallon of water that flows through a home is evidenced by the dramatic increase in public water rates throughout the country.

Part of the cost of producing and transmitting potable water is the amount of energy it consumes. The same is true for the collection and treatment of liquid sewage. For our test sites in Burke Centre these functions consumed 6 percent of the total projected energy use and 15 percent of all on-site consumption (excluding off-site transportation). More directly, the energy consumed for water and sewer service represents about one fourth of all electricity supplied to the project by the local power plant. Because of the tremendous losses in the production of electricity it takes as much energy at the generator to create electricity for water and sewer needs as it takes energy going into Burke Centre for all of its heating, cooling, lighting, hot water and appliance needs.

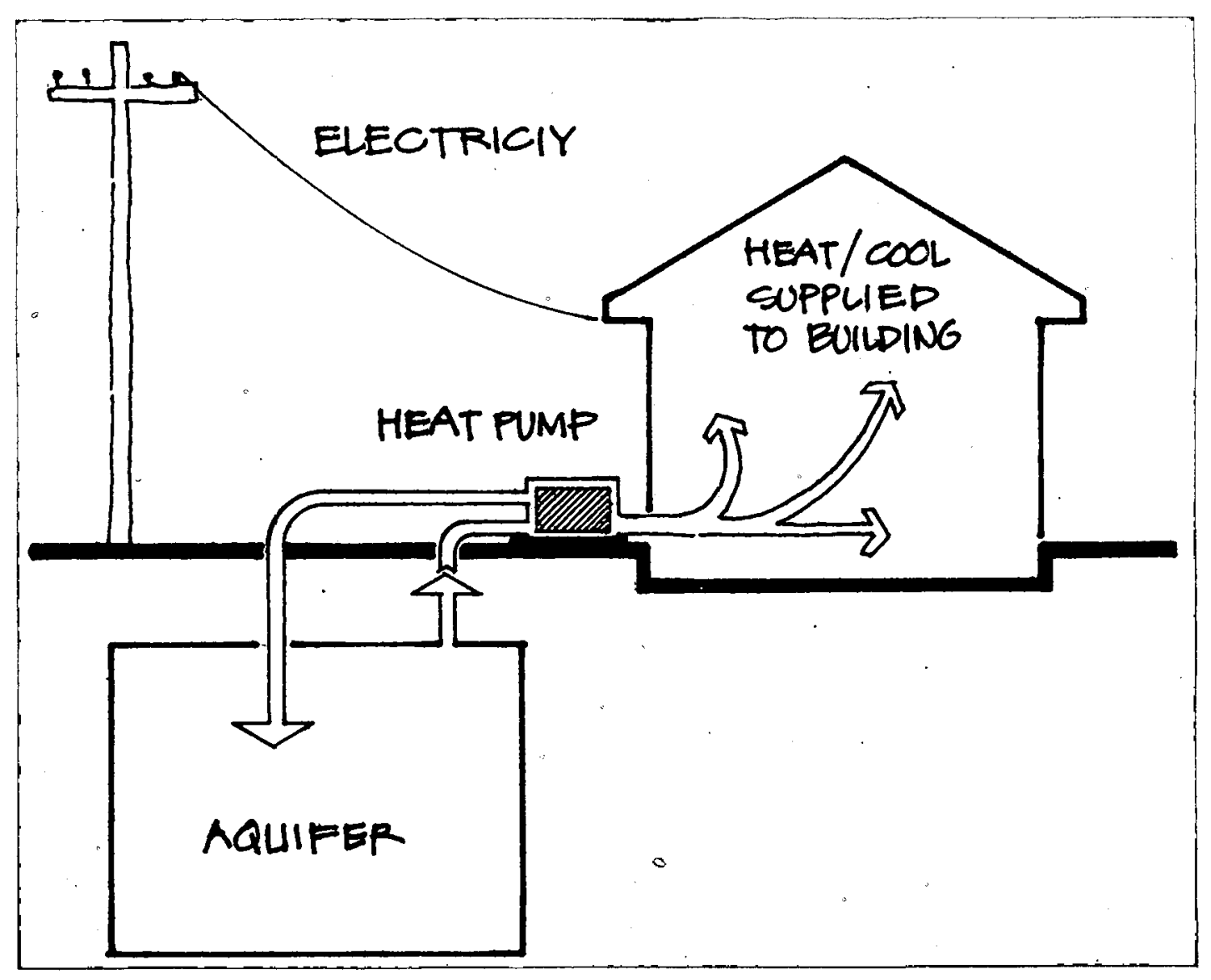


Table 24. Burke Center Anual Water Usage and Wastewater Treatment Requirements By Parce

\begin{tabular}{|c|c|c|c|c|c|c|}
\hline \multirow[b]{2}{*}{ Parcel } & \multicolumn{2}{|c|}{$\begin{array}{c}\text { Water Usage } \\
\text { Usage }\end{array}$} & \multicolumn{2}{|c|}{$\begin{array}{l}\text { Wastewater } \\
\text { Treatment }\end{array}$} & \multicolumn{2}{|c|}{$\begin{array}{l}\text { Total } \\
\text { Energy } \\
\text { Used }\end{array}$} \\
\hline & Base & $\begin{array}{l}\text { (r.) } \\
E / C\end{array}$ & Base & $\begin{array}{l}\text { rr.) } \\
E / C\end{array}$ & \multicolumn{2}{|c|}{$\begin{array}{l}\text { B.P. } \quad \begin{array}{l}\text { Plan } \\
\left(10^{6} \mathrm{Btu} / \mathrm{Yr} \text { r. }\right)\end{array}\end{array}$} \\
\hline High rise (23) & 23 & 13.5 & 20.7 & 12.02 & 6.5 & 3.8 \\
\hline Gardens (23) & 42 & 25.5 & 37.8 & 22.7 & 11.8 & 7.0 \\
\hline Gardens (22) & 18 & 10.6 & 16.2 & 9.5 & 5.0 & 3.0 \\
\hline Cluster (24 A \& B) & 4 & 2.4 & 3.6 & 2.2 & 1.1 & 6 \\
\hline 4 -plex (12C) & 10 & 5.9 & 9.0 & 5.3 & 2.8 & 1.7 \\
\hline Townhouse (22) & 18 & 10.7 & 16.2 & 9.6 & 5.0 & 3.0 \\
\hline Townhouse (12B) & 11 & 6.2 & 9.9 & 5.6 & 3.1 & 1.7 \\
\hline Recreation Fac. & 6.2 & 1.7 & 5.7 & 1.6 & 1.7 & .4 \\
\hline Office & 12.0 & 6.6 & 10.8 & 5.9 & 3.4 & 1.9 \\
\hline Retail & 6.4 & 3.5 & 5.8 & 3.2 & 1.8 & 1.0 \\
\hline TOTALS & 150.6 & 86.3 & 135.7 & 77.8 & 42.2 & 24.1 \\
\hline
\end{tabular}

Reducing the consumption of water is a relatively simple and inexpensive proposition. We have calculated the potential savings in water usage that could be derived from the following devices.

The impact of using these devices as the consumption of water is shown by Table 24. The total reduction in energy consumption for the test sites is $18.1 \times 10^{9} \mathrm{BTU} / \mathrm{yr}$. The reduction in actual water usage is estimated at 64 million gallons per year, or 175,000 per day. Using the reduced consumption figures (a reduction of $35 \mathrm{gal}-$ lons per day per capita), an additional 1200 dwellings could be served by the savings on the test sites. The implications, over and above energy usage, are worthy of the consideration of developers, builders and local communities.

\section{Hot Water Usage}

The 1624 residential units in our combined study parcels will consume $35.5 \times 10^{9}$ $\mathrm{BTU} / \mathrm{yr}$. of electric energy to heat water. The cost of this service is a quarter of a million dollars. It represents 32 percent of all the energy that will be consumed within the homes of Burke Centre.

There is little the developer can do, directly, to reduce this extravagant use of electric power. Home builders, however, can play a role in both educating the buying public and equipping residences with hot water conserving devices. In the section discussing water consumption generally we itemized a number of techniques for reducing total water use. Several of these involve hot as well as cold water. Appliances such as dish and clothes washers are now available at competitive prices that vary or reduce hot water volumes. Mixing values on shower heads reduce cold water volumes and, consequently, the amount of hot water used. Flow restrictors on other taps can cut volumes from 10 to 5 gallons per minute. These are all simple, available and inexpensive devices that can be installed in today's new homes. Any market resistence to houses so equipped should be susceptible to an educational program by the building industry.

After incorporating all of the energy conserving features tested during this study the allocation of domestic energy to heating water came down by 5 percentage points. More important than this relative decline was the absolute drop in consumption of almost $15 \times 10^{9} \mathrm{BTU} / \mathrm{yr}$. or a 42 percent reduction.

\section{Solid Waste Removal}

The use of commercial and public vehicles to provide a variety of services to the Burke Centre community is a fertile field for exploring new systems, vehicles and equipment. As noted in the Options Screening section, we declined to study a number of these services such as postal collection and delivery because of the lack of available technology today.
Reducing energy consumption in the services provided to communities may also require some difficult changes in American's lifestyle. Particularly in metropolitan areas such as Fairfax County, the expectations for efficient collections and delivery are high. So, too, is the demand for convenience. Centralized points for drop-offs and deliveries are not part of our normal living patterns. For this reason we abandoned the study of such service patterns as central solid waste deposit areas. The negative effect on Burke Centre marketing program could well exceed the energy savings at this point in time.

One approach that was studied involved the use of modern packer trucks for collecting solid waste throughout the community. The study parcels will produce an estimated 8,300 tons of solid waste annually. By conventional collection standards (as now in use in Fairfax), the demand for diesel fuel to remove this trash would exceed 20,000 gallons. The use of more efficient trucks could reduce the load trips per year by 40 percent on the average. The resulting savings in diesel fuel would be nearly 8,000 gallons.

This is obviously a small component of the total issue of reducing fuel consumed by police and fire vehicles, the delivery of mail and the delivery of commercial consumables to homes and business establishments. Each of these should be studied on their own merits to determine the potential for conserving fuel within technological, industry and marketing boundaries.

\section{Site Planning}

The following items represent those design techniques and community operational processes that were included or recommended for inclusion in the physical plan for the energy conserving solution. As previously noted, the limits of the study prevented the accurate quantification of the energy conserving potential of many of these options. However, the ability of those items not tested to modify micro-climates and conserve energy is widely understood even though accurate figures have not, as yet, been developed. For this reason we felt obligated to include all these options which survived the screening process into the physical plan for energy conservation. 
Topography and Orientation Orientation of a building is critically important for both passive and active solar utilization. The more easily a building can be manipulated on the site to obtain proper orientation the cheaper the site development costs related to site preparation, earthwork and access.

This basic site planning premise initiated a major effort to modify the base plan in a way that would increase the percentage of buildings in the study program that could take advantage of options possible with proper orientation.
The topography of the study sites, in many cases, worked against developing the program with proper orientation. Most of the study parcels sloped from south to north. This condition limited the ability to orient some unit types properly; for instance: only $84.4 \%$ of the townhouse buildings required by the base marketing program could be oriented on the sites to take advantage of passive/active solar. This is not to say a higher percentage couldn't have been achieved with a different architecture or alternative parking layout.
On the other hand, nearly $100 \%$ of the required garden apartment buildings were oriented properly. This can be attributed primarily to the traditionally more flexible parking arrangements possible with apartments.

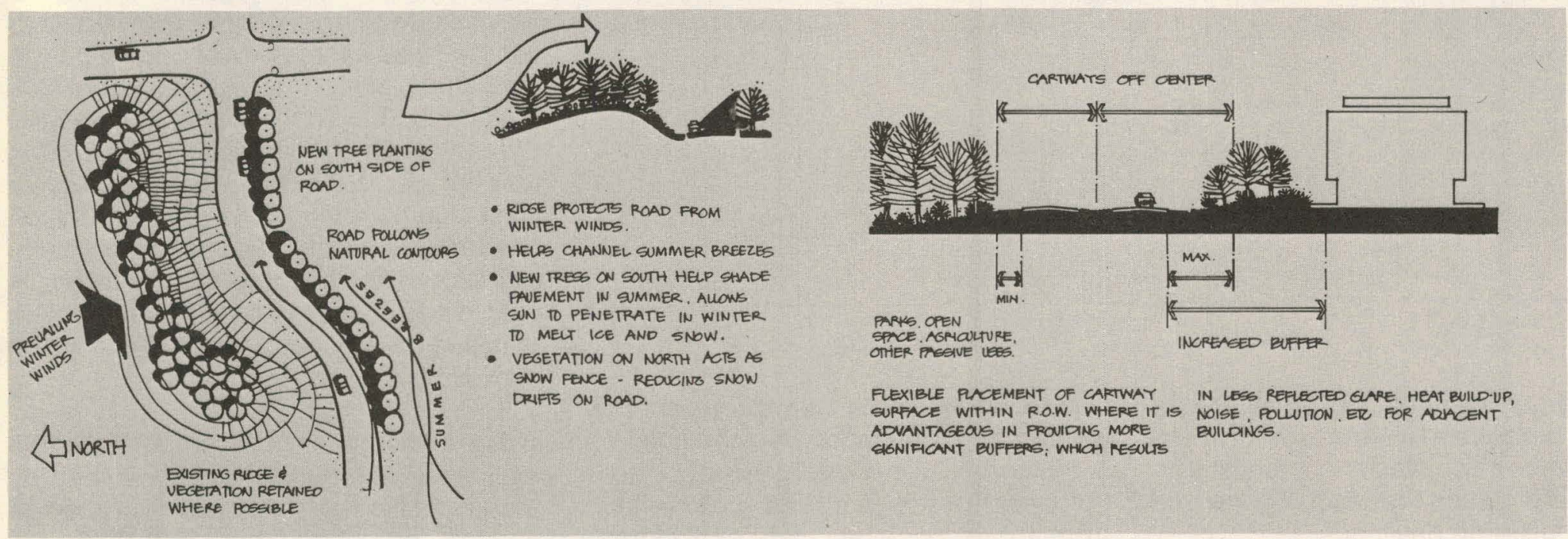

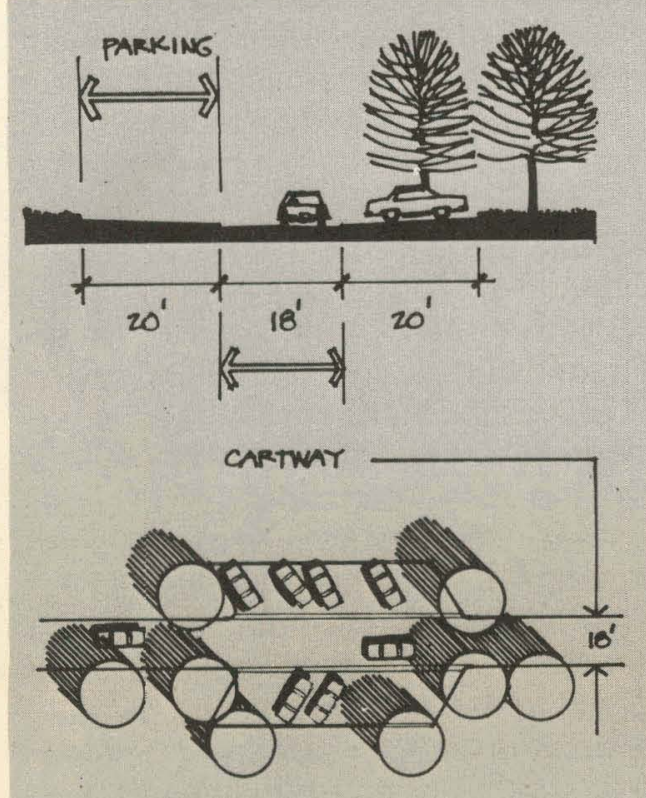

ONE WAY RESIDENTIAL LOOP

- REDUCES SITE DEVELOPMENT AND INSTALATION COSTS (EMEOLIED ENERGT). - DECTREAEES COSTS (ENERGT) For MAINT. ND REPLACEMENT OP PANED SURAACES - INCREASES tTHE EFfectuenegs of PROPERLY PLACED STMDE TREES

- REOUCES STORM RUN.OFF. HEAT EUILD.UP. AND TRAFFIC SPEED

Figure 26. A-C Roadway and Paving

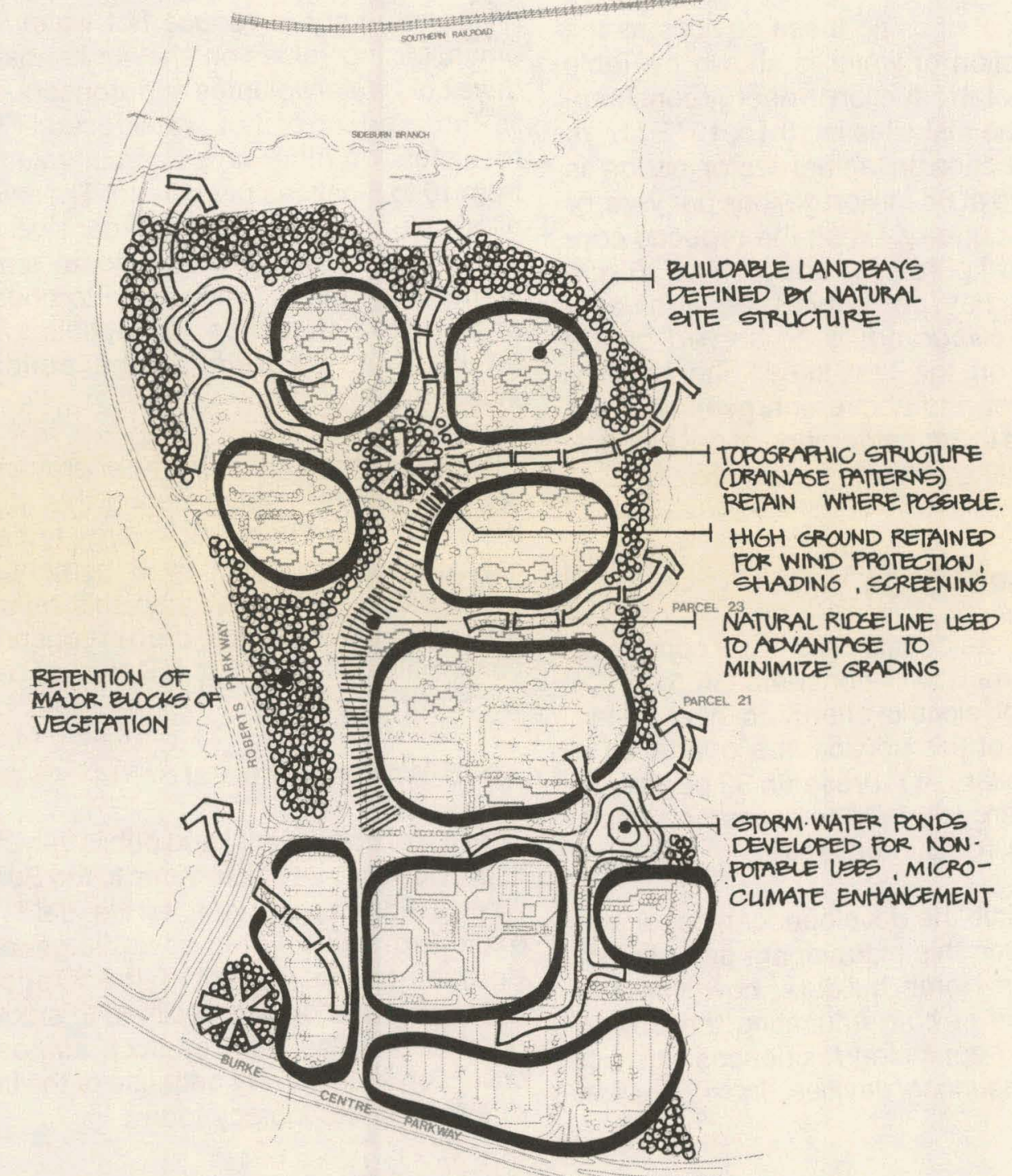


Clustering The clustering of buildings has long been recognized for its benefits related to development costs and efficient use of land. As a concept it also can provide certain economies in the use of energy. By clustering the commercial, office and recreation uses in the town center a number of energy saving opportunities

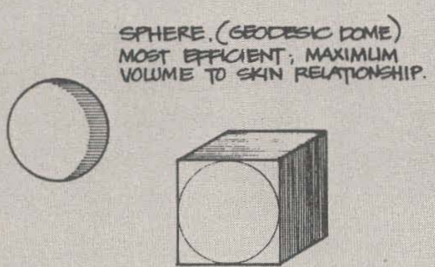

CUBE NEXT BOST SHAPE.
PRESENTS SOME PROELEMS

WITH INTE

DESIGN OBIECTIVE:

MINIMIZE ERTERNA WML TO

VOUME RATO IN BUIDOINOS
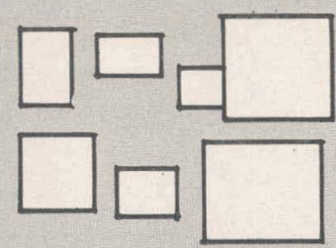

INDIUIDUAL BUILOINGS IN TOWN GENTER PROSPAM ARE KEPT SIMPLE IN FORM. were possible. The ratio of exposed building walls to volumes enclosed can be significantlv improved using the cluster technique. The building shapes for the various uses in the town center became more flexible using a cluster format and thus proper orientation was easier to achieve.

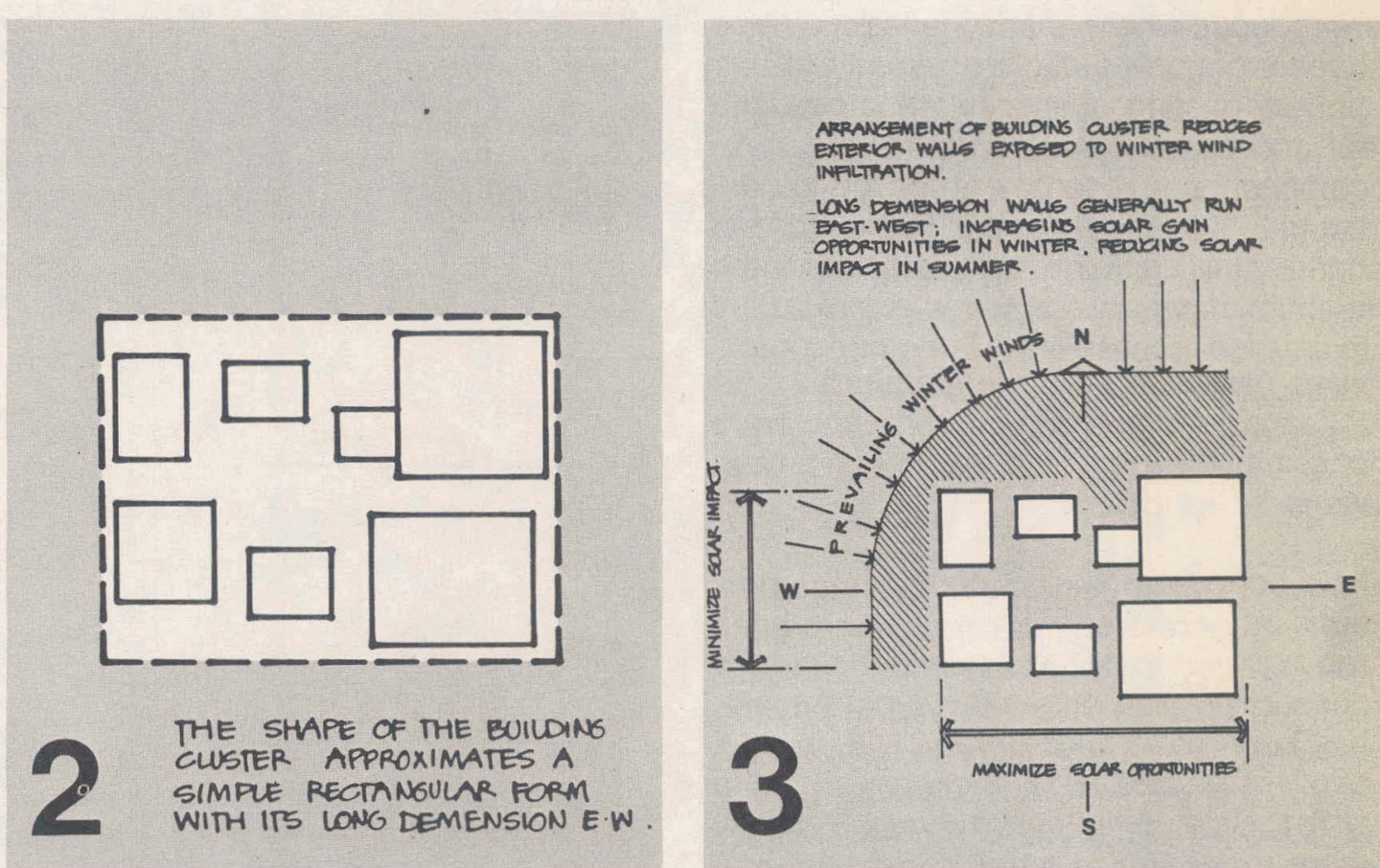

The more compact development requires less physical space on the site to accommodate the same. program. Opportunities to share parking between uses is more likely to be feasible in a tightly clustered development, thus reducing paved surfaces (and storm drainage requirements). Utility runs are shortened and access to and within the center becomes more efficient.

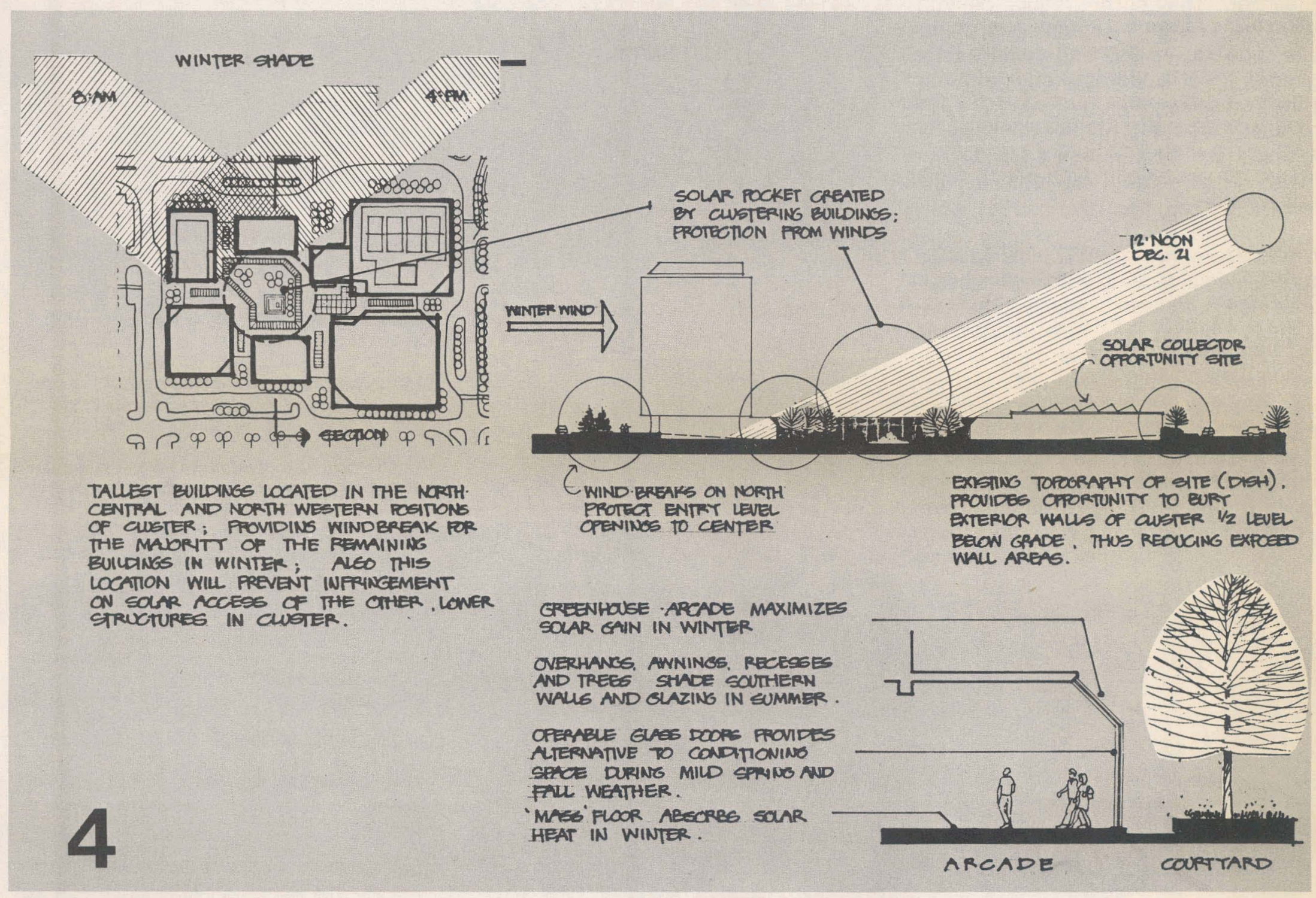


avement Design A number of design hanges were incorporated into the nergy conserving plan to reduce paved urfaces. In some cases, substitutes for etroleum based surfacing materials were ised.

an effort to reduce pavement areas equired for parking several design echniques were used. Parking spaces vere reduced where sharing was possible etween non-conflicting uses. Smaller referred parking spaces were provided or mo-peds, bikes, electric and subcompact cars. A recommendation to contruct $8-10 \%$ of the remote fringe areas of parking lots as overflow, to help reduce the amount of impervious cover, was included $n$ the plan. Access lanes in the parking lots vere narrowed from the standard $24^{\prime}$ to $23^{\prime}$ and where bumper overhangs were cossible the depth of the parking bays vere reduced to 18 .

Von-petroleum based paving materials such as concrete unit pavers, have been ecommended for wider use in the energy conserving plan. While this type of paver nas been used successfully in Europe, it nas not gained wide acceptance in the J.S. to date. Even though they are slightly more expensive to install initially, they require little or no maintenance and last ndefinitely. They do not require destrucion of the pavement surface to accommodate repair to utilities and could reduce summer heat build-up, reflection and glare. A disadvantage under today building techniques is the labor intensive installment required. Future costs for asphalt products could off-set this initial disadvantage.

Where appropriate, road widths were reduced, particularly, in residential neighborhoods with light traffic volumes. In some situations $18^{\prime}$ wide - one way streets with no 'on street' parking were incorporated into the plan. Collectively these measures significantly reduced the imbodied energy and costs for installation. The operational energies consumed for maintenance, repair, snow removal and lighting are also reduced by these measures.

Figure 29. A-D Parking Concepts
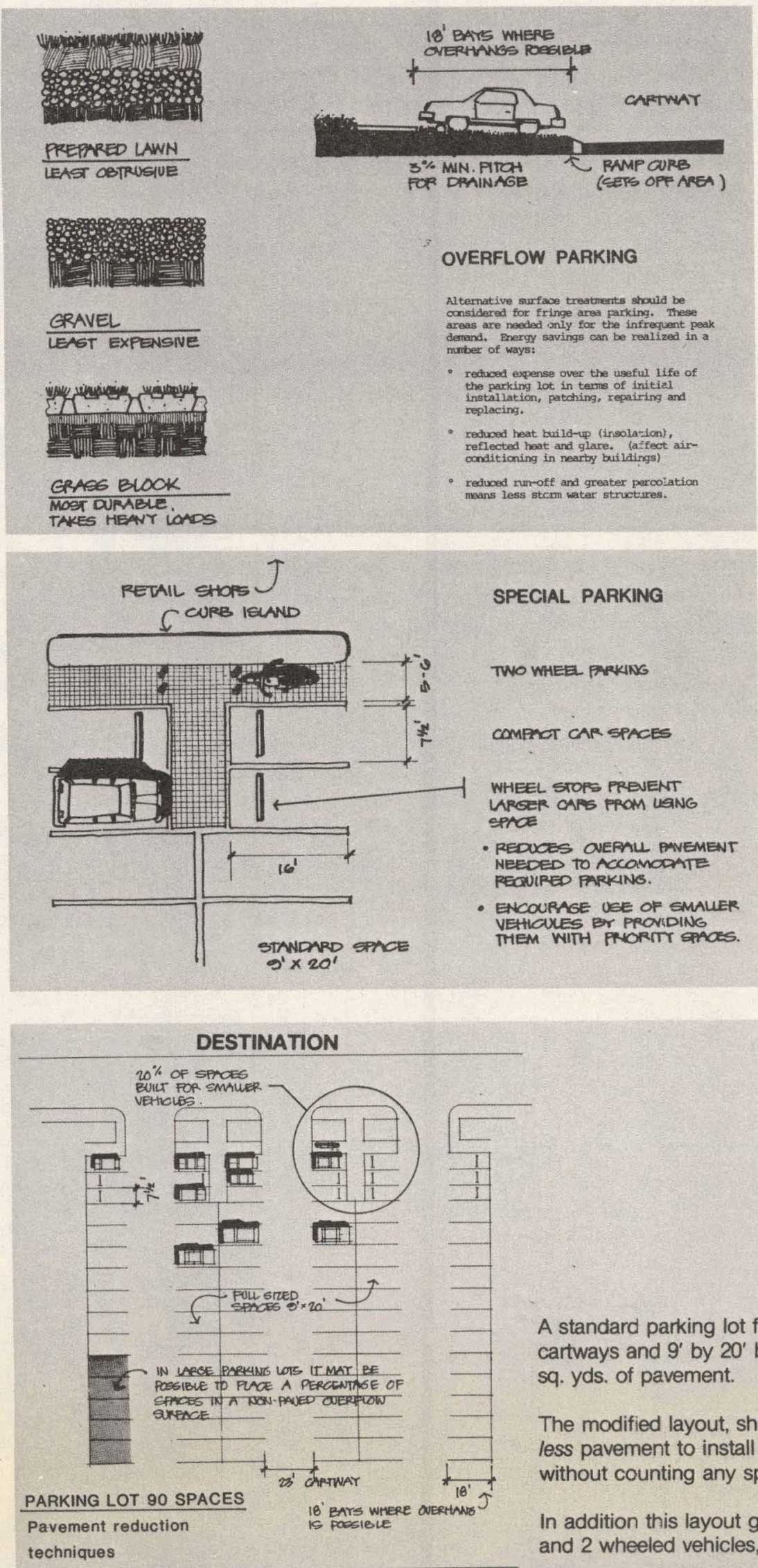

A standard parking lot for 90 cars using 24' cartways and ' 9 ' by $20^{\prime}$ bays would require 2,880 sq. yds. of pavement.

The modified layout, shown, required 200 sq. yds. less pavement to install and maintain (calculated without counting any spaces as overflow).

In addition this layout gives priority to smaller cars and 2 wheeled vehicles, encouraging their use.

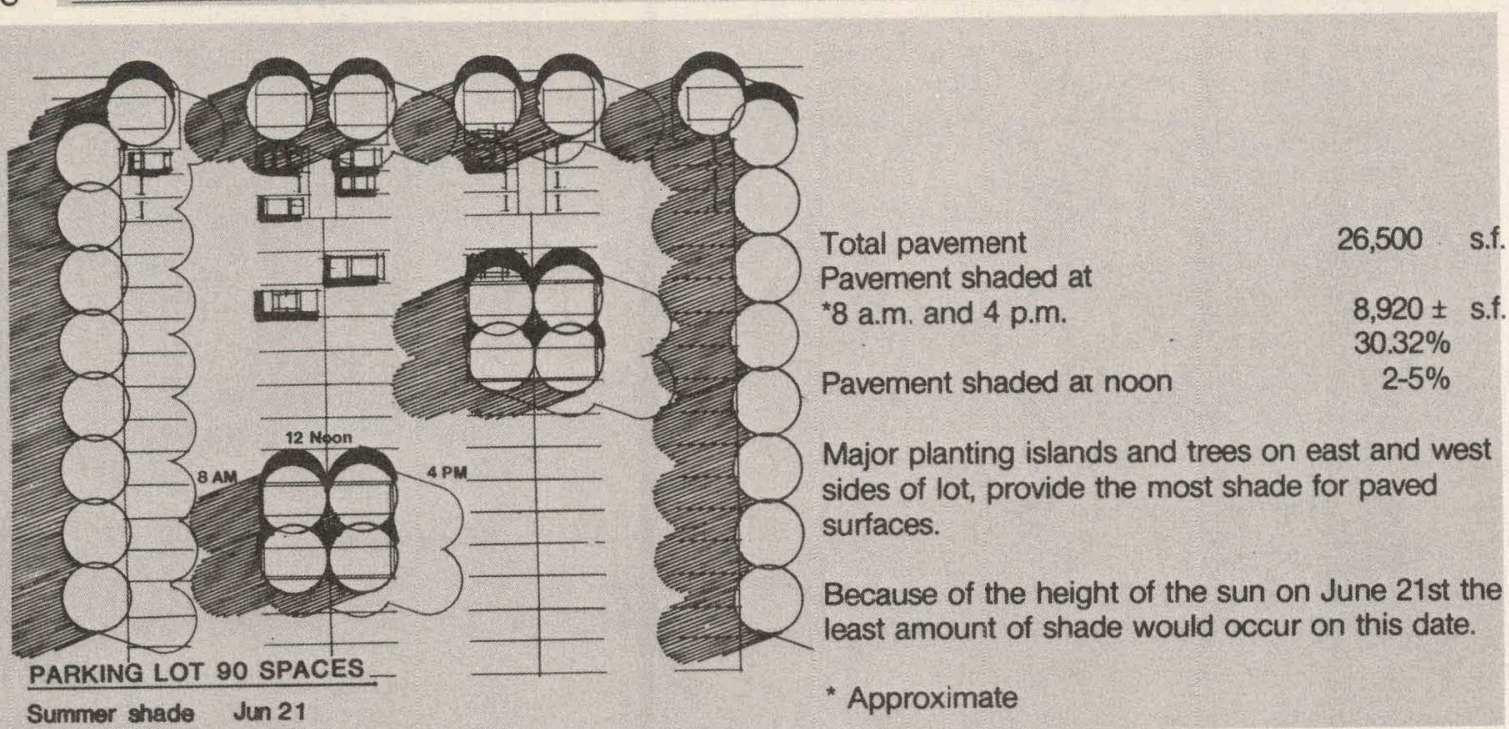


Notes on embodied energy in asphalt pavements: Abstracted from:

Asphalt Institute Report (BTU figures only)

April '75 M.I.S.C.-75-3 "Energy Requirements for Roadway Pavements"

The energy required to produce and install one square yard of asphalt paving material at a depth of one inch is 27,800 BTU.

A full depth asphalt road or parking lot $\left(5^{\prime \prime}\right)$ would expend 139,000 BTU's per square yard, and cost about $\$ 17.00$ in mid-1979 costs. ${ }^{\star}$

Reduction of a parking lot by a single space (300 s.f.) would save $4.63 \times 10^{6}$ BTU's or about * $\$ 566$. (Not counting curbing or striping).

One mile of roadway reduced in width by one foot would result in a savings of $8.15 \times 10^{7}$ BTU's or $\$ 9,975$.

In addition to these obvious expenditures in energy and dollars it must be kept in mind that asphalt pavements are only temporary surfaces. Annual upkeep, in dollars only, is usually calculated as $10 \%$ of the original installation costs (excluding inflation), with a $40 \%$ replacement of the original surface after 10 years.

Site Specific The following measures were incorporated into the $\mathrm{E} / \mathrm{C}$ plan:

Buildings were arranged for microclimate enhancement and proper orientation including location for solar access, wind protection and summer breeze enhancement.

Site plans stressed utilization of existing topography and vegetation to minimize development costs and take advantage of passive conservation opportunities.

New plantings were added to help shade, deflect winter winds, enhance summer breezes and minimize pavement heat build-up.

Low maintenance paving and plant materials were used where possible, particularly adjacent to buildings.

Where possible storm water was collected in retention ponds to modify the micro-climate of adjacent areas and provide opportunities for non-potable water uses; such as, fire protection, irrigation, car wash stations, etc. Pond sites can also provide passive recreation within easy walking distance of residential neighborhoods, reducing auto trips for this activity.
Community Services The E/C design enhances the efficiency of delivering community services to reduce the energy required for these functions. A logical and efficient hierarchy of community roadways improves the efficiency of refuse collection, mail delivery, and fire/police protection. Elimination of on-street parking removes barriers to efficient delivery of these services. Standardizing refuse containers and clustering of pick-up and delivery points (particularly for non-residential uses) is recommended for improving efficiency and reducing the energy required for these functions.

Certain governmental policies, lifestyle and marketing concerns, may make some of these changes difficult to initiate.

Utilities Since major trunk lines were in place for sewer and electric service at the outset of our study little impact was possible on these facilities. However embodied energy in construction and long term operation energy for maintenance was reduced through a variety of site specific planning and design techniques. Such as:

a. clustering of end users to minimize utility runs;

b. reduction of impervious surface, elimination of unnecessary curbing, and retention of natural site drainage structure, to minimize storm drainage systems;

c. compact, multi-use development of activity areas (commercial/retail, office/ employment, recreation and institutional uses) to maximize efficiency and reduce the quantity of site lighting necessary.

d. single trench, easy access, utility r.o.w.'s where possible, were recommended. Pre-servicing conduits as part of initial utility installation, for possible future systems (cable TV, emergency alert, etc.). This last recommendation would require changes in institutional policies for installation, operation and maintenance and some engineering problems would have to be addressed. (i.e., water service adjacent to electrical conduit, potable water with sanitary sewer, etc.)
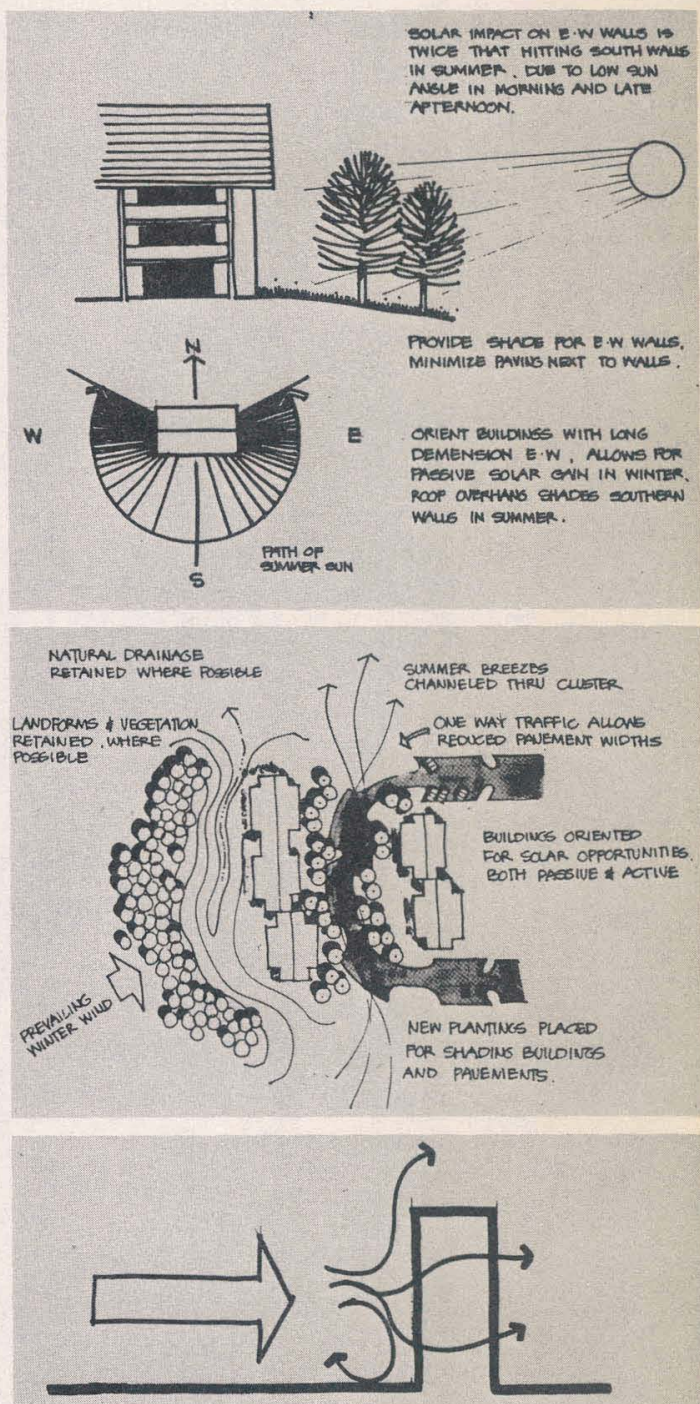

WIND INFILTEATION ON NORTH

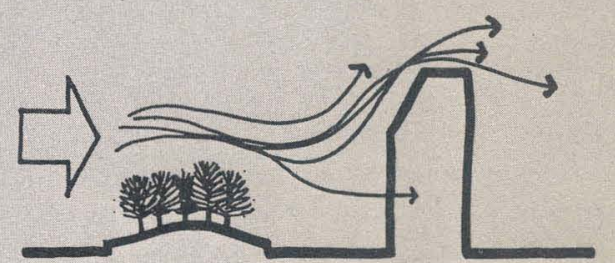

THE USE OF EARTH MOUNDS, NATURAL LAND FORMS OF EUILINS MASSES CAN HELP MINIMIZE INFILTRATION.

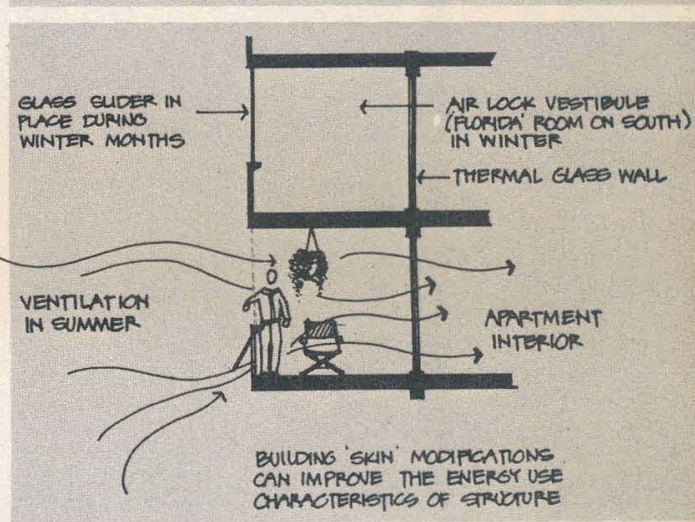

Figure 30. A-D Site Planning \& Bldg. Orientation 
Building Modification The differences between the residential units in the base plan and the energy conserving plan are minimal. The builders at Burke Centre are already exceeding $\mathrm{R}$ factor requirements for walls and roof surfaces in most cases.
Insulated glass for sliding doors and windows is commonly installed in most new residential construction. Such techniques as extended roof overhangs on southern orientations, the use of air-lock vestibules, and selective placement of glazing were recommended as worthwhile options for builder consideration.

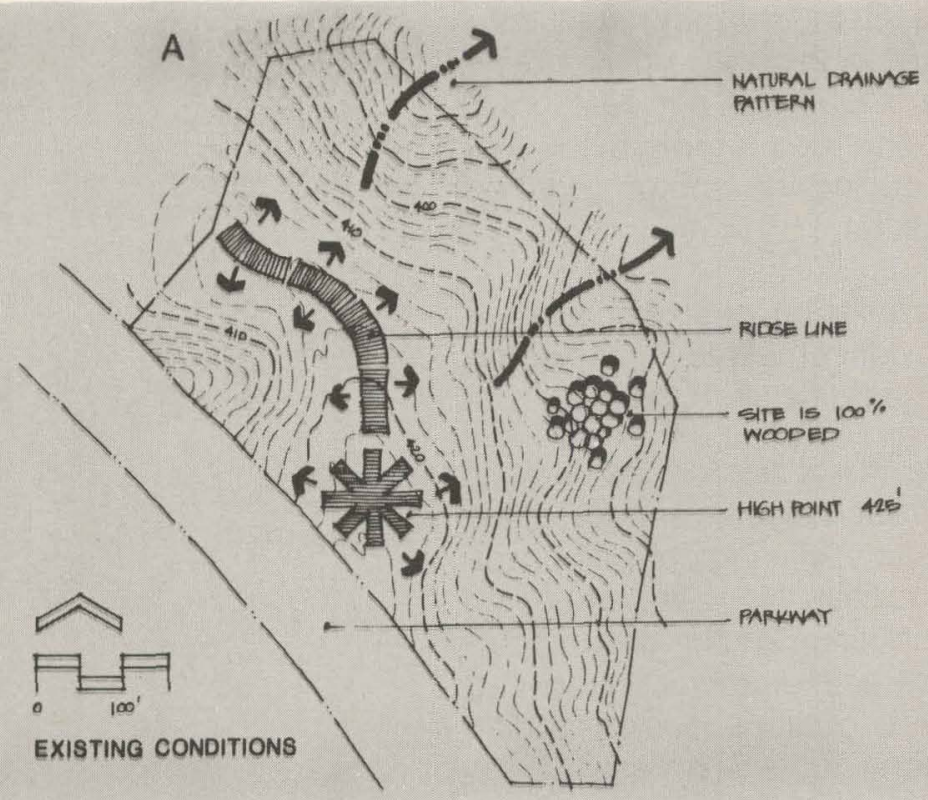

In the town center a number of specific modifications were proposed and incorporated into the energy conserving plan. They included:

Cluster many uses together;

Minimizing exterior wall surfaces exposed to weather extremes; the east/ west walls in summer and the north and west walls in winter;

Minimized roof surfaces through stacking of uses; i.e., office space over retail, or recreation in a multi-level configuration;

Orientation for active/passive solar utilization;

Reduced glazing on north/west exposures. Shade glazing from summer sun; Allowed for natural ventilation where possible;

Minimized paving next to structures.

\section{Figure 31.}

A-F Site Planning for Neighborhood Center

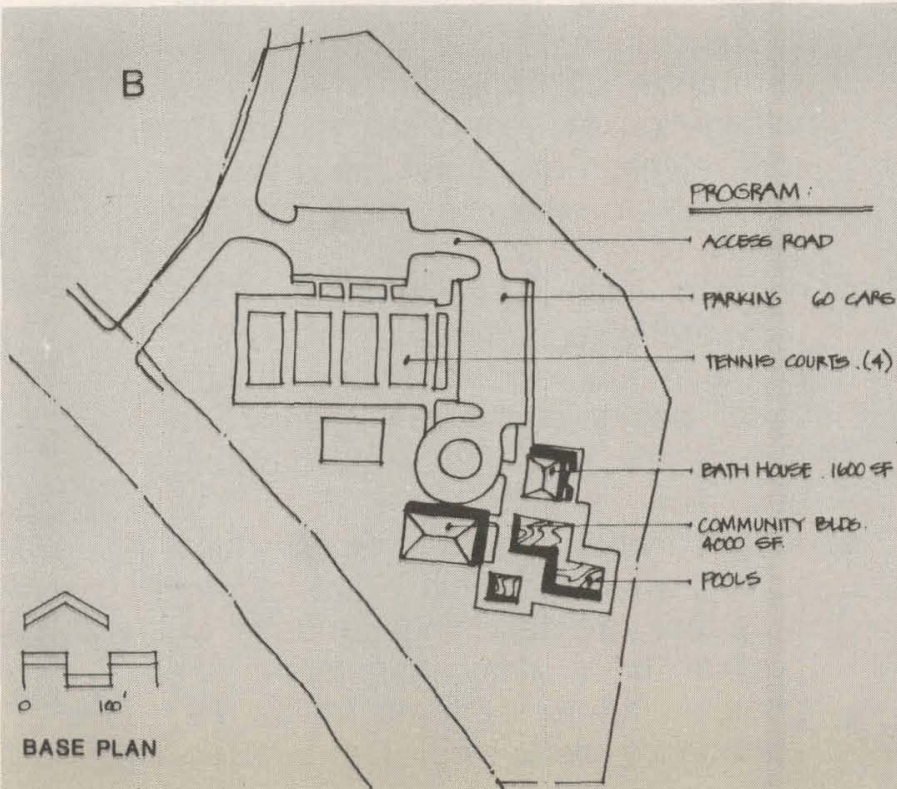

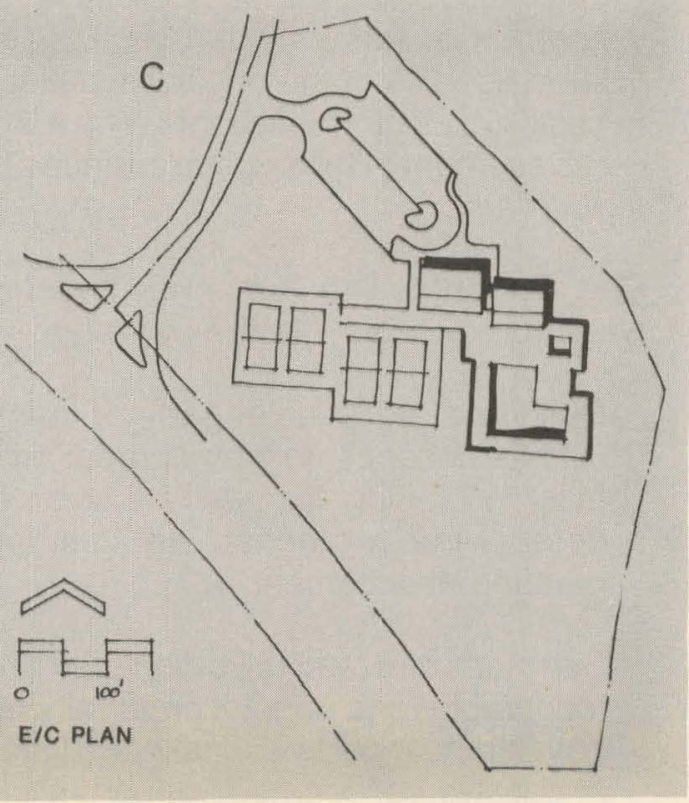



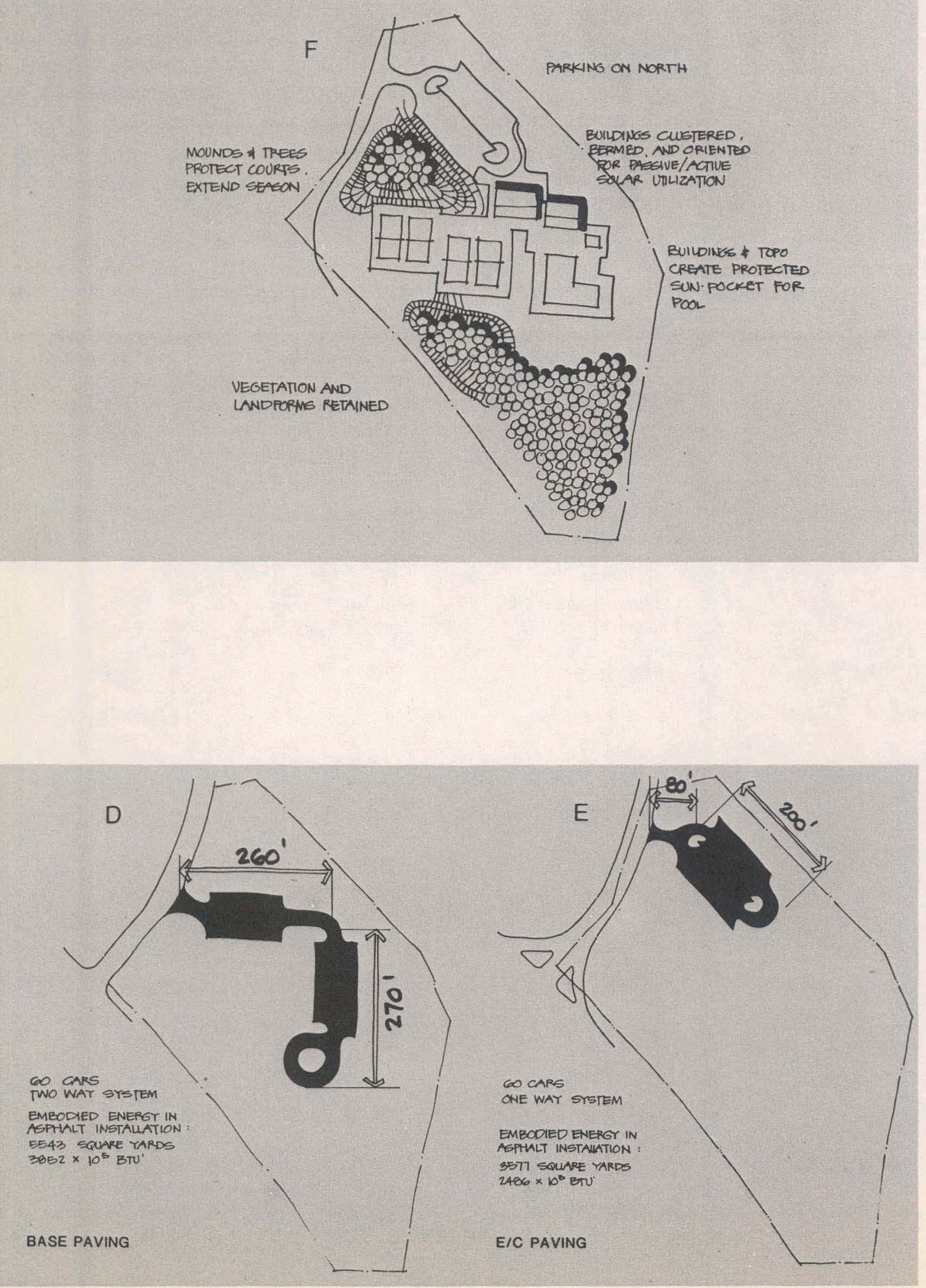


\section{Plan Evaluations}

The following tables quantify the basic physical parameters of the two plans and highlight the differences between them. Some of these figures were used to help develop the energy profiles for the base and energy conserving plans, while others were quantified for determining differences in site development costs.
The energy conserving plan shows an $18 \%$ reduction in site development costs. The site development costs for the conventional (base) plan total $\$ 11,519,519$ as compared to an energy plan total of $\$ 9,415,058$. The greatest savings can be attributed to reduction in pavement, reduction in lengths of utility lines, and adapting the site plan to follow the natural contour of the land.

Table 25. Plan Evaluation

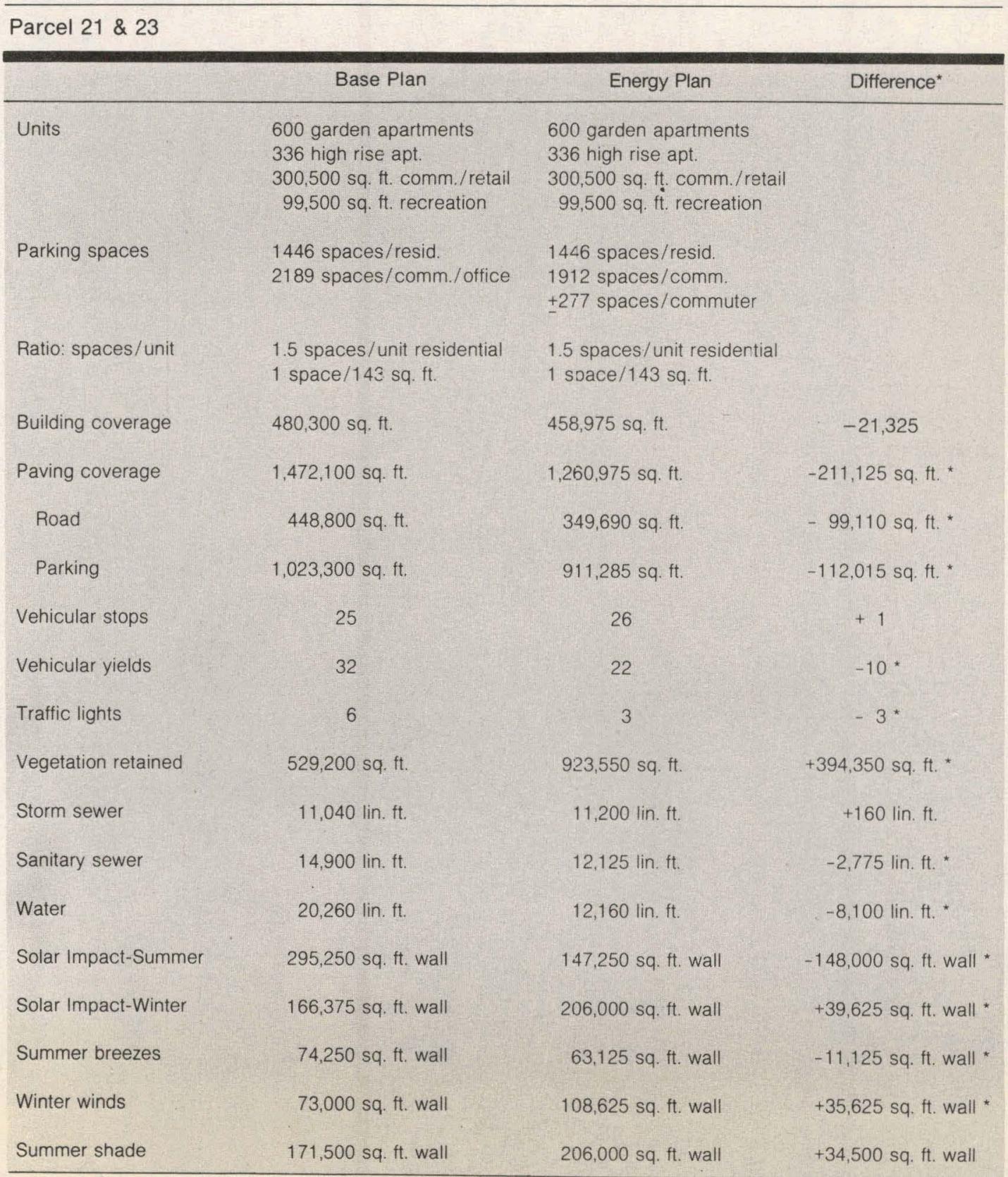

The energy conserving plan reduced site development costs of pavement and curbing by $\$ 947,026$; utility lines by $\$ 467,688$; and earthwork by $\$ 1,114,645$. (See appendix for detailed cost breakdowns for the various study parcels). 


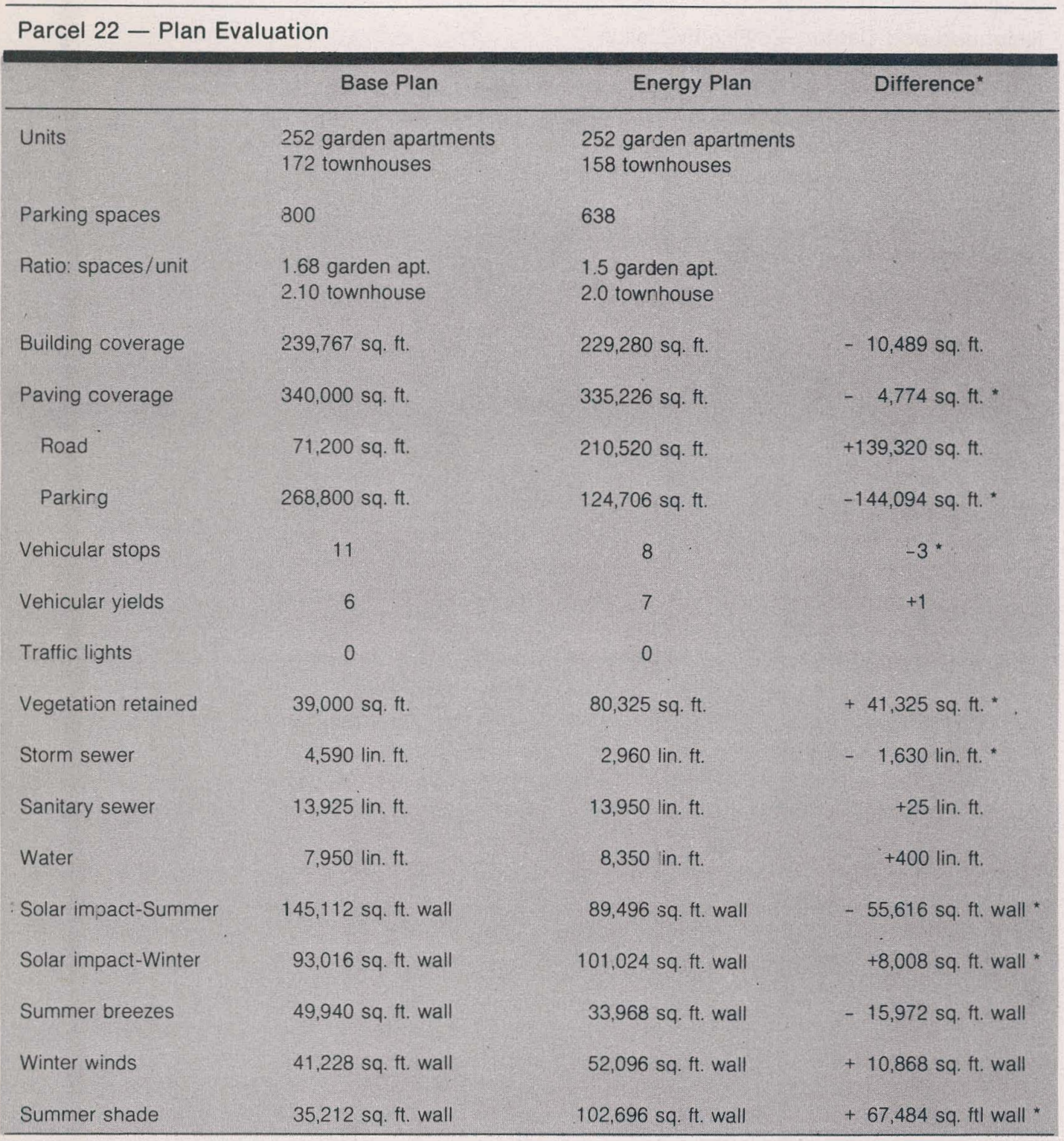

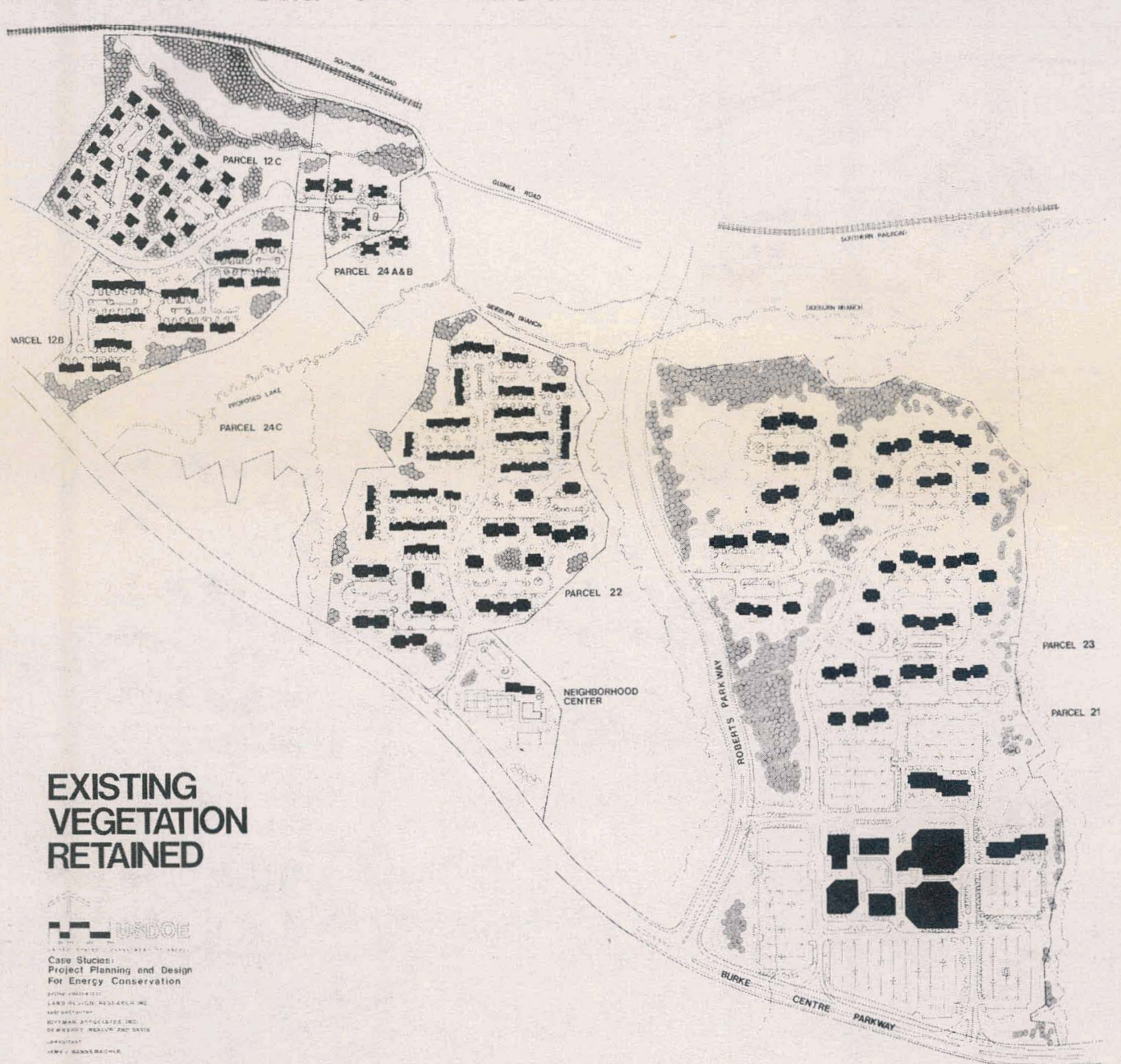

Figure 32. Energy Plan - Existing Vegetation Retained 
Neighborhood Center - Plan Evaluation

\begin{tabular}{|c|c|c|c|}
\hline & Base Plan & Energy Plan & Difference \\
\hline Units & Bathhouse/community center & Bathhouse/community certer & -86 lin. ft. wall * \\
\hline Parking spaces & 54 & 60 & +6 \\
\hline Misc. Cover & 47,100 sq. ft. & 70,200 sq. ft. & 23,100 sq. ft. \\
\hline Building coverage & 5,800 sq. $\mathrm{ft}$. & $5,800 \mathrm{sq} . \mathrm{ft}$. & \\
\hline Paving coverage & 34,389 sq. $\mathrm{ft}$. & 21,500 sq. ft. & $-12,620$ sq. ft.* \\
\hline Road & 24,660 & 10,300 & $-13,860$ sq. $\mathrm{ft}$ \\
\hline Parking & 9,720 sq. ft. & 10,800 & $+1,080$ sq. $\mathrm{ft}$ \\
\hline Vehicular stops & 1 & 1 & \\
\hline Vehicular yields & 0 & 0 & \\
\hline Traffic lights & 0 & 0 & \\
\hline Vegetation retained & .5 Acre & 1. Acre & .5 Acre \\
\hline Stowm sewer & 80 I.f. & 40 l.f. & -40 I.f. * \\
\hline Sanitary sewer & $920 \mathrm{lf}$ & 570 l.f. & -350 I.f. * \\
\hline Water & 550 l.f. & 300 l.f. & -250 I.f. * \\
\hline Solar impact-Summer & $2,000 \mathrm{sq} . \mathrm{ft}$. wall & 860 sq. ft. wall & $-1,140$ sq. ft. wall * \\
\hline Solar impact-Winter & 1,160 sq. ft. wall & 1,300 sq. ft. wall & +140 sq. ft. wall * \\
\hline Summer breezes & 2,160 sq. ft. wall & 500 sq. ft. wall & $-1,660$ sq. ft. wall * \\
\hline Winter winds & 2,160 sq. ft. wall & 1,550 sq. ft. wall & - 610 sq. ft. wall * \\
\hline Summer shade & $1,160 \mathrm{sq} . \mathrm{ft}$. wall & 1,300 sq. ft. wall & +140 sq. ft. wall \\
\hline Winter shade & 116 lin. ft. wall & 130 lin. ft. wall & $+\quad 14$ lin. ft. wall \\
\hline
\end{tabular}

Figure 33. Energy Plan - Solar Impact - Summer

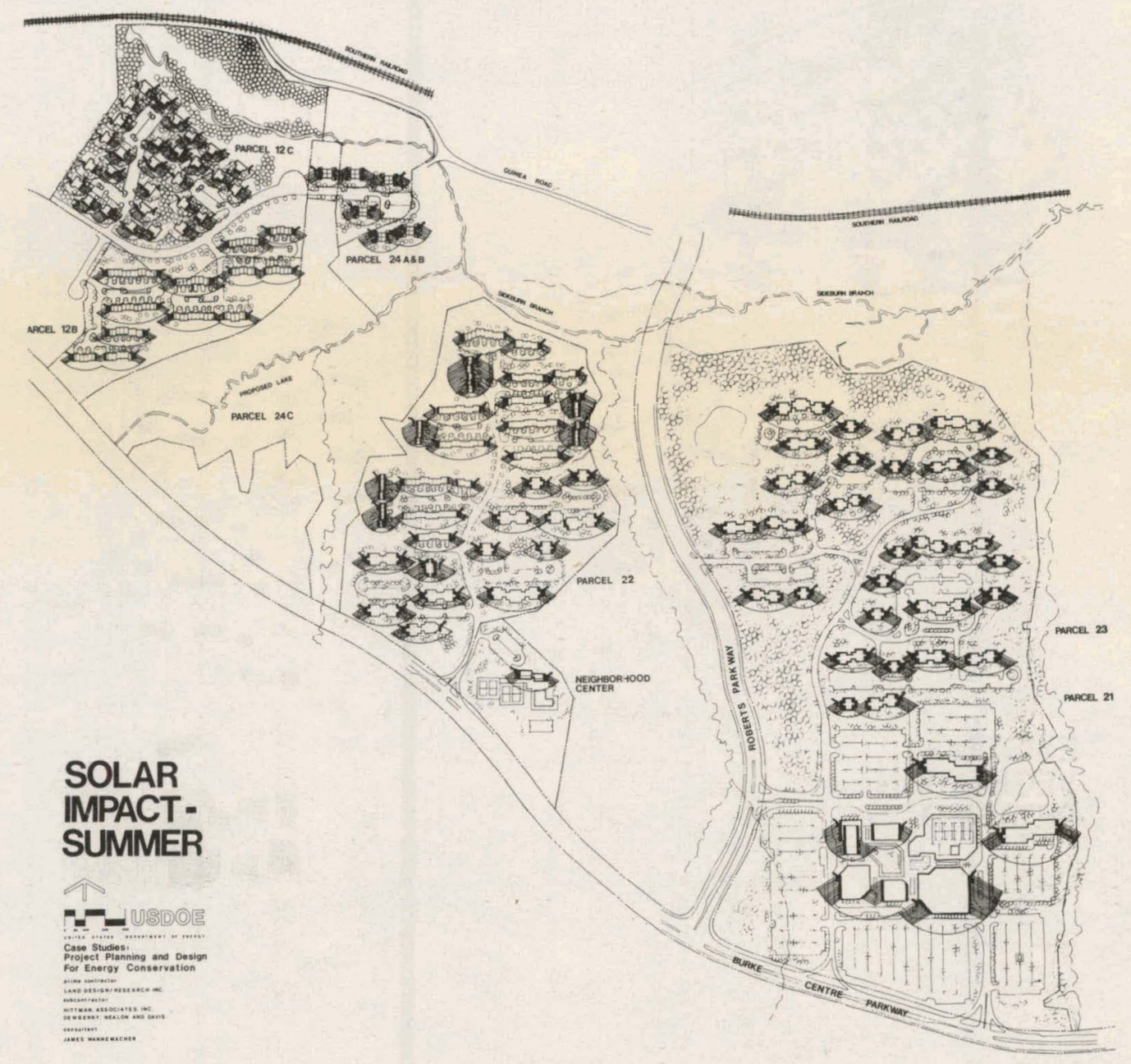




\begin{tabular}{|c|c|c|c|}
\hline & Base Plan & Energy Plan & Difference* \\
\hline Units & 100 townhouses & 100 townhouses & \\
\hline Parking spaces & 231 & 155 & \\
\hline Ratio: spaces/unit & 2.31 spaces/unit & 1.55 spaces/unit & \\
\hline Building coverage & 100,000 sq. ft. & 100,000 sq. ft. & \\
\hline Paving coverage & 96,780 sq. ft. & 109,710 sq. ft. & 12,930 sq. ft. \\
\hline Road & 55,200 sq. $\mathrm{ft}$. & 60,760 sq. ft. & $+5,560 \mathrm{sq} . \mathrm{ft}$. \\
\hline Parking & 41,580 sq. ft. & 48,950 sq. ft. & $+7,370$ sq. ft. \\
\hline Vehicular stops & 3 & 1 & -2 \\
\hline Vehicular yields & 3 & 2 & -1 \\
\hline Traffic lights & 0 & 0 & \\
\hline Vegetation retained & 39,000 sq. ft. & 90.000 sq. ft. & $+51,000$ sq. ft. * \\
\hline Storm sewer & 1,135 lin. $\mathrm{ft}$. & 725 lin. ft. & -410 lin. $\mathrm{ft}$. \\
\hline Sanitary sewer & 7,835 lin. ft. & 6,200 lin. ft. & $-1,635$ lin. ft. \\
\hline Water & 2,336 lin. ft. & 2,790 lin. ft. & +454 lin. $\mathrm{ft}$. \\
\hline $\begin{array}{l}\text { Solar impact-Summer } \\
\text { (east/west exposure) }\end{array}$ & 54,760 sq. ft. wall & 19,200 sq. ft. wall & $-35,560$ sq. ft. wall * \\
\hline $\begin{array}{l}\text { Solar impact-Winter } \\
\text { (south exposure) }\end{array}$ & 27,720 sq. ft. wall & 40,000 sq. ft. wall & $+12,280$ sq. ft. wall * \\
\hline $\begin{array}{l}\text { Summer breezes } \\
\text { (west exposure) }\end{array}$ & 29,700 sq. ft. wall & 8,000 sq. ft. wall & $-21,700$ sq. ft. wall * \\
\hline $\begin{array}{l}\text { Winter winds } \\
\text { (northwest exposure) }\end{array}$ & 28,120 sq. ft. wall & $30,000 \mathrm{sq} . \mathrm{ft}$. wall & $+1,880$ sq. ft. wall \\
\hline Summer shade & 9,840 sq. ft. wall & 40,000 sq. ft. wall & $+30,160$ sq. ft. wall \\
\hline
\end{tabular}

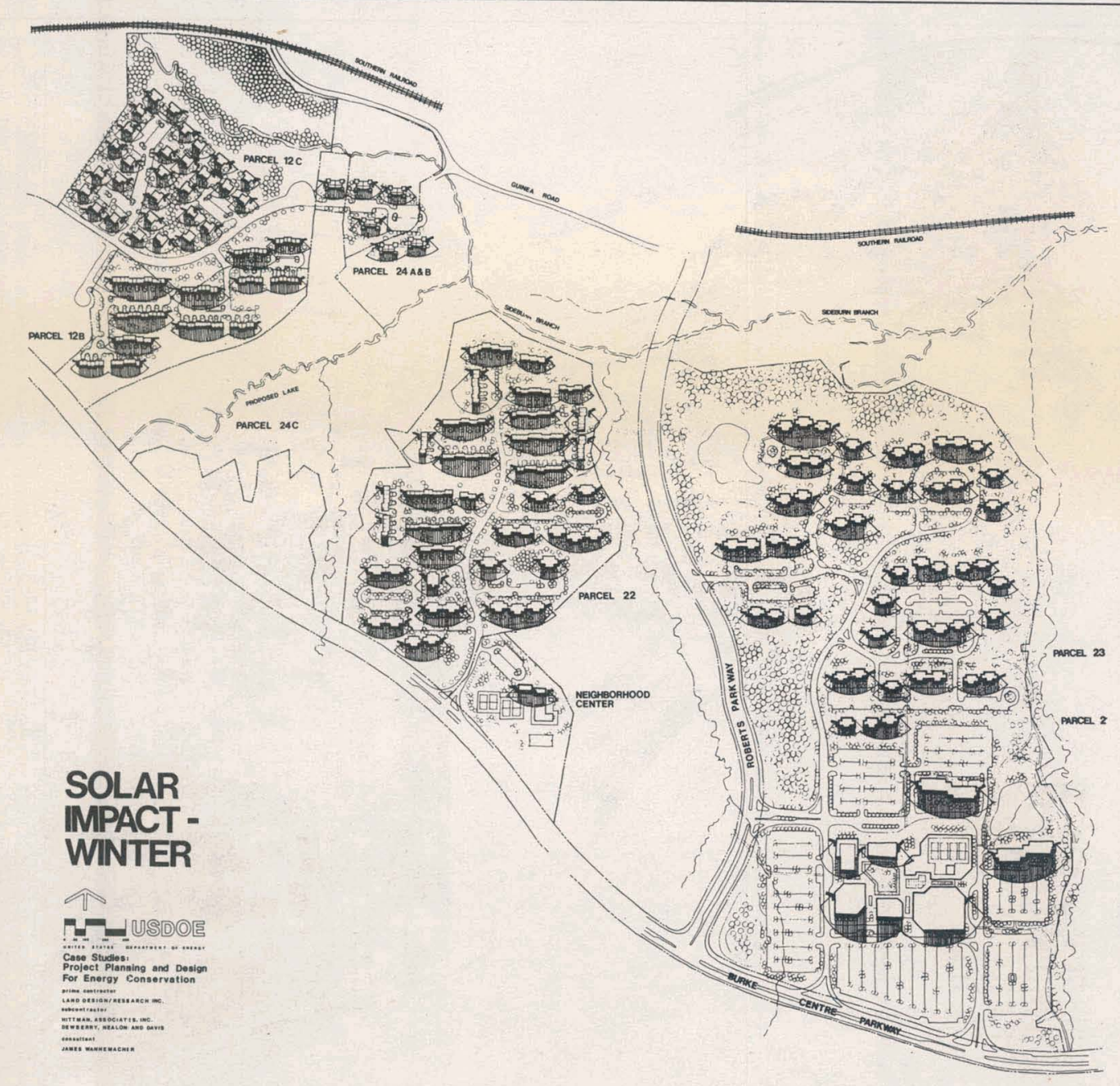




\begin{tabular}{|c|c|c|c|}
\hline & Base Plan & Energy Plan & Difference* \\
\hline Units & 116-four-plexes & 116-four-plexes & - \\
\hline Parking spaces & 269 & 254 & -15 \\
\hline Ratio: spaces/unit & 2.32 spaces/unit & 2.2 spaces/unit & \\
\hline Building coverage & 82,360 sq. ft. & 82,360 sq. $\mathrm{ft}:$ & - \\
\hline Paving coverage & 109,620 sq. ft. & 75,558 sq. ft. & $-34,062$ sq. ft. * \\
\hline Road & 26,400 sq. ft. & 12,000 sq. ft. & $-14,400$ sq. ft. * \\
\hline Parking & 83,220 sq. $\mathrm{ft}$. & 63,558 sq. ft. & $-19,662$ sq. ft. * \\
\hline Vehicular stops & 5 & 3 & $-2^{*}$ \\
\hline Vehicular yields & 0 & 0 & - \\
\hline Traffic lights & 0 & 0 & - \\
\hline Vegetation retained & 178,000 sq. ft. & 222,300 sq. ft. & $+44,300$ sq. $\mathrm{ft}$. \\
\hline Storm sewer & 1,628 lin. ft. & 1,860 lin. ft. & +232 lin. ft. \\
\hline Sanitary sewer & 4,310 lin. ft. & 4,520 lin. $f t$. & +210 lin. $\mathrm{ft}$ \\
\hline Water & 3,875 lin. ft. & 3,495 lin. $\mathrm{ft}$. & -380 lin. ft. \\
\hline $\begin{array}{l}\text { Solar impact-Summer } \\
\text { on east/west walls }\end{array}$ & 40,404 sq. ft. wall & 39,423 sq. ft. wall & 1,071 sq. ft. wall * \\
\hline $\begin{array}{l}\text { Solar impact-Winter } \\
\text { south }\end{array}$ & 25,483 sq. ft. wall & 25,534 sq. ft. wall & 51 sq. ft. wall * \\
\hline $\begin{array}{l}\text { Summer breezes } \\
\text { west }\end{array}$ & 14,280 sq. ft. wall & 15,113 sq. ft. wall & 833 sq. ft. wall * \\
\hline $\begin{array}{r}\text { Winter winds } \\
\text { north west }\end{array}$ & 6,052 sq. ft. wall & 3,468 sq. ft. wall & 2,584 sq. ft. wall * \\
\hline Summer shade & 25,3132 sq. ft. wal & 30,124 sq. ft. wall & $+4,811$ sq. ft. wall * \\
\hline
\end{tabular}

Figure 35. Energy Plan - Prevailing Winter Winds

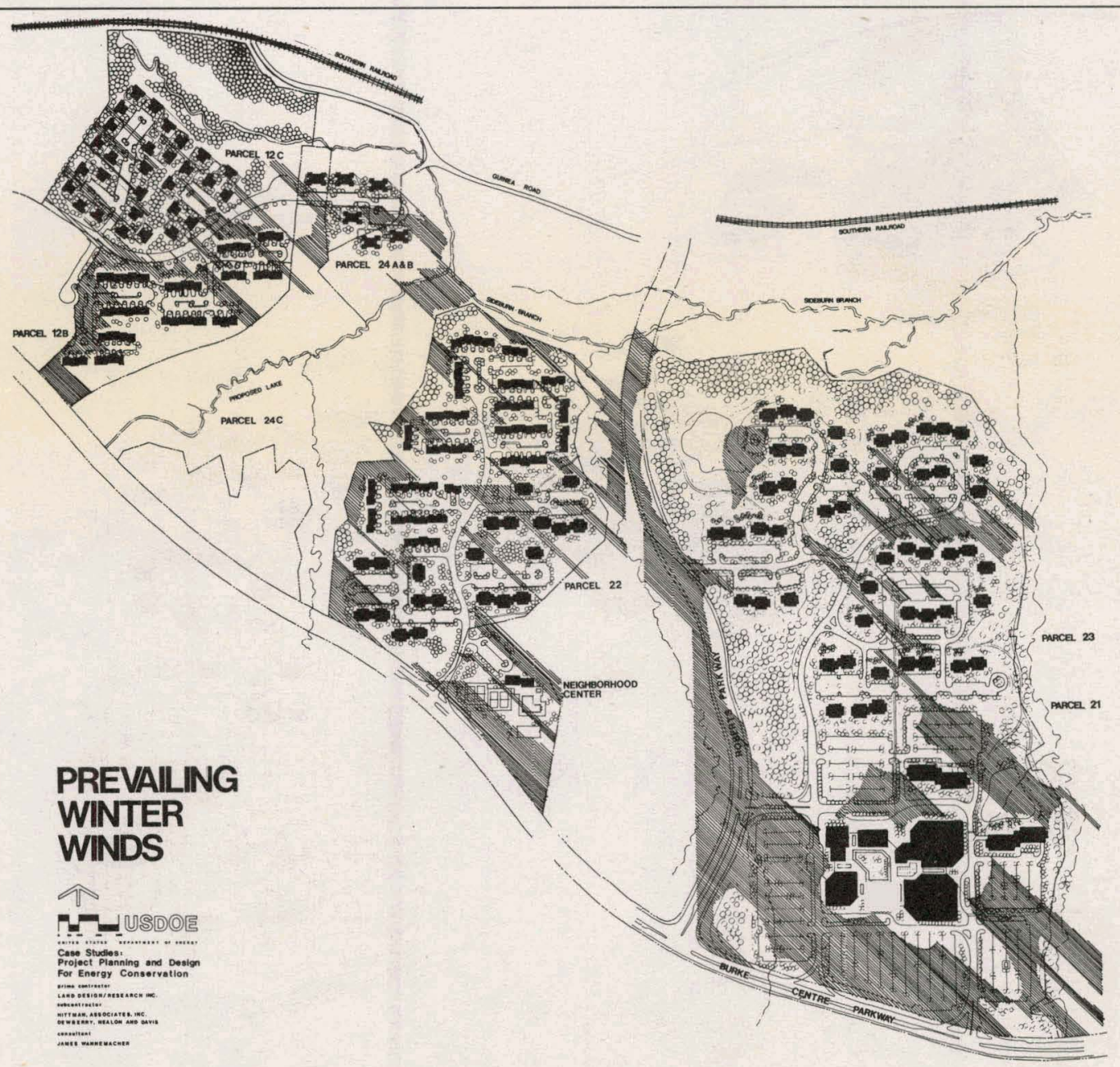




\begin{tabular}{|c|c|c|c|}
\hline & Base Plan & Energy Plan & Difference* \\
\hline Units & 48 cluster units & 48 cluster units & \\
\hline Parking spaces & 104 & 92 & \\
\hline Ratio: spaces/unit & 2.16 spaces/unit & 1.92 spaces/unit & \\
\hline Building coverage & 23,928 sq. ft. & 23,928 sq. ft. & \\
\hline Paving coverage & 41,520 sq. ft. & 36,524 sq. ft. & $-4,996$ sq. ft. * \\
\hline Road & 10,800 sq. ft. & 10,800 sq. ft. & \\
\hline Parking & 30,720 sq. ft. & 25,724 sq. ft. & $-4,996$ sq. ft. * \\
\hline Vehicular stops & 0 & 0 & \\
\hline Vehicular yields & 2 & 0 & $-2^{*}$ \\
\hline Traffic lights & 0 & 0 & \\
\hline Vegetation retained & 66,000 sq. ft. & 90,000 sq. ft. & $+24,000$ sq. ft. * \\
\hline Storm sewer & 395 lin. ft. & 225 lin. ft. & +170 lin. ft. \\
\hline Sanitary sewer & 1,490 lin. $\mathrm{ft}$. & 1,250 lin. $\mathrm{ft}$ & -240 lin. $\mathrm{ft}$ \\
\hline Water & 1,130 lin. $\mathrm{ft}$ & 790 lin. ft. & -340 lin. $\mathrm{ft}$ \\
\hline Solar impact-Summer & 19,108 sq. ft. wall & 12,648 sq. ft. wall & 6,460 sq. ft. wall \\
\hline Solar impact-Winter & 10,608 sq. ft. wall & 9,452 sq. ft. wall & 1,156 sq. ft. wall \\
\hline Summer breezes & 7,582 sq. ft. wall & 4,216 sq. ft. wall & 3,366 sq. ft. wall \\
\hline Winter winds & 13,192 sq. ft. wall & 3,145 sq. ft. wall & 10,047 sq. ft. wall * \\
\hline Summer shade & 10,608 sq. ft. wall & 9,452 sq. ft. wall & - 156 sq. ft. wall \\
\hline
\end{tabular}

Figure 36. Energy Plan - Summer Breezes

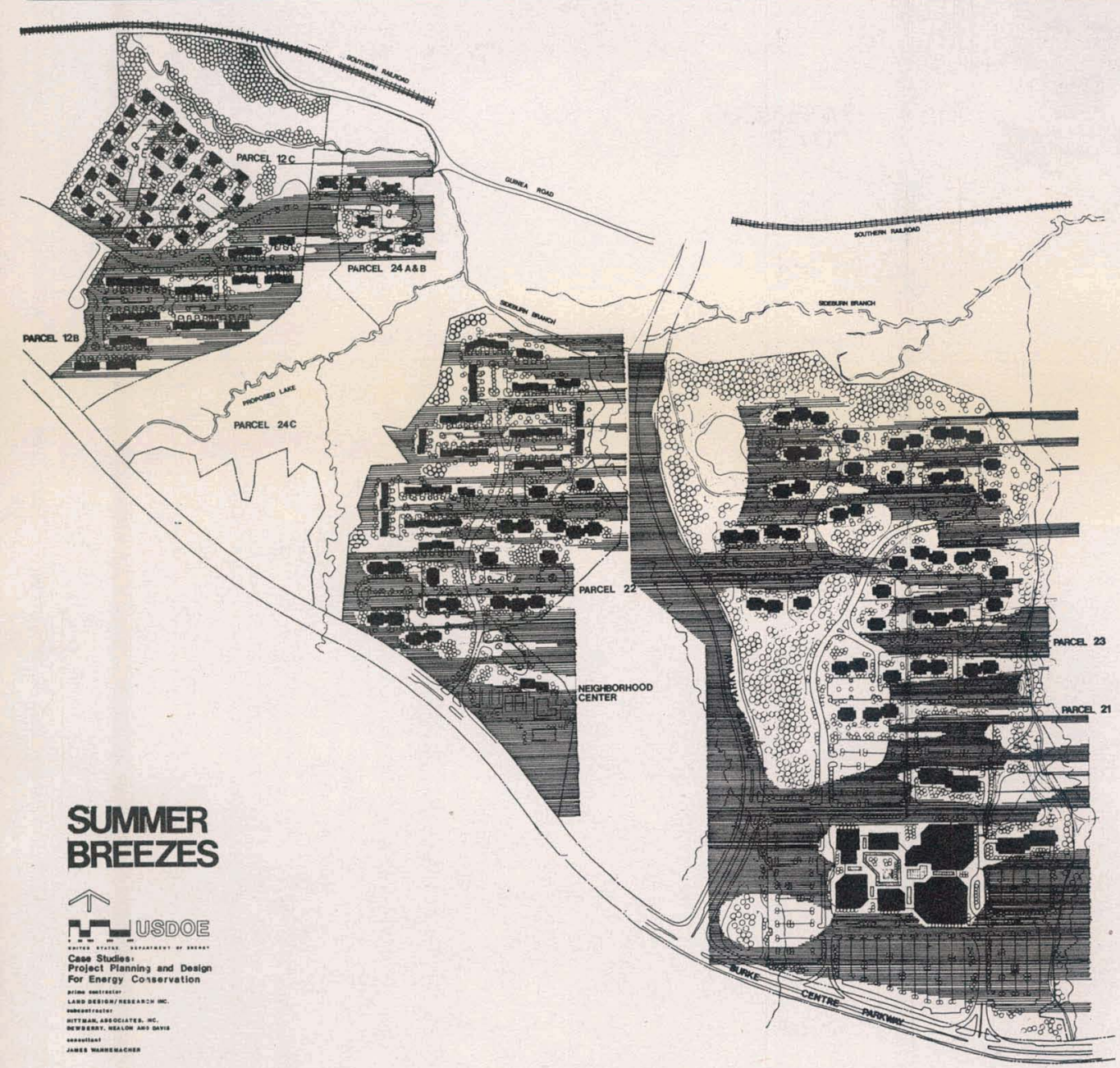




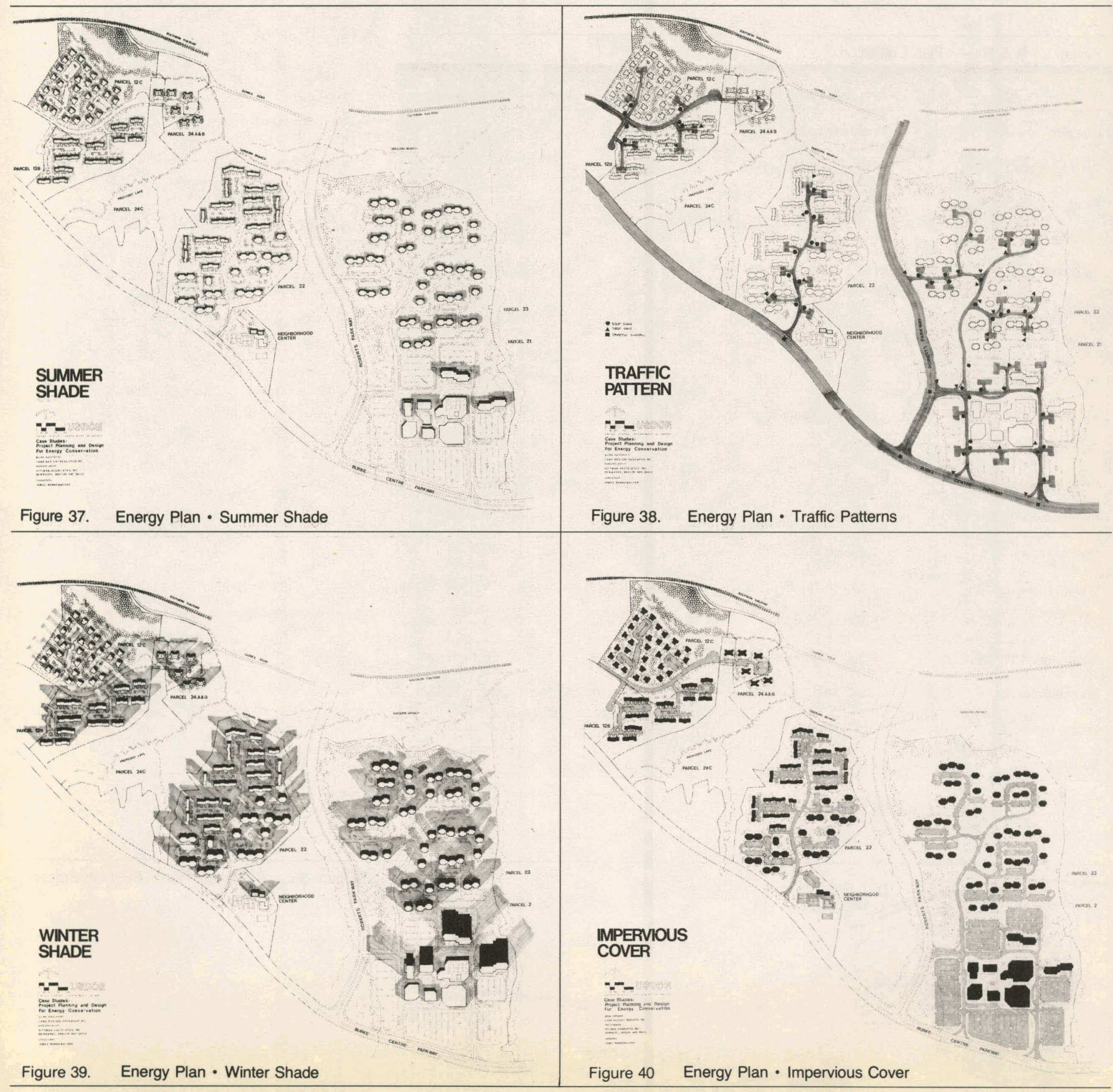




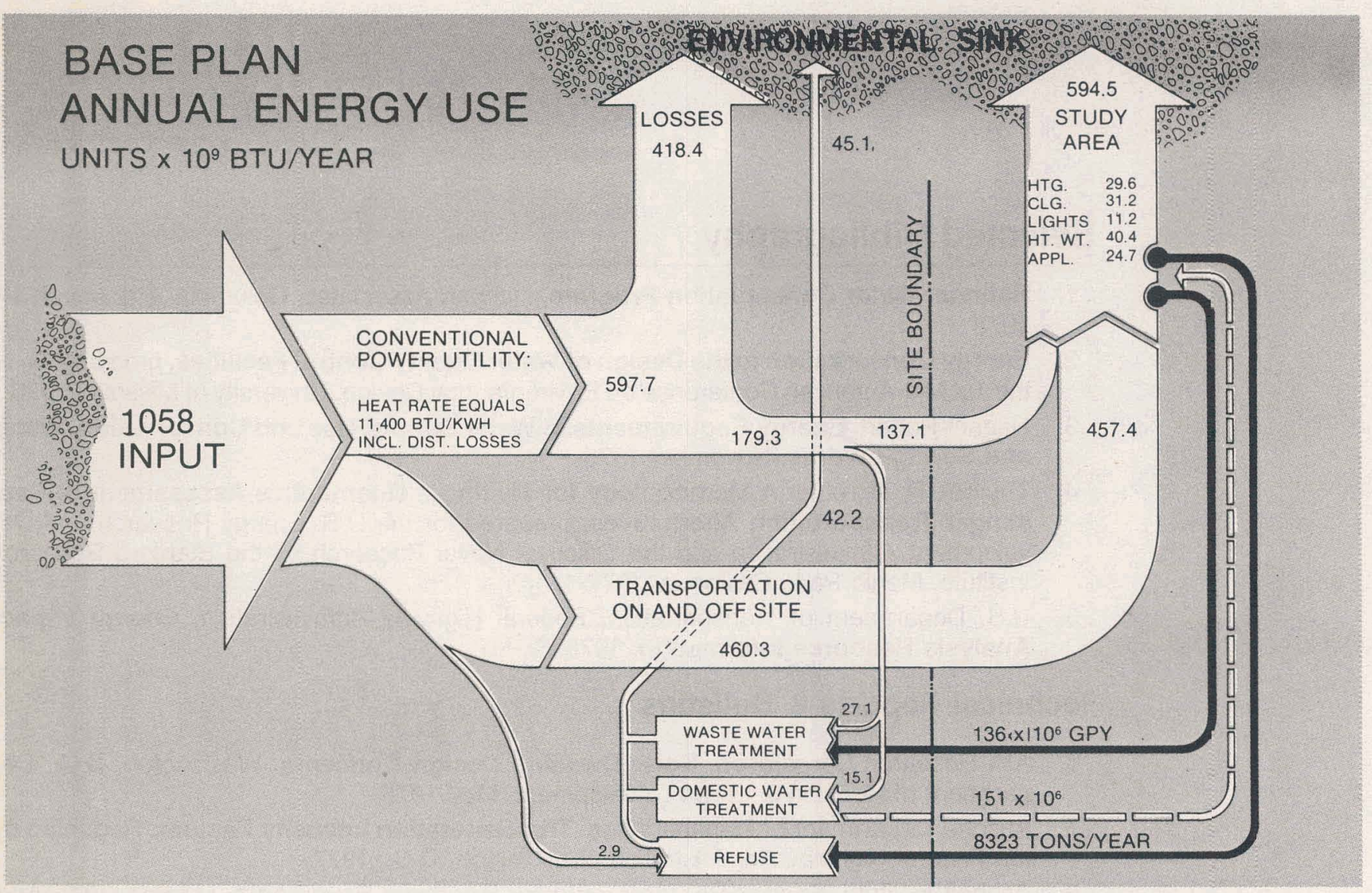

Figure 41 Base Plan - Annual Energy Use

\section{Energy Conservation Plan Energy Use}

\begin{tabular}{|c|c|c|}
\hline & Annual Site Energy Use & $\begin{array}{l}\% \text { of } \\
\text { Total }\end{array}$ \\
\hline $\begin{array}{l}\text { HVAC, Lighting, Appliances, } \\
\text { Well Pumps, and Hot Water: }\end{array}$ & $94.2 \times 10^{9} \mathrm{Btu} / \mathrm{yr}$ & $16.0 \%$ \\
\hline Transportation: & $\begin{array}{r}93.4 \times 10^{9} \mathrm{Btu} / \mathrm{yr} . \\
355.3 \times 10^{9} \mathrm{Btu} / \mathrm{yr} .\end{array}$ & $\begin{array}{l}16.0 \% \\
63.0 \%\end{array}$ \\
\hline Potable Water Treatment: & $8.6 \times 10^{9} \mathrm{Btu} / \mathrm{yr}$. & $2.0 \%$ \\
\hline Wastewater Treatment: & $15.5 \times 10^{9} \mathrm{Btu} / \mathrm{yr}$. & $3.0 \%$ \\
\hline Refuse Collection and Disposal: & $1.7 \times 10^{9}$ Btu/yr. & $<1.0 \%$ \\
\hline $\begin{array}{l}\text { Total Energy Conserving Plan } \\
\text { Energy Use: }\end{array}$ & $568.7 \times 10^{9} \mathrm{Btu} / \mathrm{yr}$. & $100.0 \%$ \\
\hline
\end{tabular}

Base Plan - Annual Energy Use

\begin{tabular}{|c|c|c|}
\hline & Annual Site Energy Use & Total \\
\hline $\begin{array}{l}\text { HVAC, Lighting, Appliances, } \\
\text { and Hot Water }\end{array}$ & $137.1 \times 10^{9} \mathrm{Btu} / \mathrm{yr}$ & $21.0 \%$ \\
\hline $\begin{array}{l}\text { On-site } \\
\text { Off-site }\end{array}$ & $\begin{array}{l}96.2 \times 10^{9} \mathrm{Btu} / \mathrm{yr} . \\
361.2 \times 10^{9} \mathrm{Btu} / \mathrm{yr} .\end{array}$ & $\begin{array}{l}15.0 \% \\
57.0 \%\end{array}$ \\
\hline Potable Water Treatment: & $15.1 \times 10^{9} \mathrm{Btu} / \mathrm{yr}$. & $2.0 \%$ \\
\hline Wastewater Treatment: & $27.1 \times 10^{9} \mathrm{Btu} / \mathrm{yr}$. & $4.0 \%$ \\
\hline Refuse Collection and Disposal: & $2.9 \times 10^{9} \mathrm{Btu} / \mathrm{yr}$. & $1.0 \%$ \\
\hline
\end{tabular}

Total Base Plan Energy Use:

$639.6 \times 10^{9} \mathrm{Btu} / \mathrm{yr}$

$100.0 \%$

\section{E/C PLAN}

ANNUAL ENERGY USE UNITS $\times 10^{\circ}$ BTU/YEAR

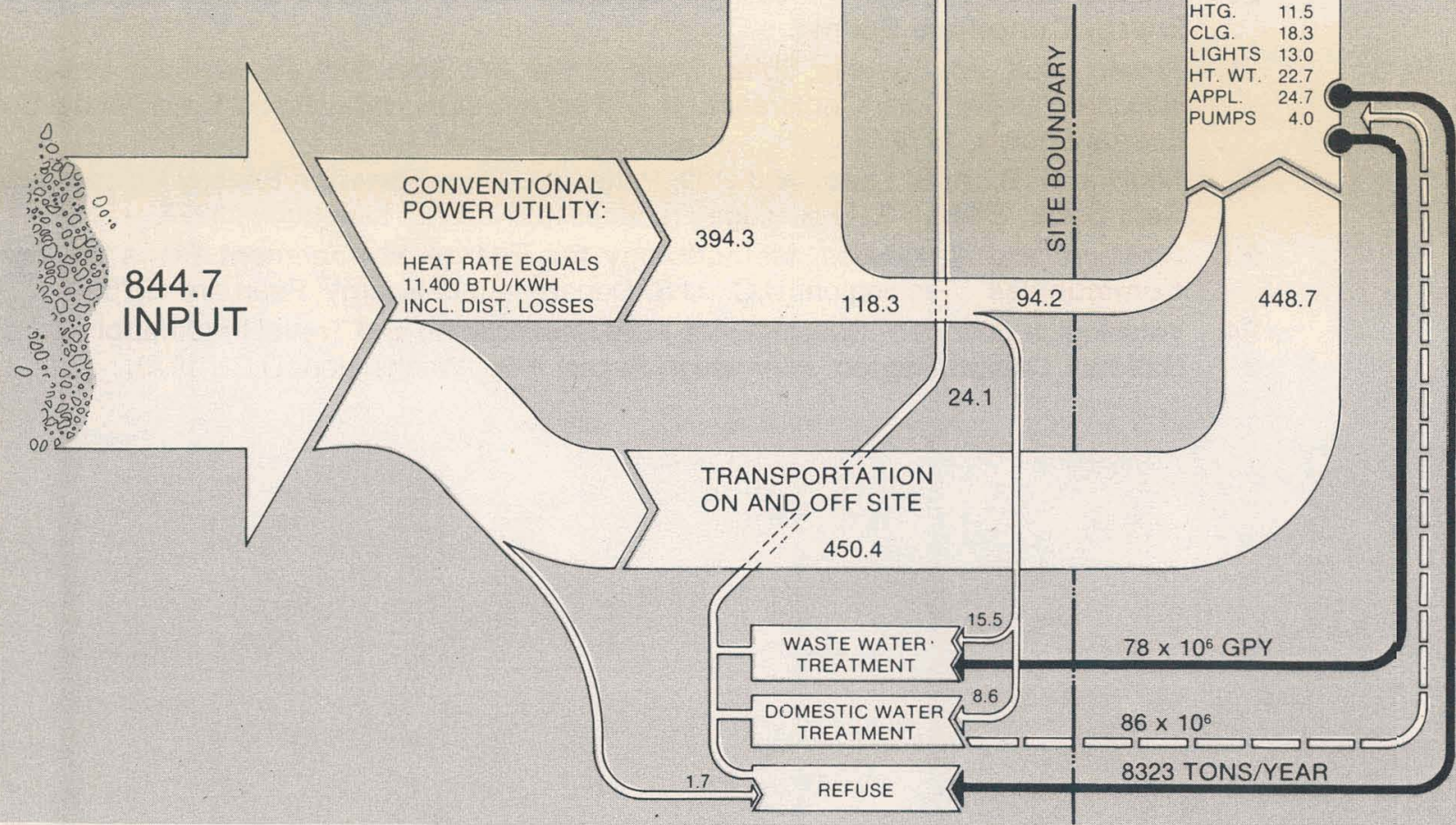




\section{Selected Bibliography}

1. National Water Conservation Program, Hittman Associates, Columbia, Md. March 17, 1978

2. Energy Conservation in the Design of Water Quality Control Facilities, proceedings of the 1st Mid-American Conference on Environmental Design, University of Missouri, 1976.

3. Hagan, Robert, Energy Requirements in Water Supply, Use and Conservation, Water and Sewage Works, November 1976.

4. Thuillier, R. H., et al. A Methodology for Making a Quantitative Assessment of Passenger Transportation Alternatives, prepared for the U.S. Energy Research and Development Administration and the Office of Naval Research by the Stanford Research Institute. Menlo Park, California; 1977.

5. U.S. Department of Transportation, Federal Highway Administration, Energy Impact Analysis Resource Information, 1976.

\section{Technical Reports \& Bulletins}

6. AIA Research Corporation. Solar Dwelling Design Concepts. Washington, D.C., Department of Housing \& Urban Development. May 1976.

7. Arizona Department of Transportation. Trip Generation Intensity Factors. Reprinted by the Federal Highway Administration. Washington, D.C.; 1977.

8. Asphalt Institute. Energy Requirements for Roadway Pavements. M.I.S.C.-73-3. April 1975.

9. Building Officials and Code Administrators, Basic Energy Conservation Code 1978, Second Edition, Chicago, Illinois; B.O.C.A. International Inc. 1978.

10. City of Davis (California) Energy Conservation Ordinance Project. A Strategy for Energy Conservation, 1974.

11. Cote, A. J., Jr., Notes on Residential Solar Heating. Baltimore, Johns Hopkins Applied Physics Laboratory, September 24, 1975.

12. ERDA, Division of Construction, Planning \& Support. Life Cycle Costing, Emphasizing Energy Conservation. Washington, D.C., September 1976, Revised, May 1977.

13. Fairfax County (Va.), Energy Task Force Report, 1978.

14. Hittman Associates. Development of a Simplified Method for Calculating Conduction Heat Loss and Solar Heat Gain through Insulating Glass. Prepared for Architectural Aluminum Manufacturers Association. Hittman Report No. 724, Columbia, Md.; February 1978.

15. Hittman Associates. Energy Utilization Index Method for Predicting Building Energy Use, Vol. II. Prepared for the U.S. Army Construction Engineering Research Laboratory, Hittman Report No. 665, Columbia, Md.; May 1977.

16. Hittman Associates. "Main C,' Computerized Methodology for Evaluation of Municipal Water Conservation Research Programs. HIT-409, Columbia, Md.; August 1969.

17. Institute for Solid Wastes. Municipal Refuse Disposal, American Public Works Association, Public Administration Service; Chicago, Illinois, 1970.

18. National Environmental Systems Contractors Associates. Manual N - Load Calculation for Commercial Summer \& Winter Air Conditioning.

19. National Oceanic and Atmospheric Administration. Local Climatological Data, 1976, Washington, D.C./Dulles International Airport.

20. National Solar Heating \& Cooling Information Center. Passive Design Ideas for the Energy Conscious Builder.

21. Prowler, Don, ed. Passive Solar, State of the Art, Vols. I-III. Proceedings of the 2nd National Passive Solar Conference, U. of Pennsylvania, Philadelphia. International Solar Energy Society, 1978.

22. Shonka, D. B., A. S. Loebl, and P. D. Patterson. Transportation Energy Conservation Data Book: Edition 2. Oak Ridge (Tennessee) National Laboratory, 1977.

23. Sizemore and Associates. Methodology for Energy Management Plans for Small Communities. Washington, D.C.; U.S. Department of Energy; February 1978.

24. Washington Council of Governments. Fuel Restrictions and Travel Implications for the National Capital Region. Information Report \#60. Washington, D.C.; 1973. 


\section{Books}

25. Dantzig, Gecrge B. and Saaty, Thomas L. Compact City, a Plan for a Liveable Urban Environment. San Francisco; W. H. Freeman \& Co., 1973.

26. McClenon, Charles, Ed. Landscape Planning for Energy Conservation. Reston, Virginia; Environmental Design Press, 1977.

27. Olgyay, Victor. Design with Climate. Princeton, New Jersey; Princeton University Press, 1963.

28. Robinette, Gary O. Plants/People/and Environmental Quality. Washington, D.C.; Department of the Interior. National Park Service, 1972.

\section{Articles}

29. "Energy," Buider (Entire Issue), Vol. 1, No. 22., 2 October 1978.

30. "Energy, Coping with the Crunch," Washington Post, 17 September 1978.

31. "Let the Sun Shine In," AE Concepts, No. 25, Jan.-Feb. 1979.

32. Jefferies, Gail. "Atria North, A New Design for Low Rise Offices." Canadian Office, Vol. 9 , No. 10, October 1978.

33. Zanetto, James. "The Location and Selection of Trees for Solar Neighborhoods," Landscape Architecture, Vol. 68, No. 6, November 1978.

\section{Laws \& Ordinances}

34. City of Davis (Calif.). Ordinance No. $\mathbf{7 8 4}$ - Energy Conservation for Residential Construction. 1975.

35. Fairfax County (Va.). Comprehensive Plan, 1975, as amended 1977.

36. Fairfax County (Va.). Zoning Ordinance adopted 12 June 1978.

37. U.S. Government. Public Law 94-385; Energy Conservation and Production Act, 14 August 1976.

\section{Miscellaneous}

38. Personal consultation with Fairfax County (Va.) Waste Management Authority. 